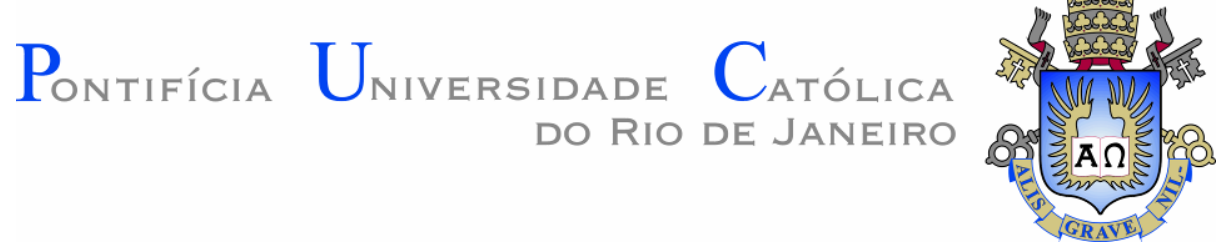

Júlio Cezar Russo Pinto da Silva

Comportamento Oportunista e Renegociação em Parcerias Público-Privadas: Uma Abordagem por Mecanismos de Incentivos

Tese de Doutorado

Tese apresentada como requisito parcial para obtenção do grau de Doutor pelo Programa de PósGraduação em Engenharia de Produção da PUCRio.

Orientador: Prof. Fernando Luiz Cyrino Oliveira

Rio de Janeiro Novembro de 2017 


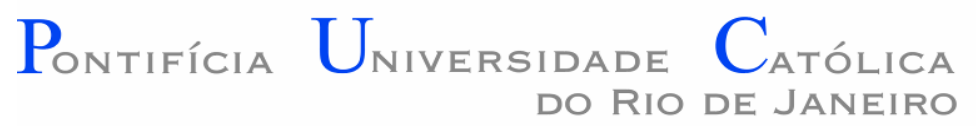

Júlio Cezar Russo Pinto da Silva

\title{
Comportamento Oportunista e Renegociação em Parcerias Público-Privadas: Uma Abordagem por Mecanismos de Incentivos
}

\begin{abstract}
Tese apresentada como requisito parcial para obtenção do grau de Doutor pelo Programa de Pós-Graduação em Engenharia de Produção da PUC-Rio. Aprovada pela Comissão Examinadora abaixo assinada.
\end{abstract}

Prof. Fernando Luiz Cyrino Oliveira

Orientador

Departamento de Engenharia Industrial PUC-Rio

Prof. Marco Antonio Guimarães Dias Departamento de Engenharia Elétrica PUC-Rio

Prof. Luiz Eduardo Teixeira Brandão Departamento de Administração PUC-Rio

Prof. André Barreira da Silva Rocha Departamento de Engenharia Industrial PUC-Rio

Prof. Jorge Cláudio Cavalcante de Oliveira Lima Banco Nacional de Desenvolvimento Econômico e Social - BNDES

Prof. Léo da Rocha Ferreira Departamento de Ciências Econômicas UERJ

Márcio da Silveira Carvalho Coordenador Setorial do Centro

Técnico Científico - PUC-Rio

Rio de Janeiro, 24 de Novembro de 2017 
Todos os direitos reservados. É proibida a reprodução total ou parcial do trabalho sem autorização da universidade, do autor e do orientador.

\section{Júlio Cezar Russo Pinto da Silva}

Economista pela UFRRJ em 2004 e mestre em Economia pela UERJ (2008). É professor adjunto no departamento de Ciências Econômicas da Universidade Federal Rural do Rio de Janeiro pela área de Econometria desde 2009. Foi coordenador do curso de Ciências Econômicas na mesma instituição.

Ficha Catalográfica

Silva, Júlio Cezar Russo P. da

Comportamento oportunista e renegociação em parcerias público-privadas: uma abordagem por mecanismos de incentivos / Júlio Cezar Russo Pinto da Silva; orientador: Fernando Luiz Cyrino Oliveira. - 2017.

81 f.: il. color. ; $30 \mathrm{~cm}$

Tese (Doutorado) - Pontifícia Universidade Católica do Rio de Janeiro, Departamento de Engenharia Industrial.

Inclui bibliografia

1. Engenharia Industrial - Teses. 2. Jogo de screening monopolista. 3. Mecanismos de incentivos. 4. Gestão de PPP. 5. Comportamento oportunista. 6. Modelo agente principal. I. Oliveira, Fernando Luiz Cyrino. II. Pontifícia Universidade Católica do Rio de Janeiro. Departamento de Engenharia Industrial. III. Título 


\section{Agradecimentos}

A minha família

A Glaudiane Lilian de Almeida

Ao Professor Carlos Patrício Samanez (em memória) orientador inicial.

Ao Prof. Marco Antonio Guimarães Dias pela dedicação e paciência.

Ao Prof. Fernando Luiz Cyrino de Oliveira, pelo apoio e presteza na fase final do doutorado.

Ao Prof. Luiz Eduardo Teixeira Brandão do IAG/PUC-RIO

Ao Prof. André Barreira da Silva Rocha do DEI/PUC-RIO

Aos Professores e amigos do DEI/PUC-RIO e do IAG/PUC-RIO

Aos Funcionários do DEI/PUC-RIO

Agradeço, por fim, o suporte da CAPES 


\section{Resumo}

Silva, Júlio Cezar Russo Pinto da; Cyrino Oliveira, Fernando Luiz.(Orientador). Comportamento Oportunista e Renegociação em Parcerias Publico-Privadas: Uma Abordagem por Mecanismos de Incentivos. Rio de Janeiro, 2017. 81 p. Tese de Doutorado - Departamento de Engenharia Industrial, Pontifícia Universidade Católica do Rio de Janeiro.

A estrutura de contratos de Parcerias Público-Privadas (PPP) tem como característica o compartilhamento de riscos do projeto entre o governo e investidor. PPPs têm longo prazo de maturação, volumes elevados de investimentos iniciais e incerteza quanto às receitas. O comportamento futuro de agentes públicos e privados pode transmitir um risco adicional, tornando projetos pouco atrativos quando informações relevantes não ficam evidentes em um contrato. A teoria dos jogos tem sido um instrumento amplamente utilizado para trazer soluções analíticas quando o problema de assimetria de informação está presente. Portanto, este trabalho utiliza os conceitos de teóricos de mecanismos compatíveis com incentivos para PPPs objetivando: (i) aprimoramento de falhas contratuais ex-post via condições ex-ante ; (ii) aprimorar um modelo de jogo de renegociação de PPPs, mostrando como o comportamento oportunista pode ser evitado. Analisa-se o processo de concessão do Complexo Maracanã, como caso ilustrativo via uso de proposições, lemas e teoremas, mostrando que o edital do Governo do Estado do Rio de Janeiro é sub-ótimo do ponto de vista da Teoria de Desenho de Mecanismos.

\section{Palavras-chave}

Jogo de screening monopolista; mecanismos de incentivos; gestão de PPP; comportamento oportunista; modelo agente - principal. 


\section{Abstract}

Silva, Júlio Cezar Russo Pinto da; Cyrino Oliveira, Fernando Luiz. (Advisor). Opportunistic Behavior and Renegotiation in Public-Private Partnerships: An Incentive Mechanism Approach. Rio de Janeiro, 2017. 81 p. Tese de Doutorado - Departamento de Engenharia Industrial, Pontifícia Universidade Católica do Rio de Janeiro.

The Public-Private Partnerships (PPP) contract structure is characterized by the sharing of project risks between the government and the investor. PPPs have long maturation maturities, high initial investment volumes and revenue uncertainty. The future behavior of public and private agents may carry an additional risk, making projects unattractive when relevant information is not evident in a contract. Game theory has been a widely used instrument to provide analytical solutions when the problem of information asymmetry is present. Therefore, this thesis uses the concepts of mechanism theorists compatible with incentives for PPPs, aiming: (i) improvement of ex-ante and ex-post contractual failures; (ii) to improve a PPP renegotiation game model, showing how opportunistic behavior can be avoided. It analyzes the concession process of the Maracanã Complex as illustrative case via use of propositions, lemmas and theorems, showing that the State Government's announcement of Rio de Janeiro is sub-optimal from the point of view of the mechanisms of Design Theory.

\section{Keywords}

Monopolist screening game; incentive mechanisms; PPP management; opportunistic behavior; principal - agent model. 


\section{Sumário}

$\begin{array}{ll}\text { 1.Introdução } & 10\end{array}$

$\begin{array}{ll}\text { 1.1Objetivos e organização da tese } & 13\end{array}$

2.Revisão de Literatura 15

2.1. Contratos com assimetria: Problema Principal-Agente 15

$\begin{array}{ll}\text { 2.2. Renegociação e fatores críticos nas PPPs } & 18\end{array}$

3. Fundamentação Teórica 20

3.1. Modelo Agente - Principal 20

3.1.1 O estado do investidor $\theta$ é observável 23

3.1.2 O estado $\theta$ observado somente pelo Investidor 26

4. Analise de caso: Complexo Maracanã 36

4.1. Contexto 36

$\begin{array}{ll}\text { 4.2. Movimentos oportunistas } & 37\end{array}$

5. Modelo de Ho para Renegociação de PPPs 41

5.1. Analise do Equilíbrio de Nash no Jogo de PPP 43

5.2. Custo Político caso o governo jogue "Negociar". 45

5.3. Custo Político caso o governo jogue "Rejeitar". 45

5.4. Refinamento do Equilíbrio de Nash $\quad 47$

6. Mecanismos de Incentivos e o Modelo de Renegociação 50

6.1. Contexto para renegociações de PPPs 50

6.2. Abertura de renegociação: o investidor selecionado 52

6.3. Formação do ENPS Bayesiano na Renegociação 59

6.4. Renegociação do Complexo Maracanã 66

7. Conclusões 69

7.1. Análise e contribuições do estudo 69 
7.2. Implicações para políticas públicas.

7.3. Limitações e pesquisa futura.

8. Referências bibliográficas

Apêndice 1 - Maximização do Governo com Restrições de Incentivos 79

Apêndice 2 - Características Parâmetros da PPP de Ho 80 


\section{Lista de Figuras e Tabelas}

Figura 1- Par ótimo $\left(R_{i}^{*}, e_{i}^{*}\right)$ para o estado $\theta_{i}$ quando observável 25

Figura 2 - Contrato ótimo para $\theta_{L}$ e $\theta_{H}$ na PPP com estado observável 25

Figura 3 - Indiferença entre o ponto $\left(e_{L}, R_{L}\right)$ e $f\left(R-c\left(e, \theta_{H}\right)=\pi_{H} \quad 30\right.$

Figura 4 - Movimento oportunista do governo nas receitas do projeto $\quad 32$

Figura 5 - Movimento oportunista por parte do investidor 32

Figura 6 - $\left(e_{H}, R_{H}\right)$ e $\left(e_{L}, R_{L}\right)$ não são indiferentes para o investidor. 34

Figura 7- $O$ contrato ótimo tem $e_{L} \leq e_{L}^{*}$

Figura 8 - Um contrato ótimo tem $e_{H}^{*}=e_{H}, \quad 35$

Figura 9 - Alteração contratual do GERJ nas receitas do Maracanã 38

Figura 10 - Movimento Oportunista da Concessionária Maracanã. 38

Figura 11 - Jogo de renegociação da PPP modificado. 43

Figura 12 - Função do custo político de relicitação da PPP 47

Figura 13 - Zona de Oferta de Renegociação 49

Figura 14 - Contrato Gerador de Equilíbrio Separador 53

Figura 15 - Comportamento oportunista de $\theta_{L}$ na PPP 54

Figura 16 - Realização de esforço não sustentável de $\theta_{L}$. 55

Figura 17 - Jogo de Ho com ENPS Bayesiano 65

Tabela 1 - Performance do Complexo Maracanã 67 


\section{1 \\ Introdução}

A partir do final da década de 1980, muitos países latino-americanos enfrentaram uma situação antagônica: dificuldades severas de orçamento público e necessidades de ampliar investimentos em infraestrutura (Giambiagi \& Além, 2016). A saída dos governos locais para resolver tal situação, foi empregar a estrutura de contratos de Parcerias Público-Privadas (PPPs) para alavancar projetos relacionados à energia, rodovias, água e saneamento. As PPPs têm se tornado uma alternativa cada vez mais presente, pois, projetos de infraestrutura são essenciais para aumento da produtividade da economia. Este modelo contratual destina-se a proporcionar um maior bem-estar social e alcançar, ao mesmo tempo, um retorno atraente para os investidores que desejam participar neste arquétipo de projeto.

A maioria das PPP envolve projetos BOT (Build-Operate-Transfer) (Auriol e Picard, 2013). Neste ambiente, o investidor privado constrói e opera o projeto, cobra tarifas e mantém a propriedade durante o período da concessão, após o qual o ativo é devolvido o governo. Sua composição contratual requer um ou mais investidores interessados em oferecer serviços públicos a uma determinada taxa de retorno onde o governo é o concessor. É estabelecido um prazo para a concessão que, após esse período, pode voltar a ser licitada. Tais projetos geralmente envolvem "monopólios naturais". A expectativa quanto aos resultados, é que o investidor privado possa operar o projeto oferecendo boa qualidade e baixas tarifas na prestação de serviços. Para tal, a empresa tem de buscar maior produtividade gerando, portanto, menores custos para viabilizar baixas tarifas. Por parte do setor público é esperado fornecer uma estrutura jurídica que permita ao investidor privado ganhar uma aceitável taxa de retorno sobre o investimento, Moszoro (2013).

O objetivo principal da PPP é prover determinado ativo (obra de infraestrutura, por ex.) ou serviço público com uma qualidade e preço (tarifa) adequado. O compartilhamento dos riscos entre o governo e o investidor privado, o longo prazo de maturação, alto porte de investimentos iniciais e incertezas relativas às receitas são características basilares (Brandão et al., 2012). Além disso, um 
problema adicional pode emergir quando condições contratuais não ficam bem estabelecidas: o comportamento futuro dos participantes do contrato pode se alterar devido à natureza das informações dispostas. Deste modo, o gap de informações pode permitir que os participantes, posteriormente, atuem de modo oportunista, causando conflitos entre as partes e podendo até motivar uma rescisão. De acordo com Moszoro (2013), projetos de PPPs geralmente envolvem situações em que a parte privada possui mais informações sobre situações particulares (custos, restrições operacionais, etc.) ou tecnologias. O setor público sabe que tal condição é uma desvantagem informacional, dada a dificuldade em monitorar constantemente o investidor privado com as principais obrigações contratuais: (i) investimento não observado ex-ante e; (ii) a entrega de qualidade dos serviços prestados ex-post. Neste sentindo, a Teoria dos Jogos se insere como uma ferramenta importante para analisar situações de conflito e/ou cooperação em um contrato onde as informações não são de conhecimento comum entre os participantes. Desenhos contratuais podem diminuir o impacto de alguns dos riscos inerentes ao projeto como: risco de mercado, riscos cambiais e risco de flutuação de receitas.

Laffont e Tirole (1990) destacam que o sistema de incentivos ideal para os principais devem incluir: (i) extração de renda informacional dos agentes; (ii) incentivos apropriados para redução de custos e; (iii) especificação de uma recompensa em relação a tarifa cobrada. Esta estrutura impede que os participantes se comportem de forma oportunista ex-post e, assim, promovam conduta eficiente ex-ante. Ressaltam, adicionalmente, que: (iii) o compromisso total de ambas as partes é um caso idealizado; (iv) os contratos geralmente não são sequencialmente ótimos ou à prova de renegociação, pois, as partes podem melhorar para modificar o contrato inicial. Portanto é possível que, após a assinatura, as partes mudem seu comportamento. No caso das PPPs, a alteração de comportamento impõe um risco adicional ao contrato. A consequência é o desencorajamento dos setores público e privado em ingressar em projetos PPP devido risco do comportamento futuro da outra parte. $\mathrm{O}$ oportunismo do parceiro privado pode vir através da redução do investimento e da qualidade de serviços oferecidos. O oportunismo do governo é oriundo do controle tarifário ou expropriação de ativos.

Ajustes contratuais são adaptações que buscam adequar o contrato às flutuações financeiras negativamente abruptas, saltos na taxa de câmbio, etc. Estes 
cenários adversos podem prejudicar tanto a viabilidade financeira do projeto quanto a prestação de serviços públicos. Os ajustes contratuais entre o governo e investidores objetivam: (i) identificar e corrigir erros operacionais até o momento corrente e; (ii) realizar aprimoramentos contratuais com a finalidade de alcançar melhores parâmetros de prestação de serviços públicos, mantendo a saúde financeira do projeto.

Ferramenta comum utilizada pelos governos tanto nas fases de divulgação de edital quanto na renegociação, os subsídios sinalizam garantias ao investidor privado em casos de mudanças abruptas no cenário econômico e/ou de acontecimentos que alterem os custos operacionais (exemplo: catástrofes naturais). Dentre as medidas muito utilizadas: (i) possível extensão do prazo de concessão (em geral, ex-ante); (ii) suporte financeiro (pode ser ex-ante ou ex-post) e; (iii) redução de parte das obrigações contratuais (essencialmente ex-post) (Project Management Institute, 2000). O subsídio é uma forma do governo, como ofertante monopolista do contrato, sinalizar que o projeto possui um instrumento de diluição de risco para o investidor, em especial, o de mercado. Por outro lado, dependendo da forma como os subsídios são tratados pelo governo, podem-se gerar distorções ex-post. O efeito é a mudança de percepção do investidor privado ao fazer solicitações de subsídios. O investidor pode aumentar a frequência de pedidos ou de volumes financeiros, superando a expectativa do governo no período de ajuste contratual/renegociação. Quando tal situação ocorre, o governo é colocado numa posição que dificilmente nega a renegociação. A consequência do volume de subsídios excessivos são as críticas de má gestão de recursos públicos e suspeitas de corrupção (Ho, 2006).

Tais distorções podem resultar em incentivos equivocados que impulsionam o oportunismo. A primeira distorção, pré-contratual, pode ocorrer no período de licitação. Investidores de baixa capacidade gerencial, atraídos pela política de subsídios, podem se tornar vencedores da licitação, através do bid oportunista. A estratégia do bid oportunista ocorre por superestimação das projeções de receitas ou subestimação dos custos do projeto, tentando recuperar perdas através de posteriores subsídios adicionais (Zhu et al, 2016). O lance oportunista cria uma deformidade no processo de seleção de agentes, pois, caso o investidor selecionado seja de baixa capacidade a possibilidade de haver um processo de renegociação 
aumenta ${ }^{1}$. A segunda distorção é pós-contratual. Falhas no contrato inicial permitem ao investidor diminuir seus esforços na operação e gerenciamento do projeto, mesmo que este investidor tenha alta capacidade produtiva. Deste modo, o subsídio pode ser uma ação sinalizadora ex-ante por parte do governo. Dependendo de como é percebida pelos concorrentes da licitação, o subsídio pode criar incentivos à participação no projeto de investidores não suficientemente capacitados. A consequência, é que a ação do investidor pré-assinatura do contrato influencia diretamente sua ação pós-assinatura, forçando-o a uma negociação com o governo no futuro.

\section{1}

\section{Objetivos e Organização da Tese}

Explicar e analisar a mudança de comportamento dos participantes de um contrato após sua celebração é uma área em constante evolução da Teoria dos Jogos. A questão de pesquisa deste trabalho é responder como a teoria de desenho de mecanismos pode minimizar problemas de falhas contratuais de PPPs ex-post, via condições ex-ante, contribuindo com a literatura de PPPs do seguinte modo: (i) Obter um desenho contratual que permita melhoria na seleção de investidores com maior transparência. O vencedor do processo da licitação deve manter o desempenho compatível através de cláusulas contratuais ex-ante ao longo da vida do projeto; (ii) Analisar os impactos do comportamento oportunista, que pode ocorrer seja pelo lado do governo quanto pelo investidor privado (geração de falha contratual); (iii) Demonstrar como mecanismos de incentivos podem aprimorar a renegociação nas PPPs, evitando possíveis prejuízos ao investidor e significativos custos políticos para o governo.

Este trabalho assim se organiza além deste conteúdo introdutório: O segundo capítulo realiza a revisão de literatura. O terceiro capítulo, seguindo MasColell et al (1995) apresenta as condições iniciais de uma situação pós-contratual do modelo Agente-Principal adaptado às PPPs. Divide-se este capítulo em dois

\footnotetext{
${ }^{1}$ Entretanto, é obrigatório diferenciar as renegociações previstas em contrato que assegurem determinadas garantias ao investidor avesso ao risco de renegociações forçadas por este para garantir compensação para além do acordado anteriormente e que não foram incluídos no contrato inicial.
} 
sub-tópicos: no primeiro, analisa-se um cenário em que as ações são amplamente observáveis (sem assimetria de informações). No segundo, tais condições são alteradas para refletir o cenário em que o estado observável somente pelo investidor. Ainda nesta seção, inserem-se proposições de mecanismos compatíveis com incentivos, mostrando como essas proposições podem minimizar o comportamento oportunista. No quarto capítulo, aplica-se a adaptação teórica à concessão do Complexo Maracanã. O quinto capítulo apresenta as principais configurações do modelo de renegociação de PPPs de Ho (2006). Os fundamentos de mecanismos de incentivos são utilizados no sexto capítulo, fornecendo elementos para aperfeiçoar este modelo através de um Jogo Bayesiano. O último capítulo fornece as conclusões e propostas para aprimoramento deste estudo no futuro. 


\section{2 \\ Revisão da Literatura}

\section{1 \\ Contratos com assimetria: Problema Principal-Agente}

A modelagem de contratos tornou-se uma das aplicações mais utilizadas para minimizar problemas relacionados à assimetria de informações entre as partes de um contrato. Sob a ótica de Teoria dos Jogos (TJ) aplicada a finanças e economia, o estabelecimento de um contrato requer jogadores racionais, maximizadores de valor, que consideram as possíveis estratégias dos demais jogadores, suas estratégias e payoffs. A interação estratégica é essencial na tomada de decisão dos agentes na TJ. A assimetria de informação entre os jogadores ocorre quando um jogador dispõe de mais informações do que outro, podendo alterar o equilíbrio deste jogo.

Um problema agente - principal com assimetria de informação surge sempre que a parte menos informada (o principal) se propõe contratar a parte mais informada (o agente). De acordo com Laffont e Martimort (2002), sempre que os principais delegam a tarefa com um agente com informação privada, pode ocorrer seleção adversa e/ou risco moral. No primeiro caso, pode ser selecionada uma firma de baixa produtividade. No segundo caso, o acompanhamento do contrato é difícil e, após aceitar o contrato, o agente pode tomar uma ação indesejada, como exercer o menor nível de esforço, que pode não ser observável pelo principal.

Nesse contexto, o principal deve oferecer um contrato com os incentivos corretos para extrair informações privadas do agente e conseguir um uso eficiente dos recursos econômicos (Myerson, 1979, 1982). Na teoria dos jogos, o problema agente-principal com a seleção adversa geralmente é modelado como um jogo sequencial, que começa com a natureza escolhendo o tipo do agente (que é revelado de forma particular ao agente). O principal então oferece um contrato take-it-orleave-it para o agente. Na próxima jogada, o agente aceita e executa o contrato ou o recusa. O jogo então termina e os jogadores recebem seus retornos.

A literatura fornece uma extensa análise dos principais problemas de agentes envolvendo informações assimétricas em diferentes relações sociais e econômicas. Hurwicz $(1960,1973)$ introduz a teoria de desenho de mecanismos 
para estudar problemas de informação assimétrica. No modelo, o objetivo do mecanismo é um sistema no qual o indivíduo revela sua informação privada (por exemplo, seus custos privados ou sua produtividade). O trabalho de Rothschild e Stiglitz (1976) relata o problema de seleção adversa presente no mercado de seguros desenhando um contrato no qual o principal (seguradora) extrai a informação dos agentes (segurados) com diferentes perfis de risco gerando um equilíbrio separador.

A Teoria dos Jogos se mostra bem-sucedida em desenhar relações contratuais. Fudenberg e Tirole (1990) realizaram um estudo sobre renegociação contratual em uma estrutura de risco moral. Laffont e Tirole (1990) investigam o impacto da renegociação em contratações públicas num modelo de seleção adversa de dois períodos com comprometimento e renegociação. Hart e Moore (1988) analisam o contrato ótimo em dois casos. Primeiro, quando um contrato está sendo usado para facilitar o comércio entre dois agentes, que devem realizar investimentos específicos a essa relação, geralmente não é possível implementar a condição first-best, resultando em sub-investimento. No segundo caso, eles analisam um contrato de compartilhamento de riscos, sem investimentos específicos. O estudo conclui que é possível implementar o first-best desde que as mensagens enviadas entre os agentes possam ser verificadas publicamente. Dewatripont e Maskin (1990) analisaram como desenhar contratos que possam permanecer blindados à renegociação para determinadas situações, fornecendo conceitos basilares dos problemas de renegociação em PPP.

Recentemente, Medda (2007) modelou interações ótimas para jogadores perfeitamente racionais, seu comportamento na alocação de riscos e possíveis problemas associados ao risco moral. Englmaier e Wambach (2010) incorporaram preferências sociais na teoria dos contratos, investigando o problema do risco moral e acrescentam a hipótese de que o agente possui aversão à desigualdade. O estudo conclui que a presença de aversão à desigualdade altera a estrutura de contratos ótimos, levando a convergência para regras de compartilhamento linear. Além disso, oferece uma nova ferramenta de incentivo, já que o agente pode ser recompensado por um bom desempenho. Chang (2014) modela um arranjo do tipo pain-gain para contratos no setor de construção. A pesquisa mostra que, quando o proprietário não leva em conta os riscos de rescisão do contrato, o resultado é que 
os incentivos para que o contratante reduza custos são subutilizados. Wang e Liu (2015) integram a teoria das preferências à equidade com o modelo tradicional agente-principal. $\mathrm{O}$ trabalho calcula incentivos ótimos quando os governos empregam investidores que possuem preferências à equidade. Páez-Pérez e Sánchez-Silva (2016) usaram um modelo de simulação para mostrar as ações sequenciais de interação dinâmica entre entidades públicas e privadas em um sistema de infraestrutura física.

Estudos mais recentes têm usado Teoria dos Jogos e também outras áreas de conhecimento para analisar problemas contratuais na PPP, fornecendo instrumentos para melhorar a relação de negócios entre o governo e o agente privado. Rasmusen (2001) modela um jogo de reintegração de propriedade, demonstrando que o comportamento ineficaz do agente reduz a eficiência do projeto. No entanto, aumenta seu payoff caso a renegociação com o governo seja obtida. O problema de risco moral é evidenciado na PPP do tipo build-operate-transfer (BOT), pois, o investidor participa também como empreiteiro em obras de melhorias e sabendo que o governo sempre sinaliza com subsídios, o investidor não se preocupa com excessos de custos beneficiando-se através do oportunismo.

Ho e Liu (2004) constroem um modelo analítico para estudar o lance oportunista e o construction claims $^{2}$ em projetos de construção. Os resultados indicaram que o Equilíbrio de Nash de um pedido de garantia adicional é negociar e resolver o problema contratual. Ho (2006) descreve através de seu modelo de renegociação, quando e como o governo vai resgatar um projeto problemático ao adotar a estratégia de resgate e quais são impactos em termos de desenho de contratos e gestão de projetos. O estudo também menciona que o problema do oportunismo envolve a informação prévia de que o governo pode socorrer um projeto problemático, conduzindo a dois tipos de oportunismo: o primeiro, précontratual, é o comportamento de licitantes oportunistas na PPP, pois, em seus lances, investidores propositalmente agem subestimando os possíveis riscos envolvidos ou superestimam a rentabilidade do projeto com a finalidade de superar outros investidores; O segundo, pós-contratual, é o do tipo Agente-Principal em que aparece o problema de risco moral.

\footnotetext{
${ }^{2}$ São pedidos de garantias adicionais que visam garantir uma recompensa além do acordado no contrato inicial. Ver Adrian (1993) e Levin (1998).
} 
Moszoro (2013) alia a teoria dos jogos com teoria de opções usando contratos over-the-counter, nos quais o agente público detém uma call que o permite exercer o direito de comprar legalmente o projeto, a um preço préestabelecido, caso o agente privado tenha um comportamento oportunista. Do mesmo modo, o agente privado detém uma put, que pode ser considerada como uma opção de "sair" do projeto, em que o investidor tem o direito de exercê-la, caso o agente público comece a se comportar de forma oportunista. O estudo de Kang et al.(2013) propõe um leilão de primeiro preço de lance selado com valores privados independentes para determinar royalties de equilíbrio e subsídios em PPPs.

\section{2}

\section{Renegociação e Fatores Críticos nas PPPs}

De acordo com Silva Neto et al. (2016), a pesquisa sobre PPPs teve crescimento exponencial nos últimos dez anos. Em sua maioria, concentram esforços em partilha de riscos, análise de valor e desempenho contratual. A bibliometria indica que pesquisas tratando sobre rescisão de contratos e renegociação ainda são incipientes $(2 \%)$. Poucos trabalhos lidam com situações de oportunismo seja, ex-ante: lance superestimado (Ho e Liu, 2004; Ho, 2009) ou ex-

post: mudança de comportamento após assinatura do contrato (Moszoro, 2013) e mecanismos para escolher o melhor investidor.

Guasch et al. (2003) realizaram uma análise econométrica de uma série de concessões na América Latina e concluíram que as características dos contratos, o ambiente regulatório e choques econômicos são fatores determinantes que levam a empresas a pedir renegociação. O estudo avaliou 307 contratos de concessão em cinco países latino-americanos (Argentina, Brasil, Chile, Colômbia e México) entre 1989 e 2000. O estudo conclui que os contratos assinados, particularmente, no setor de transportes (73\%) e nos setores de água e saneamento (52\%), são renegociados em média 3,5 anos após a assinatura do contrato. O trabalho indica que alta incidência de renegociação de contratos, pode levantar descrença sobre a validade do modelo de concessão, comprometendo todos os benefícios gerados pelo processo de licitação. Nessa fase, o investidor tem influência expressiva, porque o governo, em geral, é incapaz de rejeitar renegociação. Nesta fase, se o operador 
abandona a concessão, surgem custos de transação adicionais e custos políticos devido às críticas da sociedade. Guasch (2006) estende a discussão dos resultados empíricos em Guasch et al. (2003) e desenvolveram um modelo teórico para explicar a execução do contrato imperfeito.

Marques e Berg (2011) examinaram o problema de riscos contratuais de regulação em infraestrutura (serviços públicos de água). Os autores concluem que esse risco, em geral, é calculado de forma errada pelo governo, diminuindo a execução do contrato, levando a rescisão antecipada ou renegociações. Cruz e Marques (2013) usaram um banco de dados com 87 concessões portuguesas. O modelo econométrico realizado por este estudo possui algumas variáveis identificadas que ajudam a explicar a alta probabilidade de renegociação: (i) a duração da concessão e do investimento, ou a existência de um regulador excessivamente interventor. (ii) controle deficiente e má gestão das concessões pelo governo.

Thomas et al. (2012) realizaram um estudo através de questionários e entrevistas em Hong Kong. Os resultados da pesquisa indicam quais os fatores mais críticos na avaliação de projetos PPP: (i) para a comunidade é um nível de tarifa aceitável; (ii) para o setor público é a efetividade na redução de custos e; (iii) a atratividade financeira é o fator de avaliação mais importante do consórcio privado. Além disso, a existência de uma demanda por serviços de longo prazo, a disponibilidade de um consórcio privado forte, o alinhamento com os objetivos estratégicos do governo e a prestação de serviços confiáveis, também são considerados altamente importantes para o sucesso dos esquemas PPP. Xiong et al (2017) desenvolvem um modelo de gerenciamento de risco ex-post. O estudo define critérios para as medidas de resposta ao risco ex-post de acordo com a sua eficácia e características, tendo como base o fluxo financeiro dos projetos de infraestrutura da PPP. 


\section{3}

\section{Fundamentação Teórica}

Parte-se da premissa que comportamento oportunista na PPP ocorre em uma situação pós-assinatura do contrato, caracterizando uma condição de moral hazard. Neste ponto, segue-se Mas-Colell, et al. (1995), demonstrando como o modelo Agente-Principal pode ser adaptado à contratos de PPP. Analisam-se as ações do investidor quando não observáveis para o governo e como pode surgir o comportamento oportunista por parte do investidor. Além disso, apresentam-se mecanismos que o governo detém para ser ótimo o investidor a dizer a verdade sobre seu tipo produtivo e nível de esforço.

\section{1 Modelo Agente - Principal}

Muitos projetos de PPP têm a atribuição de monopólio natural ${ }^{3}$. Neste caso, o governo (principal) é o proprietário do bem/serviço público, que é oferecido via processo de licitação. Como único ofertante do contrato neste mercado, isso the confere a característica monopolista. $\mathrm{O}$ investidor (agente), ao vencer o processo de licitação, é submetido a realizar prestação de serviços públicos que demandam determinado volume de investimentos, caracterizado como nível de esforço a ser empreendido. No desenho da PPP, se tem de fazer um compartilhamento de riscos adequado entre governo e investidor privado para que nem o governo assuma riscos desnecessários e nem jogue para o investidor todos os riscos, pois isso pode afastálos ou ele pode cobrar muito caro por isso. O interesse do governo é maximizar o bem-estar à sociedade e o interesse do investidor é maximizar lucros. Neste sentido, a característica do contrato Agente-Principal auxilia na geração de incentivos corretos, com intuito de evitar o comportamento de redução de esforço do

\footnotetext{
${ }^{3}$ A definição de monopólio natural é uma condição de mercado caracterizada por: (i) custos marginais muito baixos; (ii) investimentos necessários são muitos elevados e; (iii) por serem bens exclusivos e com muito pouca ou ausência de rivalidade. Esses mercados são geralmente regulados pelos governos e possuem prazos de maturação longos. Ver Varian (2010), cap.15.
} 
investidor após da assinatura do contrato. A partir deste ponto, se faz as associações pertinentes em que o governo é o principal e o investidor é o agente.

Primeiramente, supõe-se que o nível de esforço gerado pelo investidor é medido por uma variável unidimensional $e \in[0, \infty)$. O nível de esforço do investidor numa PPP é dado pela qualidade/quantidade de serviços prestados e investimentos em manutenção, expansão, obras etc. $\mathrm{O}$ governo é um maximizador de bem-estar que tem uma função determinística contínua duplamente diferenciável baseada no esforço do investidor na PPP, $w(e)$, com $w(0)=0 ; w^{\prime}(e)>$ $0 ; w^{\prime \prime}(e)<0 \forall e^{4}$. Como dito, o investidor é um maximizador de lucros e sua função de lucros esperada $\Pi(R, e, \theta)$ depende da quantidade de receitas do projeto, do esforço empregado e do estado da natureza, $\theta$, relativo à sua produtividade, como, por exemplo, volume de capital próprio para investimentos, capacidade de obter recursos de terceiros, experiência de gerenciamento no setor e know-how tecnológico, sendo realizado após o contrato ser assinado. Assume-se que $\theta \in \mathbb{R}$, e atribui-se um formato de $\Pi(R, e, \theta)$ que é amplamente usado na literatura:

$$
\Pi(R, e, \theta)=f(R-c(e, \theta))
$$

A função $c(e, \theta)$ mede o custo do esforço para o investidor em unidades monetárias e $R$ são as receitas brutas oriundas do projeto. Assume-se que $c(0, \theta)=$ $0 \forall \theta$ e os subscritos denominam as derivadas parciais:

$$
\begin{aligned}
& c_{e}(e, \theta)\left\{\begin{array}{l}
>0 ; \quad \text { para } e>0 \\
=0 ; \text { para } e=0
\end{array} ; c_{e e}(e, \theta)>0 ; \forall e\right. \\
& c_{\theta}(e, \theta)<0 ; \forall e ; \quad c_{e \theta}(e, \theta)\left\{\begin{array}{l}
<0 ; \quad \text { para } e>0 \\
=0 ; \text { para } e=0
\end{array}\right.
\end{aligned}
$$

As condições em (1.a) tornam o investidor avesso a aumentos em seu esforço e essa aversão é maior quanto maior for o nível de esforço, isto é, em PPPs essa característica colabora com um problema bastante comum em projetos deste tipo, o hold-up ${ }^{5}$. Adicionalmente, altos valores de $\theta$ indicam condições mais produtivas, no sentido de que tanto a queda no lucro total pelo aumento de esforço,

\footnotetext{
${ }^{4}$ Esta condição referencia que o bem-estar social está diretamente relacionado à capacidade e empenho do investidor privado em melhorar a prestação de serviços públicos.

${ }^{5} \mathrm{O}$ problema de hold up aparece em situações de contratos incompletos e investimentos específicos onde um dos agentes de um contrato pode não estar disposto a investir no ativo específico por temer uma perda futura. No contexto aplicado a PPP ver Gregg (2006)
} 
$c(e, \theta)$, quanto a queda marginal do lucro relativo ao custo deste esforço, $c_{e}(e, \theta)$, a qualquer nível de esforço corrente são mais baixos quando $\theta$ é maior.

Em aplicações no mercado de trabalho na literatura de jogos, utiliza-se o nível de utilidade esperada $\bar{u}$, onde o gestor contratado recebe ao aceitar um contrato de acordo $\operatorname{com} \theta$, também chamada de utilidade de reserva. Este nível de utilidade é o mínimo que o principal deve garantir para que um agente avesso ao risco aceite o contrato. Analogamente, alguns editais de PPPs apresentam Garantias de Receitas Mínimas (GRM) para fornecer uma segurança financeira ao projeto e diminuir a exposição do investidor ao risco. A GRM é utilizada quando a expectativa de receita real para um determinado ano $i$ não se confirma na prática. $\mathrm{Na}$ ocorrência de um cenário positivo, em que a receita real fique acima do projetado, há uma partilha de compensação de receitas entre governo e investidor. No caso de cenário negativo, o governo aporta subsídios ao investidor. Brandão e Saraiva (2008) e Brandão et al.(2012) usam a Teoria de Opções Reais demonstrando que as GRM conseguem mitigar risco para o investidor a um baixo custo para o governo. Usando os conceitos de opções financeiras, as calls são empregadas nos cenários positivos e as puts são empregadas em cenários negativos. Como utilizado na literatura de opções, podem-se trazer essas semelhanças comparativas. O principal deve estabelecer ao agente avesso ao risco a obtenção de uma utilidade de reserva, como no exemplo do mercado de trabalho do jogo de screening. Neste trabalho, nomeia-se $\bar{\pi}$ como o lucro mínimo garantido por uma GRM para um investidor avesso ao risco participar do jogo.

Projetos de PPP se caracterizam, especialmente, como um contrato de riscos compartilhados, que tem dois aspectos importantes: primeiro, supõe-se o governo como um proprietário avesso ao risco, mas provendo garantias ao investidor contra flutuações em sua receita. Segundo, o investidor ao tomar conhecimento de tais garantias contratuais, aloca um determinado nível de esforço, pois, contratos de PPP revelam explicitamente o volume de investimentos requerido e serviços públicos a serem prestados. Assim, um contrato que tem um bom balanço de compartilhamento de riscos, deve tornar um aumento na quantidade de esforço sensível a possível queda de lucros incorrida pelo investidor. Por isso, inicialmente, ilustra-se como estes objetivos são executados quando $\theta$ é observável; e na sequência, a análise quando o $\theta$ é observável somente para o investidor. 


\subsection{1 \\ O estado do investidor $\theta$ é observável}

Se $\theta$ é observável, o edital de licitação pode especificar o grau de esforço e as expectativas de receitas do projeto para o investidor em cada realização de $\theta$. Estas variáveis determinam os payoffs econômicos do governo e do investidor. Assim, um contrato com informação completa, onde o governo tenta selecionar o investidor de acordo com as exigências de um contrato de PPP consiste em dois pares: $\left(R_{H}, e_{H}\right) \in \mathbb{R} x \mathbb{R}_{+}$para o estado $\theta_{H}$ e $\left(R_{L}, e_{L}\right) \in \mathbb{R} x \mathbb{R}_{+}$para o estado $\theta_{L}$. O agente $\theta_{H}$ é de alta produtividade e agente $\theta_{L}$ é de baixa produtividade.

O governo, ao oferecer um contrato de um projeto de PPP deve escolher otimamente estes pares para solucionar o seguinte problema:

$$
\begin{aligned}
& \operatorname{Maximizar}_{R_{L}, e_{L} \geq 0} \lambda\left[w\left(e_{H}\right)-R_{H}\right]+(1-\lambda)\left[w\left(e_{L}\right)-R_{L}\right] \\
& R_{H}, e_{H} \geq 0 \\
& \text { Sujeito a } \lambda f\left[R_{H}-c\left(e_{H}, \theta_{H}\right)\right]+(1-\lambda) f\left[R_{L}-c\left(e_{L}, \theta_{L}\right)\right] \geq \bar{\pi}
\end{aligned}
$$

Onde (2.a) é a restrição de participação. Ao descrever $\mathcal{L}$ como a função Lagrangeana, $\lambda \epsilon[0,1]$ o peso relativo do agente $\theta_{i} \operatorname{ser} \theta_{H}$ ou $\theta_{L}$ na função objetivo $\gamma \geq 0$ o multiplicador de Lagrange e $\bar{\pi}$ a lucratividade mínima da PPP. A solução deve satisfazer a seguinte condição de primeira ordem (CPO), tendo $\left[\left(R_{H}^{*}, e_{H}^{*}\right)\left(R_{L}^{*}, e_{L}^{*}\right)\right]$ para o problema (2):

$$
\begin{aligned}
& \partial \mathcal{L} / \partial R_{H}:-\lambda+\gamma \lambda f^{\prime}\left(R_{H}^{*}-c\left(e_{H}^{*}, \theta_{H}\right)\right)=0 \\
& \partial \mathcal{L} / \partial R_{L}: \quad-(1-\lambda)+\gamma(1-\lambda) f^{\prime}\left(R_{L}^{*}-c\left(e_{L}^{*}, \theta_{L}\right)\right)=0 \\
& \partial \mathcal{L} / \partial e_{H}: \lambda W^{\prime}\left(e_{H}^{*}\right)-\gamma \lambda f^{\prime}\left(R_{H}^{*}-c\left(e_{H}^{*}, \theta_{H}\right)\right) c_{e}\left(e_{H}^{*}, \theta_{H}\right)\left\{\begin{array}{c}
\leq 0 \\
=0 \text { se } e_{H}^{*}>0
\end{array}\right. \\
& \partial \mathcal{L} / \partial e_{L}:(1-\lambda) W^{\prime}\left(e_{L}^{*}\right)-\gamma(1-\lambda) f^{\prime}\left(R_{L}^{*}-c\left(e_{L}^{*}, \theta_{L}\right)\right) c\left(e_{L}^{*}, \theta_{L}\right)\left\{\begin{array}{c}
\leq 0 \\
0 \text { se } e_{L}^{*}>0
\end{array}\right.
\end{aligned}
$$


A CPO indica os objetivos de assegurar o investidor avesso ao risco e tornar o esforço sensível a cada tipo de estado da natureza factível. Podemos recombinar as condições (3) e (4) e perceber que:

$$
f^{\prime}\left(R_{H}^{*}-c\left(e_{H}^{*}, \theta_{H}\right)\right)=f^{\prime}\left(R_{L}^{*}-c\left(e_{L}^{*}, \theta_{L}\right)\right)
$$

Assim, tem-se uma relação marginal do lucro em relação às receitas do projeto para o investidor sendo igualada entre os estados. Essa é uma condição em que o governo, por ser avesso ao risco, assegura otimamente o investidor avesso ao risco. A condição (7) implica que $R_{H}^{*}-c\left(e_{H}^{*}, \theta_{H}\right)=R_{L}^{*}-c\left(e_{L}^{*}, \theta_{L}\right)$ que, por sua vez, implica em $f\left(R_{H}^{*}-c\left(e_{H}^{*}, \theta_{H}\right)\right)=f\left(R_{L}^{*}-c\left(e_{L}^{*}, \theta_{L}\right)\right)$, isto é, os lucros para o investidor é igualado entre os estados. Dada a restrição de garantias de receitas mínimas em (2), o investidor, deste modo, tem um nível de lucros de no mínimo $\bar{\pi}$ em cada estado. Dado que $c_{e}\left(0, \theta_{L}\right)=0$, as condições (5) e (6) devem se manter iguais e $e_{i}^{*}>0$ para $i=L, H$. Podemos combinar as condições (3) com (5) e (4) com a (6), notando que o grau ótimo de esforço no estado $\theta_{i}, e_{i}^{*}$, satisfaz:

$$
w^{\prime}\left(e_{i}^{*}\right)=c_{e}\left(e_{i}^{*}, \theta_{i}\right) \quad \text { para } i=L, H
$$

A condição (8) diz que o nível ótimo de esforço no estado $\theta_{i}$ deve igualar o benefício marginal de bem-estar com o custo marginal do investidor relativo a seu nível de esforço. A figura 1 mostra o vetor ótimo do investidor $\left(e_{i}^{*}, R_{i}^{*}\right)$. Um arranjo mais acima e a esquerda coloca o investidor em uma posição melhor (maior receita e nível menor de esforço), e o governo está melhor quando se move na direção contrária.

Como o governo garante ao investidor receber nível de receitas mínimas que garanta $\bar{\pi}$, o mesmo busca encontrar o ponto em que possa extrair o máximo de esforço possível para assegurar um nível de bem-estar social associado ao estado $\theta_{i}{ }^{6}$. A condição de equilíbrio é dada pela tangência da curva de receitas do investidor e a curva de bem-estar do governo ${ }^{7}$. O nível de bem-estar do governo

\footnotetext{
${ }^{6}$ No caso do modelo de screening para o mercado de trabalho, o equilíbrio é um ponto de tangência entre a curva de indiferença do gestor e a curva de isolucro do proprietário. Aqui as condições são especialmente diferentes, pois o investidor é um maximizador de lucros.

${ }^{7}$ Assim, o benefício marginal para o esforço adicional em termos de aumento de bem-estar é exatamente igual ao custo marginal $c_{e}\left(e_{i}^{*}, \theta_{i}\right)$ suportado pelo investidor.
} 
associado a $\theta_{i}$ é $\mathrm{w}_{i}^{*}=w\left(e_{i}^{*}\right)-f^{-1}(\bar{\pi})-c\left(e_{i}^{*}, \theta_{i}\right){ }^{8}$ Para a condição (8), tem-se $c_{e \theta}(e, \theta)<0 ; w^{\prime \prime}(e)<0 ; c_{e e}(e, \theta)>0$, implicando em $e_{H}^{*}>e_{L}^{*}$. A figura 2 a seguir descreve o contrato ótimo $\left.\left[e_{H}^{*}, R_{H}^{*}\right),\left(e_{L}^{*}, R_{L}^{*}\right)\right]$

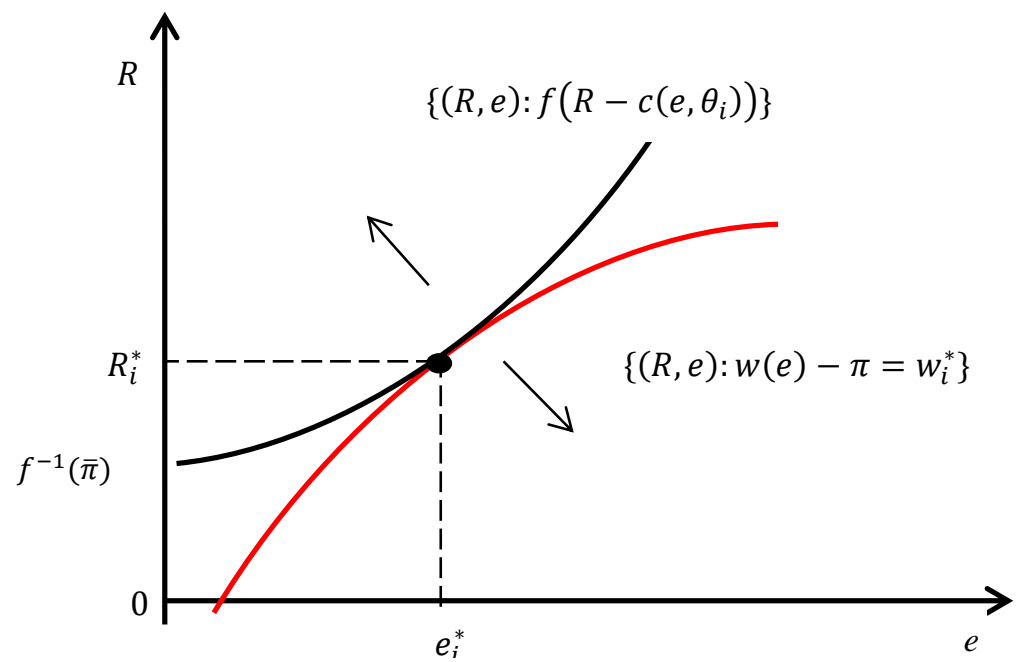

Figura 1. Par ótimo $\left(R_{i}^{*}, e_{i}^{*}\right)$ para o estado $\theta_{i}$ quando observável (adaptado de Mas-Colell et al, 1995).

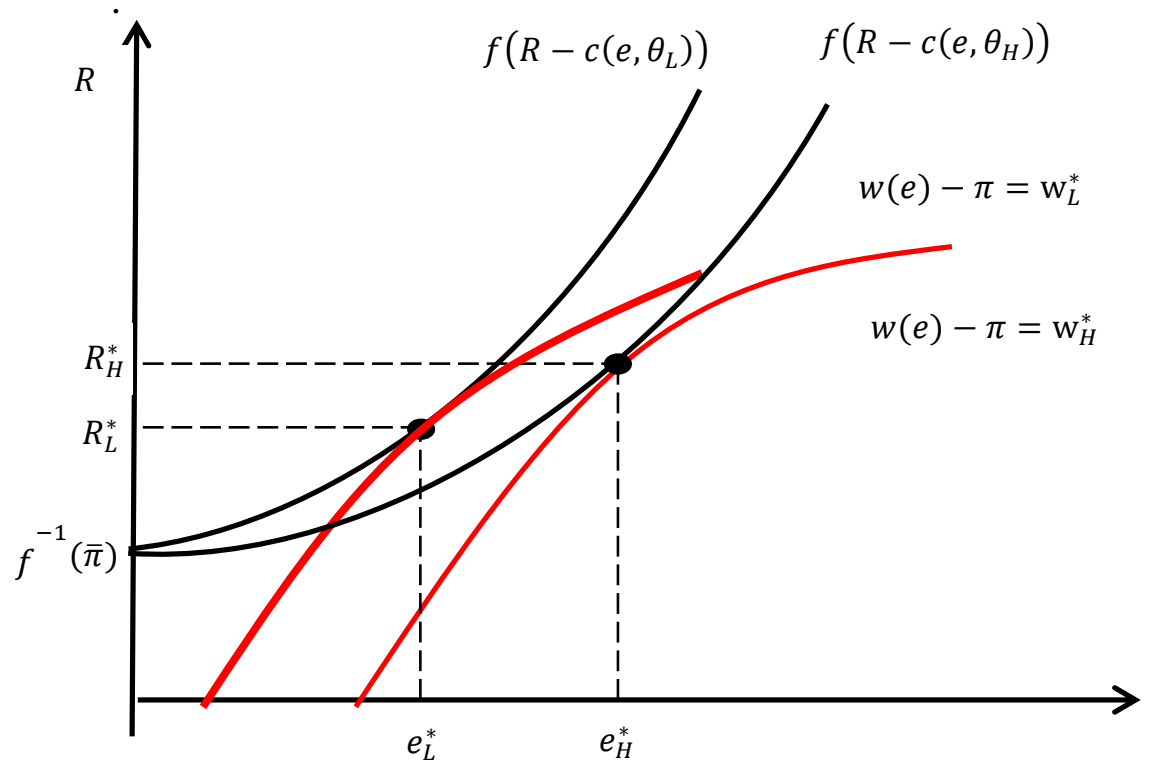

Figura 2 - Contrato ótimo para $\theta_{L}$ e $\theta_{H}$ na PPP com estado observável. (adaptado de MasColell et al, 1995)

Em um jogo de screening monopolista para o mercado de trabalho, a condição exposta na figura 2 demonstra um modelo contratual em que o principal,

\footnotetext{
8 Dado que $w(0)=0$, se as receitas até este ponto no eixo vertical é $\hat{R}<0$, o nível de bem-estar do governo em $\left(R_{i}^{*}, e_{i}^{*}\right)$ é exatamente $-\hat{R}$.
} 
em uma situação de informação completa, consegue definir otimamente os contratos para cada um dos tipos de agentes $\theta_{H}$ e $\theta_{L}$. Para a análise aplicada as PPP's, a figura 2 ajuda a entender como pode surgir o comportamento oportunista do agente ganhador do processo de licitação após a assinatura do contrato. O resultado esperado pelo governo como licitante é selecionar o melhor investidor possível neste processo de triagem, que no caso é o agente que pode gerar maior bem-estar social com o menor custo possível, ou seja, $\theta_{H}$. Ao se impor que o agente de maior produtividade é o selecionado, este pode diminuir seu esforço $e_{H}^{*}$ para o nível $e_{L}^{*}$ e o nível de receitas diminui de $R_{H}^{*}$ para $R_{L}^{*}$, no entanto, não em uma escala tão significante que não valha a pena ele diminuir a quantidade de seu esforço. Quando o governo não consegue observar diretamente no nível de esforço gerado pelo investidor, surge o problema de informação assimétrica onde somente o investidor privado sabe o quanto de esforço empreende no projeto. A proposição 1 sumariza as condições iniciais e assegura a participação do investidor no contrato.

Proposição 1 - No modelo agente-principal aplicado à PPPs sendo o estado $\theta$ observável, o contrato ótimo envolve um nível de esforço $e_{i}^{*}$ no estado $\theta_{i}$ tal que $w^{\prime}\left(e_{i}^{*}\right)=c\left(e_{i}^{*}, \theta_{i}\right)$ e que forneça garantias ao investidor avesso ao risco, definindo suas receitas mínimas para participar do contrato em cada estado ao nível $R_{i}^{*}$ tal que $f\left(R_{i}^{*}-c\left(e_{i}^{*}, \theta_{i}\right)\right)=\bar{\pi}^{9}$.

\subsection{2 \\ O estado $\theta$ é observado somente pelo investidor}

As condições colocadas anteriormente encontram dificuldades quando a informação não é de conhecimento comum entre todos os jogadores. A suposição inicial é que o governo ofereça no edital de licitação um contrato de PPP ao investidor que o vincule a revelar a verdade sobre seu tipo $\theta_{i}$. Baseado na figura 2 viu-se que o nível $\theta_{H}$ exige um esforço proporcionalmente maior que $\theta_{L}$. Isso pode fazer com que o investidor tenha um comportamento oportunista, uma vez que o ponto $\left(e_{L}^{*}, R_{L}^{*}\right)$ se torna preferível ao ponto $\left(e_{H}^{*}, R_{H}^{*}\right)$ para $\theta_{H}$. Logo, o investidor $\theta_{H}$, em uma situação de assimetrias, pode praticar nível de esforço $e_{L}^{*}$, e por

\footnotetext{
${ }^{9}$ A proposição contratual do mercado de trabalho adaptada para PPPs pode ser encontrada em Mas-Colell et al (1995), pg.492.
} 
consequência, o nível de bem-estar que o governo pretende adquirir também será menor. Além disso, como a qualidade dos serviços prestados se torna inferior aos objetivos do governo, o menor nível de esforço dado pelo comportamento oportunista da parte privada pode incentivá-lo a aportar subsídios equivocados que, sem o problema da assimetria de informação, se fazem desnecessários e evitariam custos econômicos e políticos de renegociação, Ho (2006).

Um contrato que implementa o princípio da revelação, faz ser ótimo ao agente realizar um anuncio sobre seu verdadeiro tipo $\theta$. Posteriormente, o agente é livre para escolher seu nível de esforço sabendo que terá uma função de contrapartida $\pi(W \mid \hat{\theta})$ que depende de seu anuncio $\hat{\theta}$. A definição do principio da revelação foi realizada nos trabalhos pioneiros de Myerson (1979) e Dagsputa, Hammond e Maskin (1979).

Podem-se adaptar os conceitos do princípio da revelação para contratos de PPP de forma a evitar o comportamento oportunista. Primeiro, nomeia-se $\Theta$ como o conjunto de possíveis estados da natureza. O governo é um maximizador de bemestar que pode oferecer um contrato ótimo que detém as seguintes condições: (i) após o estado $\theta$ ser realizado (resultado da licitação), o investidor é exigido a cumprir o esforço compatível com o estado revelado; (ii) o contrato especifica um resultado $[R(\hat{\theta}), e(\hat{\theta})]$ para cada possível anuncio $\hat{\theta} \in \Theta$; (iii) em cada estado $\theta \in \Theta$.

Ao usar o mecanismo com incentivos em um contrato de PPP, a parte privada compulsoriamente deve anunciar qual o seu tipo $\theta$ e isso vincula os resultados de bem-estar aos possíveis anúncios. Supõe-se que o governo oferece um contrato de PPP que programa ganhos associados ao grau de bem-estar gerado à sociedade $^{10}, \pi(w)$, permitindo ao investidor escolher seu nível esforço. Como exposto, temos apenas dois resultados possíveis de esforço, $e_{L}$ e $e_{H}$, que são associados respectivamente a $\theta_{L}$ e $\theta_{H}$. Ao se assumir que o governo propõe, já no edital, o mecanismo de revelação, se o investidor anunciar que seu tipo é $\theta_{L}$, o resultado esperado para este estado é $\left[\pi\left(w\left(e_{L}\right)\right), e_{L}\right]$ e se o investidor anuncia que é

\footnotetext{
${ }^{10}$ Em jogos do tipo agente-principal do mercado de trabalho, a premissa básica para o equilíbrio é que os salários são pagos de acordo com o nível de produtividade e maior é o salário do agente quanto maior forem os resultados gerados para o proprietário. Aqui a relação é análoga, melhor será o resultado para o investidor se este atua provendo um serviço público de alta qualidade.
} 
$\theta_{H}$ espera-se o resultado $\left[\pi\left(w\left(e_{H}\right)\right), e_{H}\right]$. Porém, um contrato de PPP sem mecanismos de incentivos, com recompensa $\pi(w)$, o investidor $\theta_{H}$ poderia alcançar o resultado $\left[\pi\left(w\left(e_{L}\right)\right), e_{L}\right]$ ao fazer esforço $e_{L}$, ao invés de escolher o nível $e_{H}$. Assim, sob o mecanismo proposto que atende ao princípio da revelação, o investidor procurará dizer a verdade para obter um retorno ótimo quando o estado é $\theta_{H}$. Segundo Mas-Colell et al. (1995) os resultados do princípio da revelação fazem o agente anunciar a verdade e produz exatamente o mesmo resultado do contrato original (em que $\theta$ é diretamente observável) e argumentos similares são construídos para quaisquer contratos ${ }^{11}$.

O sucesso de uma PPP também está associado a um compartilhamento de riscos eficiente, isso requer que um investidor avesso ao risco ${ }^{12}$ tenha nível de lucros mínimos $\bar{\pi}$ em cada estado para aceitar o contrato. Caso o resultado seja $\bar{\pi}$ em um estado e $\pi^{\prime}$ em outro, sendo $\pi^{\prime}<\bar{\pi}$, então, o governo deve fornecer um aporte financeiro que garanta ao investidor um lucro esperado $\bar{\pi}$ mantendo a viabilidade financeira do projeto. $\mathrm{O}$ estado $\theta$ pode tomar somente dois valores: $\theta_{H} \mathrm{e}$ $\theta_{L}, \operatorname{com} \theta_{H}>\theta_{L}$ e $\operatorname{prob}\left(\theta_{H}\right)=\lambda \epsilon[0,1]$. O nível de produtividade é definido pela capacidade técnica/financeira do agente em operar e gerenciar uma PPP, portanto, $\theta_{H}>\theta_{L}$. Ao se assumir tal premissa sob a posição ao risco do investidor, o princípio da revelação descreve o seguinte problema de maximização de bem-estar do governo:

$$
\operatorname{Maximizar}_{R_{L}, e_{L} \geq 0} \lambda\left[W\left(e_{H}\right)-R_{H}\right]+(1-\lambda)\left[W\left(e_{L}\right)-R_{L}\right]
$$

Sujeito a:

$$
\begin{aligned}
& R_{L}-c\left(e_{L}, \theta_{L}\right) \geq f^{-1}(\bar{\pi}) \\
& R_{H}-c\left(e_{H}, \theta_{H}\right) \geq f^{-1}(\bar{\pi}) \\
& R_{H}-c\left(e_{H}, \theta_{H}\right) \geq R_{L}-c\left(e_{L}, \theta_{H}\right)
\end{aligned}
$$

\footnotetext{
${ }^{11}$ Ver cap.23 Mas - Colell et al. (1995)

12 Assume-se o que o investidor é fortemente avesso ao risco, ou seja, não há qualquer probabilidade que o agente tome outro posicionamento, durante o tempo de contrato, diante do risco. Ver pg.494 de Mas - Colell et al (1995).
} 


$$
R_{L}-c\left(e_{L}, \theta_{L}\right) \geq R_{H}-c\left(e_{H}, \theta_{L}\right)
$$

As restrições (9.a) e (9.b) compõem a restrição individual de receitas mínimas garantidas para um investidor avesso o risco. Após o processo de licitação, o contrato deve assegurar um nível de lucratividade de pelo menos $\bar{\pi}$ em cada estado. Portanto, devemos ter $f\left(R_{i}-c\left(e_{i}, \theta_{i}\right)\right) \geq \bar{\pi}$ para $i=L, H$.

A restrição compatível com incentivos é fornecida pelas restrições (9.c) e (9.d) para o investidor avesso ao risco de acordo com os tipos, $\theta_{H}$ e $\theta_{L}$, respectivamente. Ao propor que $\theta_{H}$ é o investidor vencedor da licitação, podemos verificar que o lucro deste investidor é $f\left(R_{H}-c\left(e_{H}, \theta_{H}\right)\right)$ se ele diz a verdade sobre seu tipo, entretanto, se este atua de maneira oportunista se comportando como um $\theta_{L}$ o resultado será $f\left(R_{L}-c\left(e_{L}, \theta_{H}\right)\right)$. Assim, o governo ao montar um edital de licitação que vincule o investidor a dizer a verdade condiciona ${ }^{13}$ :

$$
f\left(R_{H}-c\left(e_{H}, \theta_{H}\right)\right) \geq f\left(R_{L}-c\left(e_{L}, \theta_{H}\right)\right)
$$

As condições de primeira ordem para o problema de maximização exposto em (9) são demonstradas no apêndice deste trabalho. Expõe-se a seguir uma sequência de proposições provenientes de Mas-Colell et al.(1995) utilizando análise gráfica para construir a intuição e que são aqui adaptados e modificados para contratos de PPP, analisando os impactos do oportunismo.

Proposição 2: Considere o relaxamento da restrição (9.b) para o investidor $\theta_{H}$. Um contrato de PPP que evita o comportamento oportunista será uma solução ao problema (9) se e somente se for uma solução para o problema derivado de (9) ao se desconsiderar a restrição (9. $b)$.

Prova: Sempre que as restrições (9.a) e (9.c) forem atendidas, tal que $R_{H}-c\left(e_{H}, \theta_{H}\right) \geq R_{L}-c\left(e_{L}, \theta_{H}\right) \geq R_{L}-c\left(e_{L}, \theta_{L}\right) \geq f^{-1} \bar{\pi} \quad$ a restrição também é satisfeita. Isso implica que o contrato de PPP factível no problema

\footnotetext{
${ }^{13}$ Pode-se realizar o mesmo exercício para o agente $\theta_{L}$, Se assumíssemos o comportamento oportunista do agente $\theta_{L}$, ou seja, aquele que ganha a licitação mesmo numa condição incentivo compatível, teríamos que considerar um cenário de renegociação através de subsídios do governo. Na prática quando o agente de baixa capacidade ganha o processo de licitação, atua de maneira oportunista solicitando subsídios maiores do que o contratado em um momento futuro justamente por não ter condições produtivas e gerenciais, e o governo devido ao custo político renegocia o projeto. Veja em Ho \& Tsui (2010) o caso do projeto do trem de alta velocidade em Taiwan para maiores detalhes.
} 
derivado de (9) ao abandonar a restrição (9.b) é exatamente o mesmo no problema (9).

A figura 2 mostrava um contrato ótimo, onde as ações do agente eram completamente observáveis, que resultava estritamente em $R_{H}-c\left(e_{H}, \theta_{H}\right)>R_{L}-$ $c\left(e_{L}, \theta_{L}\right)$, violando a restrição (9.c). A figura 3 reforça a prova sobre a proposição 2. Ao notar a restrição (9.a), $\left(e_{L}, R_{L}\right)$ deve situar-se na região sombreada da figura 3 (acima de $f^{-1}(\bar{\pi})$ ). Entretanto, pela restrição (9.c), $\left(e_{H}, R_{H}\right)$ deve situar-se sobre ou acima da curva de receitas do tipo $\theta_{H}$ que também passa pelo ponto $\left(e_{L}, R_{L}\right)$. Quando o comportamento oportunista de $\theta_{H}$ ocorre, há o cruzamento das curvas de receitas. De fato, a curva $f\left(R-c\left(e_{L}, \theta_{H}\right)\right)=\pi_{H}>\bar{\pi}$ mostra que o investidor oportunista torna-se indiferente entre os pares $\left(e_{H}, R_{H}\right)$ e $\left(e_{L}, R_{L}\right)$. A obtenção de payoff oportunista é fornecida pela curva tracejada, $f\left(R_{L}-c\left(e_{L}, \theta_{H}\right)\right)$, representando a diminuição de esforço $e_{H}$ para $e_{L}$, quebrando o equilíbrio separador do contrato. Como pode ser visto, isso implica que o lucro do investidor do estado $\theta_{H}$ é pelo menos $\bar{\pi}$, que é o lucro mínimo garantido que ele recebe no ponto $(w, e)=\left(f^{-1}(\bar{\pi}), 0\right)$.

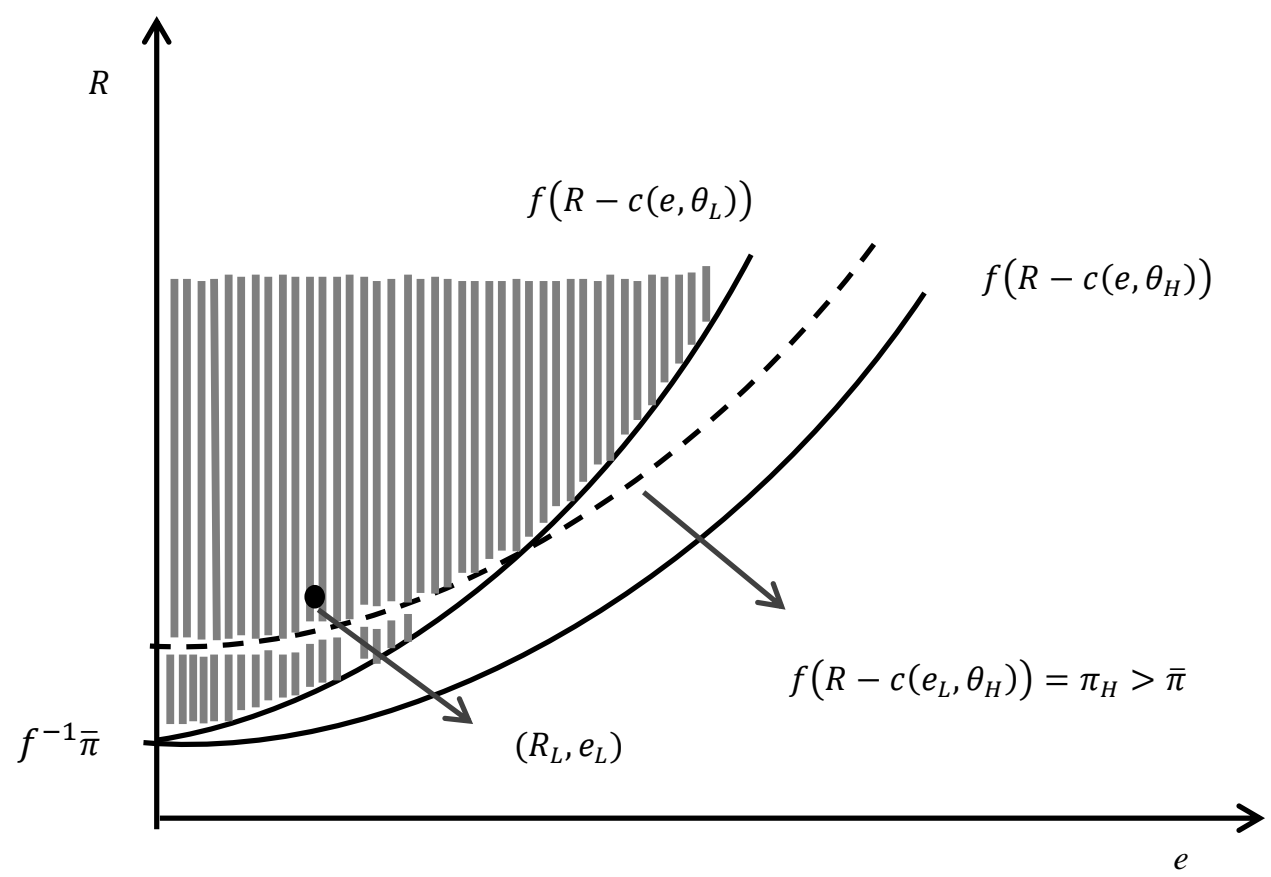

Figura 3 - Indiferença entre o ponto $\left(e_{L}, R_{L}\right)$ e $f\left(R-c\left(e, \theta_{H}\right)=\pi_{H}\right.$. (adaptado de Mas-Colell et al, 1995) 
Proposição 3: O contrato ótimo que desincentiva o comportamento oportunista para o problema (9) deve ter:

$$
\begin{aligned}
& R_{H}-c\left(e_{H}, \theta_{H}\right) \geq R_{L}-c\left(e_{L}, \theta_{H}\right)>f^{-1}(\bar{\pi}) \mathrm{e} \\
& R_{L}-c\left(e_{L}, \theta_{L}\right)=f^{-1}(\bar{\pi})^{14}
\end{aligned}
$$

Prova: Suponha que $\left(R_{H}, e_{H}\right)$ não seja a solução ótima na qual $R_{H}-$ $c\left(e_{H}, \theta_{H}\right) \geq R_{L}-c\left(e_{L}, \theta_{H}\right)>f^{-1}(\bar{\pi})$. Considerando uma alteração contratual do governo que mude as garantias de receitas mínimas que gere $\hat{R}_{H}=R_{H}-\varepsilon$, com $\hat{R}_{H} \geq R_{L}$ e $\varepsilon>0$ seja suficientemente pequeno que ainda satisfaça a restrição (9.b). Além do mais, as restrições compatíveis com incentivos seriam satisfeitas, $\left(R_{H}-\right.$ $\varepsilon)-c\left(e_{H}, \theta_{H}\right) \geq R_{L}-c\left(e_{L}, \theta_{H}\right)$. Entretanto, se este contrato de PPP alterado também satisfaz todas as restrições, o contrato original não pode ser ótimo, pois esta modificação contratual incentiva o investidor a se comportar de maneira oportunista e diminui ainda mais seu esforço de $\hat{e}$ para $e_{L}$ posto que a receita $\hat{R}_{H}$ não é estritamente maior do que $R_{L}$.

As figuras 4 e 5 são balizadas na figura 2 e ajudam a ilustrar o problema. Caso $\hat{R}_{H}$ seja suficientemente próximo de $R_{L}$ para fazer o investidor gerar um novo esforço $\hat{e}$ associado, em que $e_{H}>\hat{e}>e_{L}$, o investidor tem incentivos para diminuir ainda mais seu esforço até o nível $e_{L}$. A figura 4 ilustra o primeiro movimento feito por uma alteração pós-contratual, isto é, uma ação oportunista do governo, expropriando receitas do projeto, no qual a receita $R_{H}^{*}$ cai para $\hat{R}_{H}$.

A figura 5 ilustra o movimento de reação por parte do investidor. Nesta situação, o investidor $\theta_{H}$ recebe incentivos para se comportar de modo oportunista. Isso ocorre, pois o agente $\theta_{H}$ sabe que por ter $c_{e}\left(e, \theta_{H}\right)<c_{e}\left(e, \theta_{L}\right)$, reduzir seu esforço $\hat{e}$ para $e_{L}$, que é o volume financeiro a se investir na PPP, a queda de receitas compreendida no espaço entre $\hat{R}_{H}$ e $R_{L}$ não é proporcionalmente tão elevada quanto a diminuição de seu esforço.

\footnotetext{
${ }^{14}$ Para $R_{L}-c\left(e_{L}, \theta_{L}\right)=f^{-1}(\bar{\pi})$ a prova pode ser realizada sobre a mesma ótica, em que $\left(R_{L}, e_{L}\right)$ não seja a solução ótima na qual $R_{L}-c\left(e_{L}, \theta_{L}\right)>f^{-1}(\bar{\pi})$. Como o foco é realizado sobre o agente oportunista ganhador da licitação, a garantia mínima para $\theta_{L}$, participar do jogo, ou seja, aceitar o contrato é ter payoff no mínimo igual a $f^{-1}(\bar{\pi})$.
} 


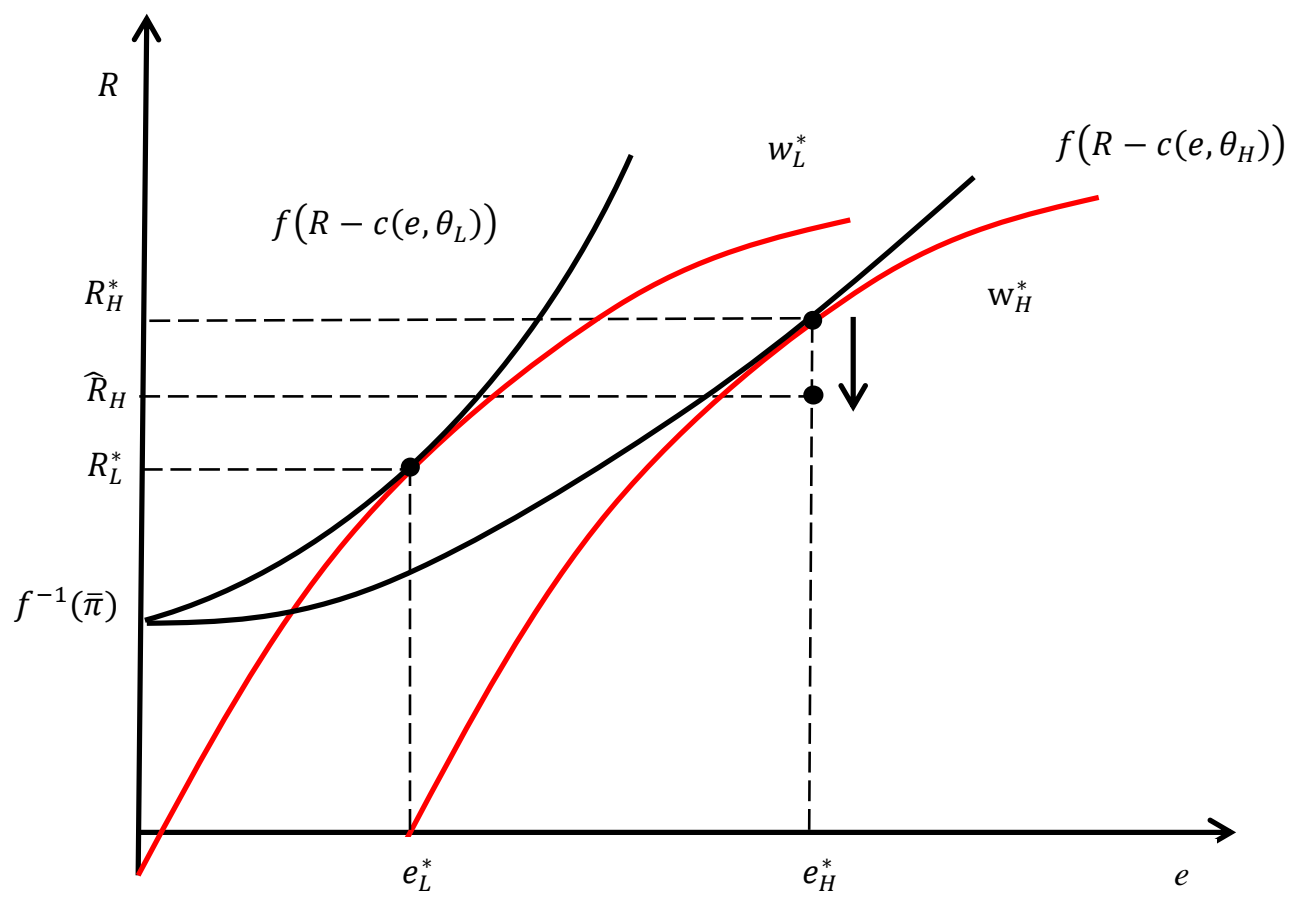

Figura 4 - Movimento oportunista do governo nas receitas do projeto

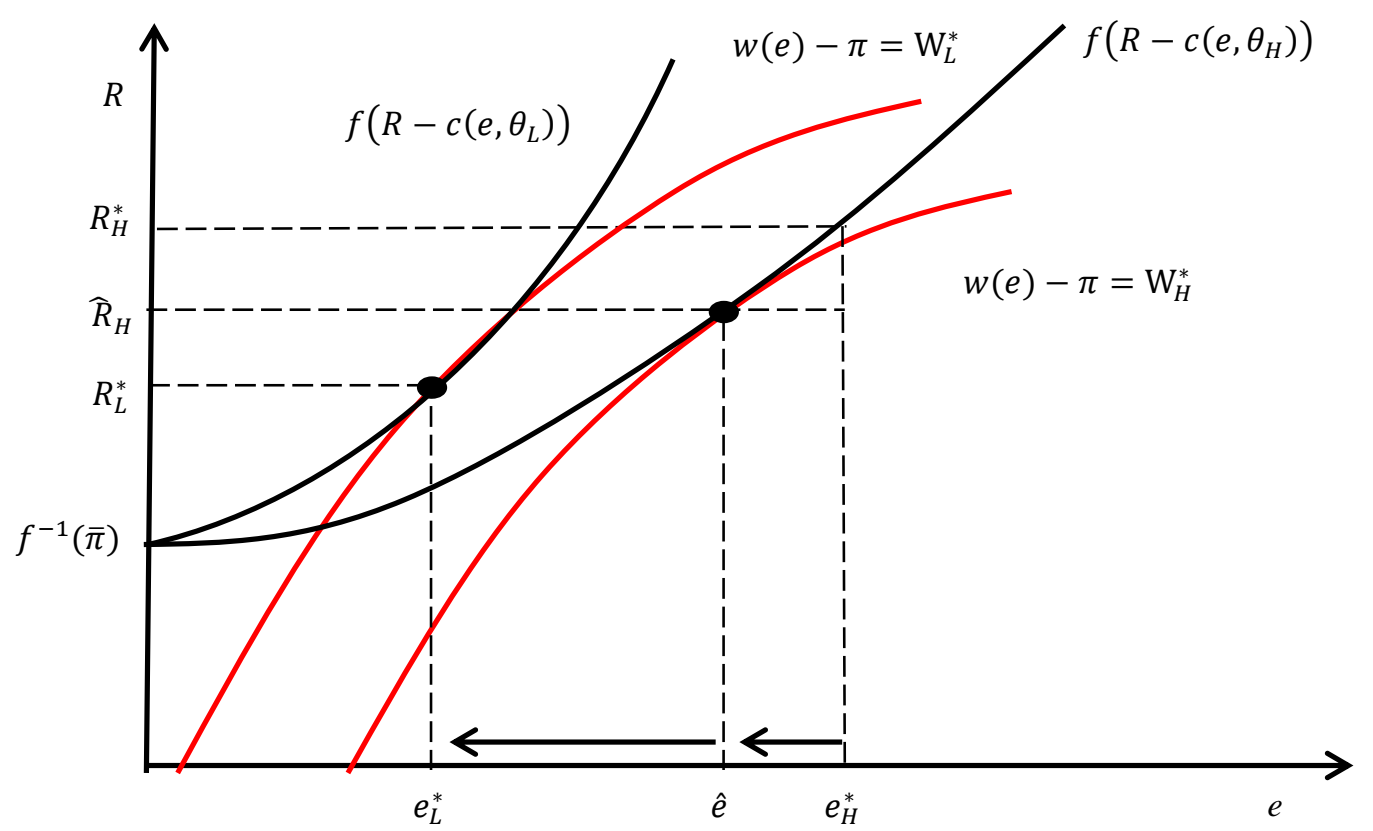

Figura 5 - Movimento oportunista por parte do investidor

Portanto, o ponto $\left(\hat{R}_{H}, \hat{e}\right)$ que percorre a curva $f\left(R-c\left(e, \theta_{H}\right)\right)$ sugere que uma alteração no contrato pode incentivar o investidor a diminuir ainda mais seus investimentos no projeto de PPP até a curva $f\left(R-c\left(e, \theta_{L}\right)\right)$ se comportando de maneira oportunista e o governo iria para um resultado inferior de bem$\operatorname{estar} w(e)-\pi=\mathrm{W}_{L}^{*}$. 
Proposição 4: Um contrato de PPP ótimo que evita o comportamento oportunista condiciona:

(i) $e_{L} \leq e_{L}^{*}$, isto é, o nível de esforço do investidor no estado $\theta_{L}$ não é maior do que poderia ocorrer se $\theta$ fosse diretamente observável.

(ii) $e_{H}=e_{H}^{*}$, logo, o contrato deve extrair do investidor $\theta_{H}$ o nível de esforço igual ao que poderia ocorrer se $\theta$ fosse diretamente observável.

Prova: Para a Proposição 4, utiliza-se a segunda condição do Proposição 3 em que o contrato de PPP ótimo, o par $\left(e_{L}, R_{L}\right)$ posiciona-se em $\{(R, e): f(R-$ $\left.\left.c\left(e, \theta_{L}\right)\right)=(\bar{\pi})\right\}$. A figura 6 retrata um possível par $\left(\widehat{e}_{L}, \hat{R}_{L}\right)$ e as implicações para o estado $\theta_{H}$. Pela restrição (9.d), $\left(e_{H}, R_{H}\right)$ deve se situar sobre ou abaixo da curva $f\left(R-c\left(e, \theta_{L}\right)\right)$ e por (9.c), $\left(e_{H}, R_{H}\right)$ deve se localizar sobre ou acima da curva $f\left(R-c\left(e, \theta_{H}\right)\right)=\pi_{H}>\bar{\pi}$ que passa por $\left(\widehat{e}_{L}, \hat{R}_{L}\right)$. Como a restrição (9.c) implica que o par $\left(R_{H}, e_{H}\right)$ deve ficar em qualquer ponto da região sombreada, o ponto $\left(\widehat{e}_{L}, \hat{R}_{L}\right)$ mostra a contradição gerada pelo comportamento oportunista pois $\left(\widehat{e_{L}}, \hat{R}_{L}\right)$ e $\left(e_{H}, R_{H}\right)$ segundo as restrições compatíveis com incentivos não podem ser indiferentes para o investidor.

Para complementar a análise do item (i) da proposição 4 , faz-se $\hat{e}_{L}>e_{L}^{*}$. A figura 7 adiciona a figura 6 conclusões mais evidentes neste tipo de contrato. Nela descreve-se o par $\left(\widehat{e_{L}}, \hat{R}_{L}\right)$ na curva de lucratividade do investidor $\theta_{L}$ e a restrição (9.c) indica que o par $\left(R_{H}, e_{H}\right)$ aloca-se na região sombreada. Como $\hat{e}_{L}>e_{L}^{*}$, o ponto $\left(\widehat{e_{L}}, \hat{R}_{L}\right)$ indica a curva de lucro oportunista e de bem-estar do governo que atravessa o ponto $\left(\widehat{e}_{L}, \widehat{R}_{L}\right)$. Esta situação não é factível, pois, como pode ser observado, o contrato que vincula à realização de esforço $\hat{e}_{L}>e_{L}^{*}$ não pode ser suportado o investidor $\theta_{L}$ pois $c_{e}\left(e_{L}^{*}, \theta_{L}\right)>c_{e}\left(e_{H}^{*}, \theta_{H}\right)$, fazendo com que $\theta_{L}$ atue de maneira oportunista ${ }^{15}$ e o retorno de bem-estar do projeto para o governo diminui. Logo, $\hat{e}_{L}>e_{L}^{*}$ não pode ser ótimo.

\footnotetext{
${ }^{15}$ No caso, o agente $\theta_{L}$ pediria subsídios além do contratado para o governo para cobrir seus custos por se comportar como um investidor do tipo $\theta_{H}$.
} 


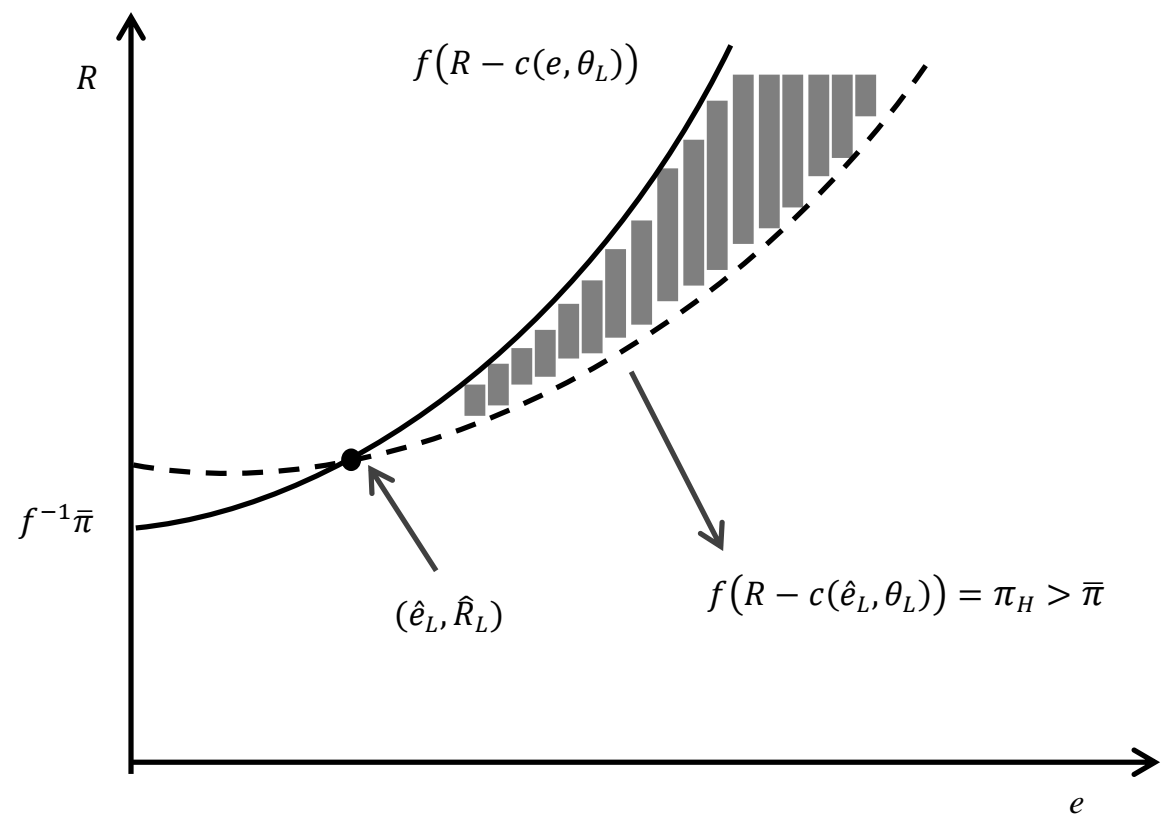

Figura 6 - $\left(e_{H}, R_{H}\right)$ e $\left(e_{L}, R_{L}\right)$ não são indiferentes para o investidor. (adaptado de MasColell et al, 1995)

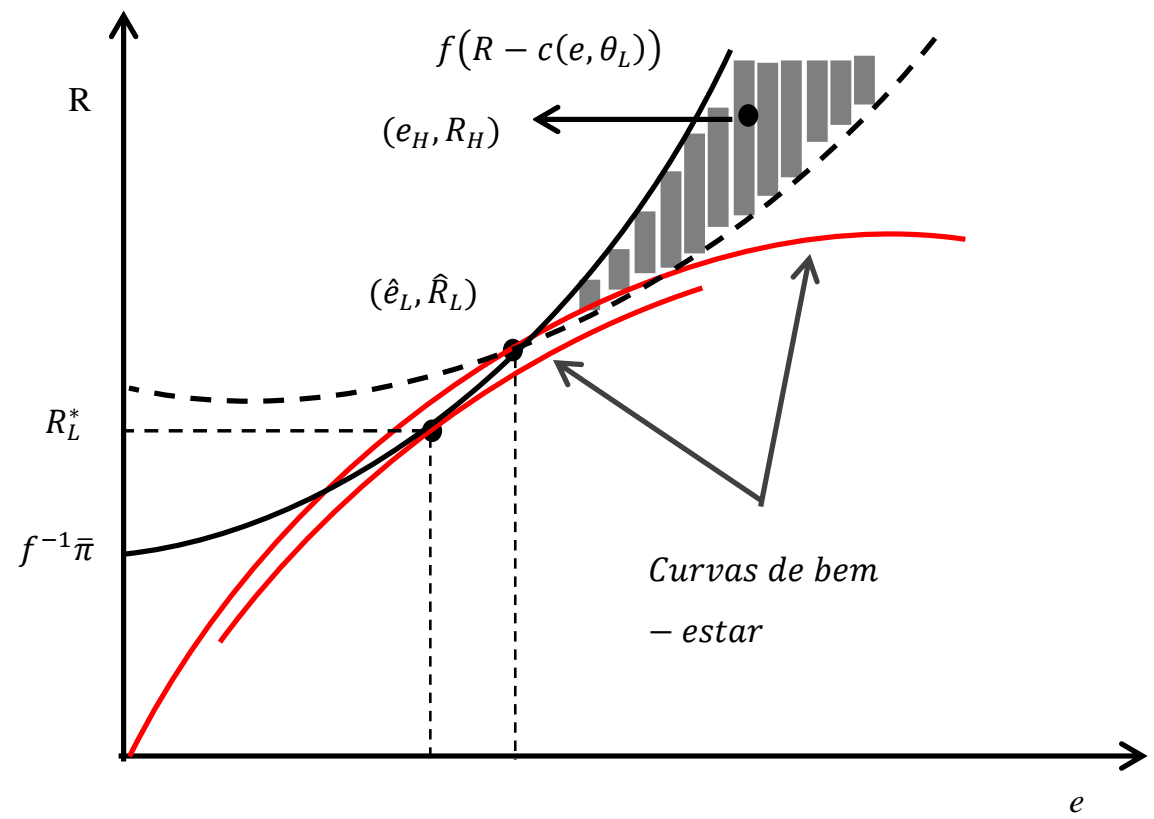

Figura 7- O contrato ótimo tem $e_{L} \leq e_{L}^{*}$ (adaptado de Mas-Colell et al, 1995)

A condição do item (ii) da Proposição 4 exige que o contrato do governo extraia $e_{H}=e_{H}^{*}$ que seria o nível ótimo de esforço caso não houvesse problemas de assimetria. Exibe-se na figura 8 o par $\left(\hat{e}_{L}, \hat{R}_{L}\right)$ tal que $\hat{e}_{L}<e_{L}^{*}$, onde o problema do governo é encontrar o lócus ótimo para $\left(e_{H}, R_{H}\right)$ que maximiza o bem-estar da 
sociedade no estado $\theta_{H}$ e evita que o investidor tenha um comportamento oportunista.

Utiliza-se a solução de contrato dada pela condição (8), que no estado $\theta_{H}$ é $W^{\prime}\left(e_{H}^{*}\right)=c_{e}\left(e_{H}^{*}, \theta_{H}\right)$. Admite-se, além disso, que o ponto de tangência entre a curva de receitas do investidor e a curva de bem-estar $\widetilde{\mathrm{W}}_{H}$ também passa pelo ponto $\left(\hat{e}_{L}, \hat{R}_{L}\right)$. Isso mostraria que o contrato não extrai todo esforço possível do investidor $\theta_{H}$ ou que ele atua de maneira oportunista diminuindo seu esforço. Tal condição quebra a restrição $(9 . c)$, pois tanto o ponto $\left(e_{H}^{*}, \widetilde{R}_{H}\right)$ tangente à curva $\widetilde{\mathrm{W}}_{H}$, que envolve nível de esforço $e_{H}^{*}$, quanto o ponto $\left(\hat{e}_{L}, \hat{R}_{L}\right)$, o tornariam indiferente com relação entre os pares $\left(e_{H}^{*}, \widetilde{R}_{H}\right)$ e $\left(\hat{e}_{L}, \hat{R}_{L}\right)$. Logo, a curva $\widetilde{\mathrm{W}}_{H}$ não gera o máximo de bem-estar à sociedade.



Figura 8- Um contrato ótimo tem $e_{H}^{*}=e_{H}$

Nota-se pela figura 8 que o ponto de tangência ocorre estritamente à direita de $\hat{e}_{L}$, pois $\hat{e}_{L} \leq e_{L}^{*}<e_{H}^{*}$. Portanto, a proposição 3 ajuda a verificar que, para evitar que o investidor se comporte de maneira oportunista pós assinatura, a aplicação da restrição compatível com incentivos reveladora da verdade para o estado $\theta_{H}$ é obrigatória no contrato ótimo de PPP. 


\section{4 \\ Análise de caso: Complexo Maracanã}

\section{1 Contexto}

Em 09 de Abril de 2013, o processo de licitação do Maracanã foi vencido pelo Consórcio Maracanã SA - formado pelas empresas IMX, Odebrecht e AEG do edital de licitação de concorrência Casa Civil do Governo Estado do Rio de Janeiro (GERJ) No 03/2013. O regime é o de PPP, modalidade concessão administrativa, do serviço de gestão, operação e manutenção do estádio Mário Filho e do ginásio Gilberto Cardoso (Maracanãzinho) e acumulada com obras incidentais. Dentre as obras estruturais, a concessionária é obrigada a realizar os gastos com a demolição do Estádio de Atletismo Célio de Barros (EACB), do Parque Aquático Júlio Delamare (PAJD), do Presídio Evaristo de Moraes e da Escola Municipal Friedenreich. Segundo o edital os imóveis acima indicados serão entregues à concessionária livres de quaisquer ônus e encargos, prontos para a sua utilização. Segundo o edital e a empresa $\mathrm{IMX}^{16}$ o valor estimado de investimentos é de R $\$ 594$ milhões mais $\mathrm{R} \$ 181$ milhões de aluguel e receitas esperadas de $\mathrm{R} \$ 1,494$ bilhões em um período de 35 anos.

Os primeiros problemas de oportunismo contratual surgiram quatro meses após o início da concessão. O governo do Estado suspendeu a demolição do EACB e o PAJD. Estas duas edificações dariam lugar a dois edifícios-garagem e um shopping. Com expectativa de receita de no mínimo $\mathrm{R} \$ 20$ milhões anuais, a concessionária já coletava sua primeira perda de receitas. Segundo balanço financeiro da Concessionária Maracanã, em 2013 e 2014 houve prejuízos de R\$48 milhões e R \$77,2 milhões, respectivamente, e estimativa de R 57 milhões em 2015. Em agosto de 2015 houve uma renegociação contratual entre o GERJ e a concessionária que a exime de realizar investimentos no PAJD e no Maracanãzinho, tentando minimizar os impactos financeiros das mudanças contratuais desde sua assinatura diminuindo os investimentos necessários para

${ }^{16}$ Atualmente a empresa se chama IMM 
R\$130 milhões. Além disso, em janeiro de 2016, a concessionária demite 75\% do seu quadro de funcionários, sinalizando uma possível rescisão de contrato.

\section{2 \\ Movimentos Oportunistas}

Nesta seção, reutiliza-se as figuras 4 e 5 que são associadas à proposição 3 para exemplificar como, no caso estudado, a alteração contratual oportunista feita pelo GERJ intensifica o comportamento oportunista investidor. As figuras 9 e 10 abaixo, como antes, consideram o $R$ e $e$ os fluxo de receitas e as obrigações contratuais em investimentos, respectivamente. A Concessionária Maracanã é simbolizada por $\theta_{H}$ (por ter sido a vencedora da licitação) e o resultado esperado pelo GERJ nesta situação é dado por $W_{H}$.

A figura 9 ajuda a ilustrar o caso real da PPP do Maracanã. Após a proibição da construção dos estacionamentos e do shopping por parte do GERJ, a receita esperada do projeto cai de $\mathrm{R} \$ 42,8$ milhões/ano para $\mathrm{R} \$ 23,80$ milhões/ano, logo, há o movimento de $R_{H}^{*}$ para $\widehat{R}_{H}$ alterando as condições originais do contrato.

A figura 10 na sequência mostra como a concessionária reage à alteração contratual não realizando os investimentos necessários, dado que o complexo não receberia o mesmo volume de obras e adicionalmente, diminuindo ainda mais seu esforço pela renegociação contratual em que o volume decai de aproximadamente $\mathrm{R} \$ 22$ milhões para R \$ 9 milhões anuais ${ }^{17}$, ou seja, uma queda de $43 \%$ das receitas, porém, com uma redução de $59 \%$ na obrigação de investimentos. Na figura 10 a diminuição de esforço é exibida no movimento de $e_{H}^{*}$ para $e_{L}^{*}$.

\footnotetext{
${ }^{17}$ Divide-se os valores apresentados pelo tempo de concessão de 35 anos atualizado em valores de 2013
} 


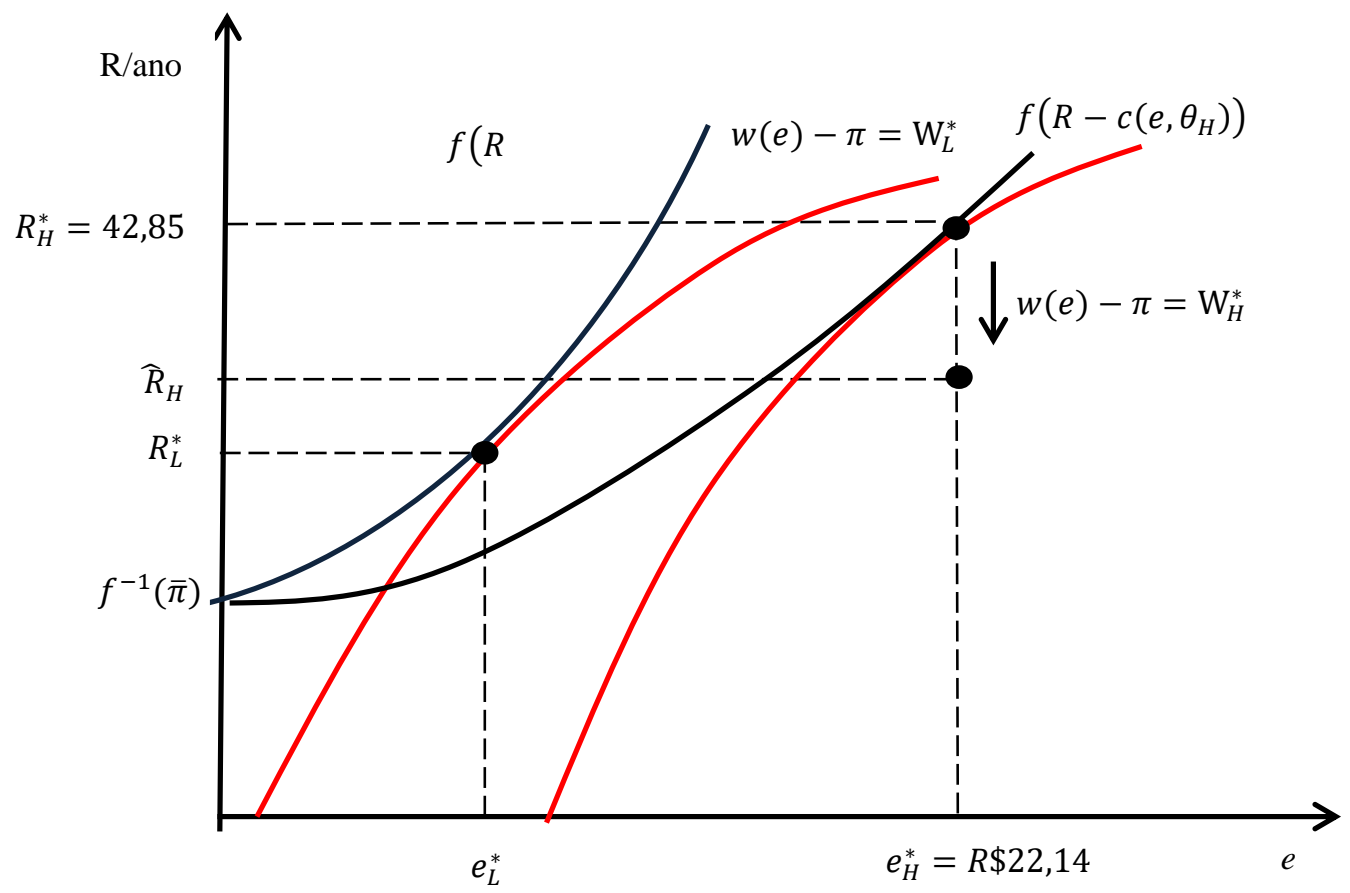

Figura 9 - Alteração contratual do GERJ nas receitas do Maracanã

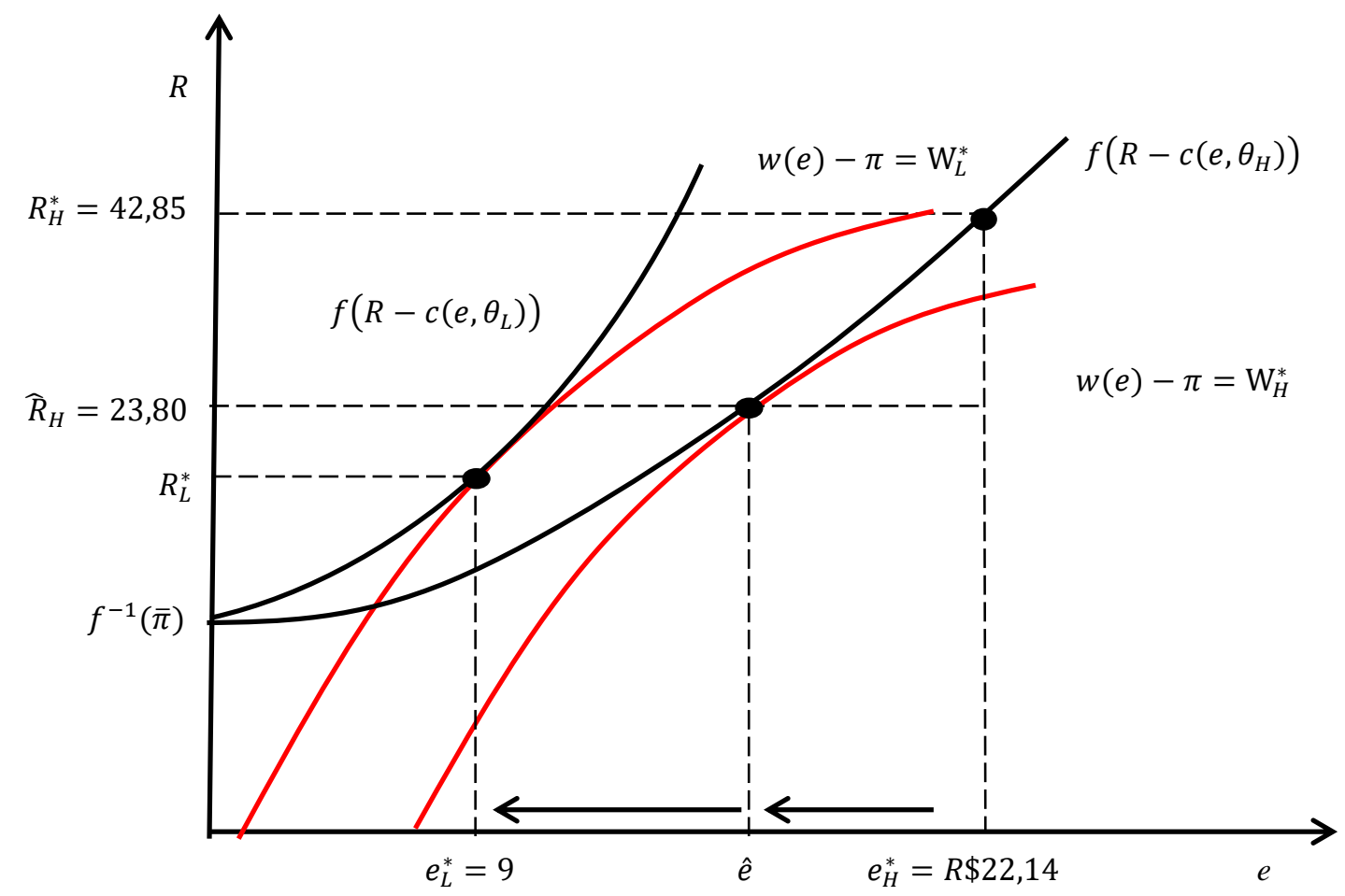

Figura 10 - Movimento Oportunista da Concessionária Maracanã.

Portanto, as figuras 9 e 10, corroboram com a proposição 3 ao demonstrar que no jogo agente-principal, o movimento oportunista por parte do governo reforça a resposta oportunista por parte do investidor. No caso Maracanã, o 
movimento do governo coibindo a mudança no complexo prejudicou o potencial de receitas. Consequentemente, a concessionária reage de modo oportunista, dado que na rediscussão contratual, o valor de seu esforço, sofreu uma queda proporcionalmente mais acentuada do que a perda de suas receitas.

Pode-se, também, analisar o caso Maracanã reforçado pela proposição 4, supondo duas situações:

(i) A Concessionária Maracanã é um agente $\theta_{L}$;

(ii) A Concessionária Maracanã é um agente $\theta_{H}$.

Na situação (i), a concessionária é na verdade $\theta_{L}$ e o contrato do GERJ não estabelece $\hat{e}_{L} \leq e_{L}^{*}$, a restrição (9.d) mostra que o par ótimo para $\theta_{L}$ é $\left(e_{L}^{*}, R_{L}^{*}\right)$. No entanto, ao remeter a figura 6 , vê-se que a concessionária oportunista escolhe $\left(\hat{e}_{L}, \hat{R}_{L}\right)$. Assim, o custo marginal de $\hat{e}_{L}$ aumenta mais do que seu ganho por receitas $\hat{R}_{L}$, como indica a curva tracejada do comportamento oportunista. No longo prazo, a seleção incorreta do agente, acarreta em renegociação de contrato com novos parâmetros reduzidos de investimento.

Na situação (ii), a concessionária é na verdade, $\theta_{H}$ e o contrato do GERJ não estabelece $e_{H}=e_{H}^{*}$. Para $\theta_{H}$ a restrição (9.c) mostra-se que o par ótimo para $\theta_{H}$ é $\left(e_{H}^{*}, R_{H}^{*}\right)$. O bem-estar ótimo para o governo é estabelecido na solução $W^{\prime}\left(e_{H}^{*}\right)=$ $c_{e}\left(e_{H}^{*}, \theta_{H}\right)$. Remetendo à figura 7 , se o contrato evita que a concessionária realize $e_{H}^{*}$, cria incentivos para reduzir seus investimentos atuando de modo oportunista. $\mathrm{Na}$ figura mencionada, esta movimentação é destacada pela curva oportunista que passa pelo lócus $\left(e_{H}^{*}, \widetilde{R}_{H}\right)$ e também por $\left(e_{L}^{*}, R_{L}^{*}\right)$ gerando bem-estar inferior $\widetilde{\mathrm{W}}_{H}, \mathrm{~A}$ concessionária por saber que a redução de esforço saindo de $e_{H}^{*}$ para $e_{L}^{*}$ é proporcionalmente maior do que a perda de receita de $\widetilde{R}_{H}$ para $R_{L}^{*}$.efetiva o seu oportunismo na renegociação contratual com novos parâmetros. Deste modo, o contrato ótimo, além de realizar a correta triagem, deve obrigar o investidor selecionado a manter um nível de desempenho contratado.

Portanto, pelo caso avaliado, podemos evidenciar que: (i) os mecanismos de incentivos podem revelar, junto à construção de cláusulas contratuais críveis, informações explicitas de potenciais investidores na PPP; (ii) O edital deve 
classificar os investidores por $\theta_{H}$ ou $\theta_{L}$. Ou seja, o parâmetro $\theta_{i}$ denota um conjunto de características exigidas pelo governo no contrato inicial, que tornam um investidor um efetivo concorrente; (iii) O oportunismo do governo em ações expost pode levar descrédito ao processo da PPP, pois, mesmo que o edital detenha mecanismos de incentivos, a ação oportunista pode conduzir a relação entre os entes públicos e privados a desgastantes renegociações ou a rescisão do contrato. 


\section{5 Jogo de Renegociação Financeira da PPP}

O capítulo precedente apresentou ações oportunistas no modelo agenteprincipal para PPPs. O caráter estático do modelo exibe uma relação limitada da dinâmica entre governo e investidor. Em condições de renegociação, a relação dinâmica entre governo e investidor se torna mais evidente. A renegociação oferece um cenário em que várias informações significantes são reveladas. Tais informações podem levar a uma continuidade do relacionamento de longo prazo entre as partes ou até mesmo a rescisão contratual. Para melhor destacar a interação dinâmica agente-principal, expõem-se aqui as principais premissas que formatam o modelo de renegociação de Ho (2006) e suas configurações.

Inicialmente, o modelo parte de três premissas básicas na renegociação da PPP:

(i) o contrato não especifica qualquer resgate do governo ou subsídios em face de uma crise financeira;

(ii) a legislação não proíbe o governo de socorrer o projeto de PPP, fornecendo uma garantia de dívida; e

(iii) o governo não é incentivado a resgatar um projeto sem razões justificáveis (Por exemplo, custos excessivos ou perdas de receitas ocasionadas por gestão ineficiente).

A figura 11 mostra o jogo original de Ho modificado através de algumas considerações neste trabalho. O jogo é iniciado pelo investidor e este pode adotar duas estratégias: jogar "abandonar projeto" ou "subsídio". A partir de um cenário adverso, o investidor pode abandonar o projeto ou pedir subsídios $\$ U$, que é considerado como o subsídio máximo possível. Se o investidor decide abandonar o projeto, o payoff, respectivamente, de investidor e do governo é $[-0 ;-n(B)]$, onde: (i) $-n(B)$ é o custo político devido ao lançamento do projeto e; (ii) $B$ mede o gasto excessivo do orçamento público quando um projeto está em falência. Se o investidor decidir abandonar o PPP, o modelo descreve que a recompensa será $-\delta$. 
Para a construção desta recompensa, o autor argumenta dois pontos: (i) o valor das ações tende a zero $(\delta \rightarrow 0)$ antes da falência do projeto, portanto, assumindo que $\delta$ $=0$. (ii) Apesar de considerar a perda de reputação, o jogo original considera que $\delta$ não é significativo, desta forma o investidor seria indiferente entre solicitar subsídios ou abandonar o PPP. No entanto, este estudo faz duas considerações que alteram parcialmente a configuração de payoffs do jogo de renegociação original, pois, na prática, um processo de renegociação envolverá, para o investidor: (a) custos operacionais (contratação de advogados, analistas econômicos, etc.) que são considerados um sunk cost; (b) custos burocráticos (elaboração de um contrato com novos parâmetros, aprovação por um tribunal de contas, etc.) que podem levar um tempo considerável, prejudicando a prestação de serviços públicos. No entanto, se o investidor decidir abandonar o PPP em sua primeira ação, os únicos custos assumidos são os de términos contratuais. Portanto, considera-se que o investidor não pode ser indiferente entre as duas situações. Assim, caracteriza-se $-\delta$ como a recompensa do investidor devido ao custo da abertura da renegociação. Portanto, a recompensa do investidor é zero se for decidida pela falência PPP. Do ponto de vista do governo, se um projeto PPP é considerado insolvente, é politicamente ou economicamente dispendioso. Portanto, o jogo de renegociação pressupõe que o governo rejeite a renegociação neste caso.

A partir deste ponto, o governo pode jogar "negociar" ou "rejeitar". Se o governo jogar "rejeitar", declara-se a falência do projeto e outro edital de licitação deve ser feito. Portanto, a recompensa para ambas as partes será $[-\delta ;-n(B)]$. Caso governo escolha negociar, os payoffs de investidor e governo são respectivamente: $[g U ;-m(g U)]$, definindo-se: (i) $m$ é o custo político devido ao subsídio de resgate ao investidor; (ii) $g$, como percentual de $\$ U$, onde $0 \leq g \leq 1$. No entanto, este trabalho, devido às mudanças feitas nos payoffs de rejeição do governo, também modifica o limite inferior desse intervalo para a sentença estrita $0<g \leq 1$. (As condições formais deste intervalo serão explicadas na subseção 6.2). Cabe ressaltar as diferenças entre as funções $m$ e $n$. A primeira ocorre pelo custo político de se renegociar mais subsídios ao investidor original da PPP. A segunda se refere ao custo político de alocar mais subsídios em um projeto que será relicitado (ou seja, há um custo de relicitar o projeto devido ao serviço não prestado até ter um novo ganhador). Ou seja, ambas as funções retratam os gastos excessivos 
do governo com subsídios no projeto e que estão sujeitos a criticas. No jogo da figura 11, a linha em negrito mostra o ENPS que gera menor custo político para o governo. A configuração formal de todos os possíveis equilíbrios será demonstrada na próxima seção.

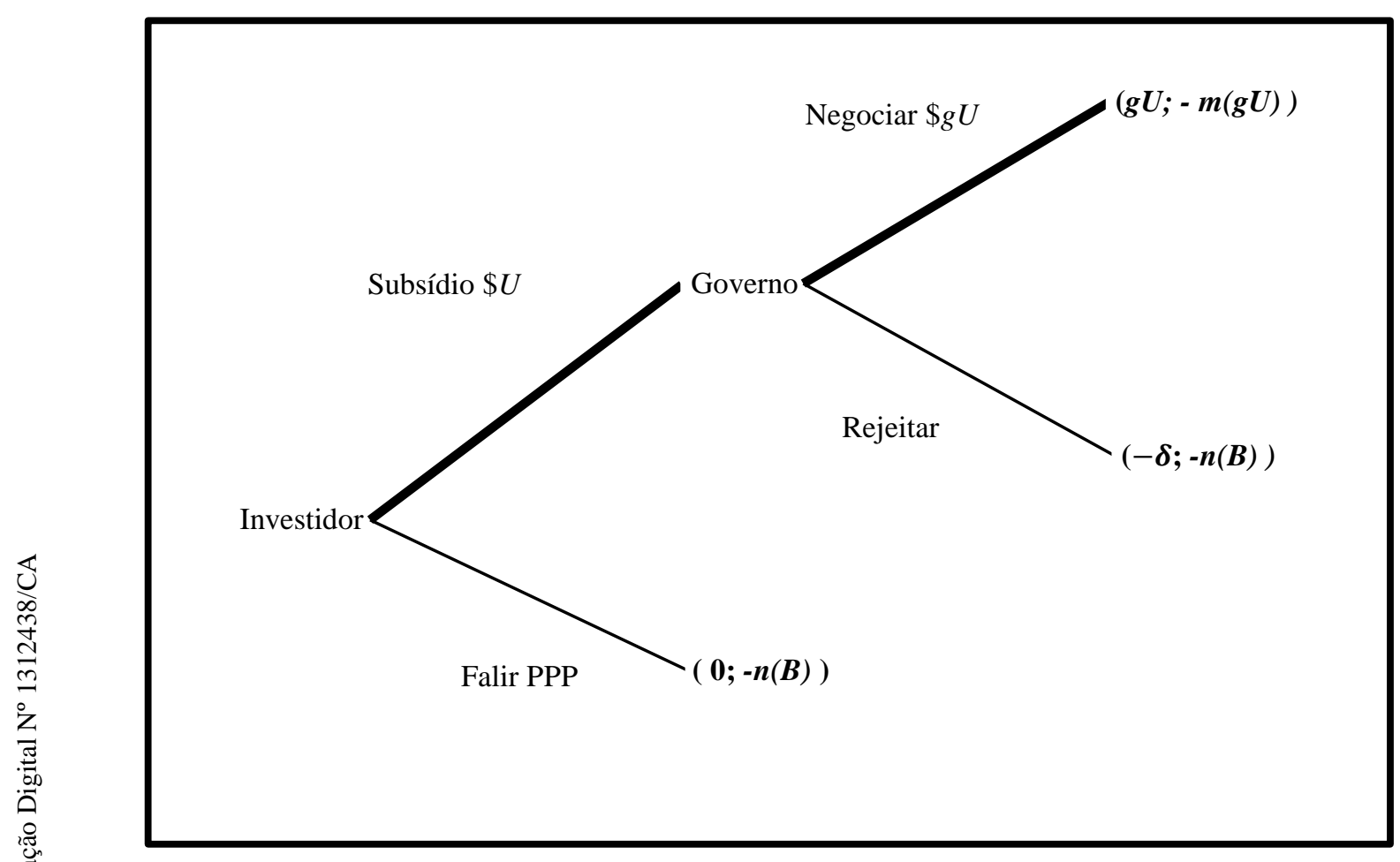

Figura 11 - Jogo de renegociação da PPP modificado.

\section{1. \\ Analise do Equilíbrio de Nash no Jogo de PPP}

Esta seção descreve com maior formalidade os aspectos fundamentais do modelo de renegociação, analisando o jogo da figura 11 de maneira recursiva que determina o Equilíbrio de Nash Perfeito em Subjogos (ENPS). O modelo de Ho desenvolve três candidatos à ENPS. No entanto, na estrutura deste estudo, dado $\delta>0$, refina-se o conjunto de soluções originais, de modo que apenas dois ENPS permanecem viáveis. 
Caso 1: O governo negocia se os retornos da negociação forem maiores do que os de rejeição. O equilíbrio de resgate é obtido, com a condição- $m(g U)>$ $-n(B)$. Logo:

$$
m(g U)<n(B)
$$

Posto as diferenças das funções $m$ e $n$ anteriormente, para o governo se torna menos dispendioso (custo político), negociar subsídios à PPP com o investidor inicial do que relicitar o projeto para outro investidor. Portanto, garantindo o payoff para investidor e governo, respectivamente, $[g U ;-m(g U)]$ na figura 11 (destacado pela linha em negrito). Para achar a solução final desta condição, retroage-se ao nó "subsídio" e ao comparar seus possíveis payoffs, dado que $g U>0$ o investidor joga "subsídio". A linha em negrito na figura 11 destaca que é sempre benéfico ao investidor negociar subsídio se a equação (11) for satisfeita. $\mathrm{O}$ intervalo de oferta de renegociação é expresso por:

$$
g U \in\{g U: g U>0, m(g U)<n(B)\}
$$

Portanto, o ENPS é a estratégia [Subsídios; Negociar], ou seja, a solução de resgate da PPP, posto que $n(B)-m(g U)>0$.

Caso 2: Se (11) não for satisfeita, o governo joga "rejeitar". Retroagindo-se ao nó do investidor, dado que há custos adicionais para o investidor na exigência de subsídios $(-\delta)$, o investidor prefere rigorosamente "falir PPP" ao subsídio. Assim, diferente de Ho (2006), o único ENPS é [Falir PPP, Rejeitar]. Se o investidor decidir jogar "PPP falido", isso significa que ele prevê que o governo jogará "rejeitar". Assim, para o governo, o custo político de aplicação da PPP é menor do que renegociá-lo, e este ENPS é alcançado se:

$$
m(g U)>n(B)
$$

Se a condição de (13) é satisfeita, se pode obter a solução de não-resgate do projeto, gerando:

$$
n(B)-m(g U)>0
$$

Sendo assim, as condições geradas das equações (11) e (13) são chamadas de soluções de resgate e não-resgate no modelo, respectivamente, e dependem 
diretamente de o governo mensurar o custo politico de aceitar ou não a renegociação em cada situação.

\section{2.}

\section{Custo Político caso o governo jogue "Negociar”.}

As configurações iniciais destacadas no modelo de renegociação que o custo político para o governo poderá depender de diversos fatores como, por exemplo, se o governo estiver findando seu mandato e pretende uma reeleição, este fica mais sujeito a renegociar o projeto. Logo, o modelo insere características que podem ser analisadas em algumas condições.

Se o governo decide negociar com o investidor, o custo político é dado por:

$$
m(g U)= \begin{cases}\beta(g U), & \text { se } g U \leq J \\ \beta(g U)+\rho_{s}(g U), & \text { se } g U>J\end{cases}
$$

Onde: (i) J é o subsídio justificável, ou seja, um tribunal de contas pode analisar este pedido sem que o governo seja criticado por excessivos subsídios; (ii) $\beta(g U)$ representa o custo político de gastos excessivos do orçamento e; (iii) $\rho_{s}(g U)$ é o custo político de excessivos subsídios, em que o subscrito $s$ denota subsídio. Baseado no conceito de escassez de recursos públicos a equação (15) torna o custo político de renegociação uma função estritamente crescente dos gastos, isto é, $\forall g U>g U^{0}: m(g U)>m\left(g U^{0}\right)$. A partir de $J$ os custos políticos de subsídios excessivos $\rho_{s}(g U)$ aumentam o custo político da renegociação para o governo, ou seja, até $J, \rho_{s}(g U)=0$ porque $g U \leq J$. Acima dessa condição, o governo está renegociando subsídios fora dos parâmetros definidos no contrato inicial e o custo politico adicional é dado por $\rho_{s}(g U)$.

\section{3.}

\section{Custo Político caso o governo jogue "Rejeitar".}

Neste tópico, destacam-se as configurações do modelo de renegociação de Ho na ocorrência do governo jogar "rejeitar" na negociação da PPP e como se dá o custo politico. 
Se o governo decide rejeitar a renegociação, então é definida a falência do projeto e a concessão é devolvida ao setor público. A partir disso, o governo tem duas alternativas: ficar com o projeto falido, sinalizando à opinião pública uma escolha errada na alocação de recursos públicos, ou reabrir um processo de licitação para novos investidores. A segunda alternativa impõe maiores restrições ao governo. A relicitação de uma PPP pode ocorrer por diversos fatores: insolvência do projeto devido à má gestão, desenho de contrato ineficiente e, em casos mais extremos, corrupção, etc. A maioria das concessões tem um percentual elevado de captação de recursos de terceiros, em particular, bancos comerciais. Ho afirma que os bancos ficam extremamente avessos em disponibilizar novos ou adicionais empréstimos $^{18}$. Deste modo, a única forma na qual se poderia mitigar esta aversão por parte dos bancos, seria o governo relicitar a PPP emitindo garantias sobre dívidas. No entanto, o governo se expõe a maiores custos políticos, dado que tais garantias são subsídios a um projeto que já se encontra sobre críticas, assim, descreve-se:

$$
B=G+\tau
$$

Em que G é o subsídio mínimo exigido que sinalize ao banco emprestador apoiar um projeto problemático, e $\tau$ é o custo de oportunidade de substituir o investidor original ${ }^{19}$. Logo, o custo político de relicitar o projeto é modelado:

$$
n(B)=\beta(B)
$$

Que podem incluir o custo de relicitar o projeto, o custo de interrupção devido à falência e o processo relicitação. A equação (17) se reescrita, se torna:

$$
n(G+\tau)=\beta(G+\tau)
$$

18 Neste estudo, não se faz referências a bancos de desenvolvimento que trabalham com taxas subsidiadas como o BNDES, só se refere a bancos comerciais. Porém, mesmo com bancos de fomento, como no caso brasileiro, o governo fica sujeito a críticas por usar bancos públicos subsidiando projetos problemáticos.

$19 \mathrm{O}$ custo de oportunidade de substituir o investidor original é vinculado à defasagem que existe entre o momento que o investidor original decide pela rescisão do contrato e o momento que um novo investidor assume a PPP. Neste interstício, o governo precisa refazer um novo edital, revisar cláusulas contratuais, a aprovação do tribunal de contas, etc. Isso pode prejudicar substancialmente o fornecimento de serviços públicos. 
A figura 12 exibe para um $\tau$ fixo a função $n(G+\tau)$ sendo descrita de forma diferente de $n(G)$, sendo deslocada para esquerda por $\tau$. Isto é, mostra que mesmo uma diminuição de $G$, no mínimo, não altera o custo de oportunidade de substituir o investidor. As características das funções do modelo de renegociação de Ho são apresentadas no apêndice deste trabalho, porém, utilizadas para descrever o EN refinado.

$n(G+\tau), n(G)$

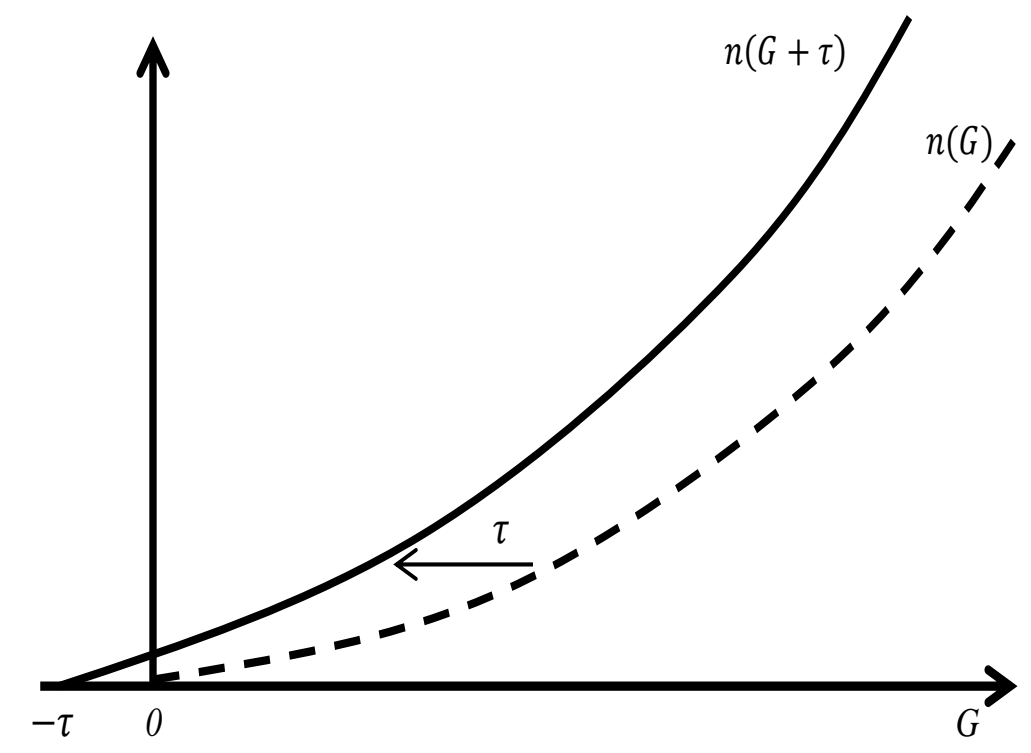

Figura 12 - Função do custo político de relicitação da PPP (Fonte: Ho, 2006).

\section{4.}

\section{Refinamento do Equilíbrio de Nash}

O modelo de Ho define cinco características matemáticas de parâmetros para PPPs (apresentadas no apêndice deste trabalho). A característica 1 dos parâmetros da PPP define $g U \geq G$. Logo, ao reutilizar a condição (11), tem-se que, na renegociação:

$$
m(g U)<n(B), \quad g U \geq G
$$

Reordena-se (19), posto que o custo de oportunidade de substituir o investidor original é $\tau \geq 0$ e $J \in[0, U]$ : 


$$
m(g U)<n(G+\tau), \quad g U \geq G
$$

O modelo define que o limite inferior de $g U$ para recuperar um projeto com dificuldades financeiras é dado por $g U \geq G$. Para o limite superior, a condição em (20) define que a renegociação entre governo e investidor não ultrapasse o custo político da relicitação da PPP para o governo dado por $n(G+\tau)$, portanto, limite superior de $g U$ pode ser obtido através da resolução de $n(G+\tau)-m(g U)=0$. Assim, reorganiza-se:

$$
g U \in\left\{g U: G \leq g U \leq m^{-1}[n(G+\tau)]\right\}
$$

A equação (21) cria uma zona de oferta de renegociação (ZOR), em que $m^{-1}[n(G+\tau)]$ é a função inversa de $m$ que cria um limite superior de $g U$ que respeita a condição imposta por (20), isto é, significa que a margem de renegociação entre governo e investidor privado pode ir até o ponto em que, para o governo vale a pena o custo político de renegociar o projeto sem a necessidade de repropor para outro investidor, como exibe figura 13.

O modelo de renegociação para PPPs de Ho define condições de equilíbrio em cada situação do jogo exposto na figura 11, mostrando como governo e investidor alteram seus payoffs diante de cada ação estratégica do jogo. Limita-se o espaço de renegociação do contrato que seja ótimo para o governo negociar, a quantidade de subsídio $g U$. O ENPS da árvore do jogo por retroindução para investidor e governo é, respectivamente, [subsídios; negociar].

A síntese do modelo de renegociação de Ho (2006) apresentado neste capitulo, mostrou: (i) como ocorre a interação dinâmica de renegociação entre governo e investidor; e (ii) que o melhor resultado para o governo em termos de custo político é denotado pelo ENPS de resgate do projeto. Apesar destas vantagens, têm-se as seguintes limitações: (i) a discussão sobre o tipo de investidor selecionado, que na fase de negociação pede ao governo subsídios para melhorar a viabilidade financeira do projeto; e (ii) a suposição sobre o jogo ser de informação completa. Ho \& Tsui (2010) destacam que, geralmente, o setor público dificilmente nega pedidos de subsídios dos investidores em renegociações. Consequentemente, deixando o governo com pouca margem de contraoferta e permitindo subsídios excessivos. 


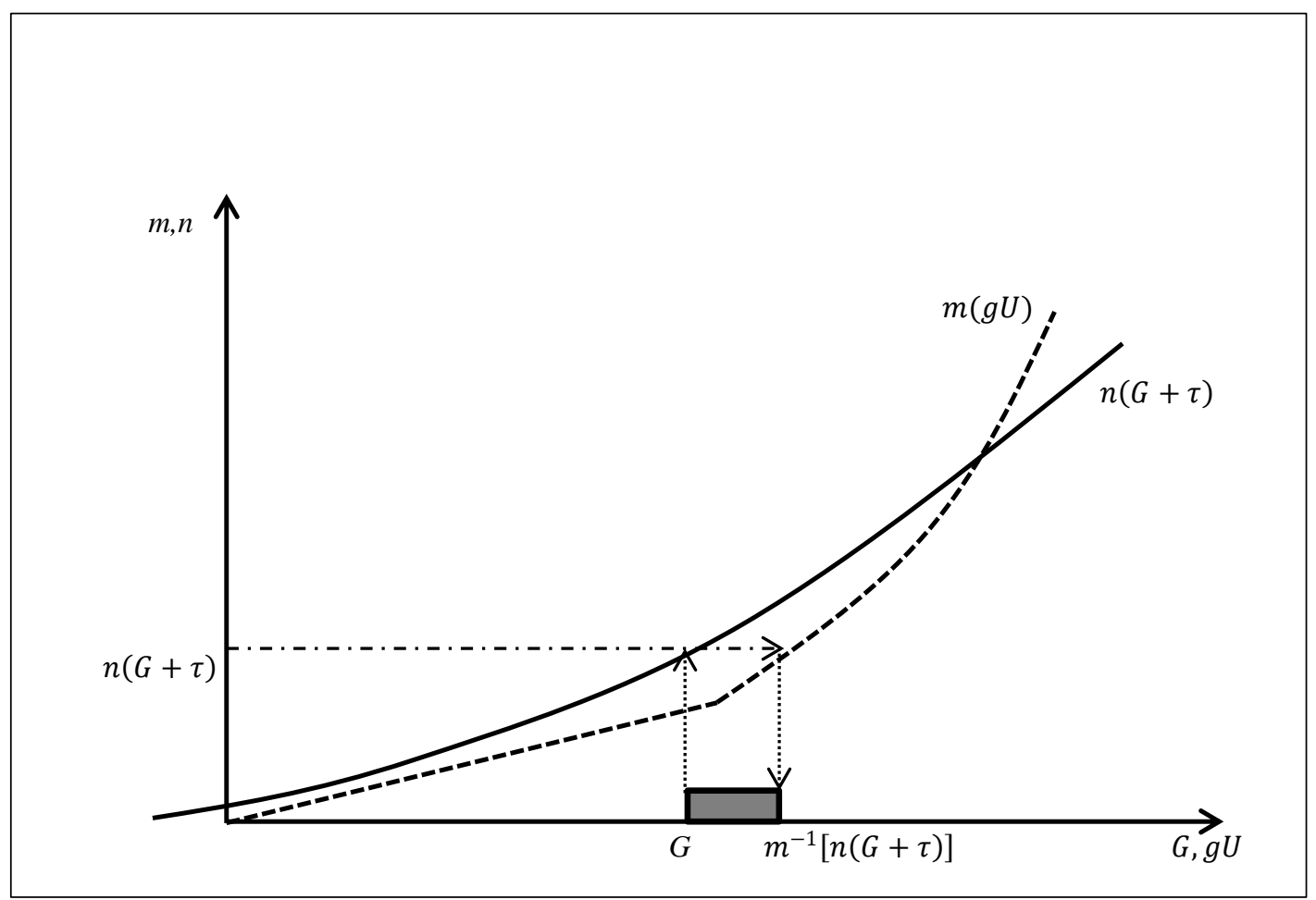

Figura 13 Zona de Oferta de Renegociação (Fonte: Ho, 2006)

Baseado nesta condição, a proposta deste estudo a partir desta etapa é demonstrar como os mecanismos de incentivos, ao melhorar a seleção de investidores como condição ex-ante, permite: (i) minimizar os impactos para o governo com pouca margem de contraoferta na fase de renegociação; (ii) demonstrar que ao selecionar o investidor $\theta_{H}$, tal condição reforça o ENPS de resgate da PPP; e (iii) demonstrar que um edital sem mecanismos de incentivos, permite a seleção do investidor $\theta_{L}$ e suas condições de produtividade não são sustentáveis na renegociação. 


\section{6. Mecanismos de Incentivos e Renegociação}

Dentre os campos de estudo que as PPPs têm oferecido como objeto de investigação, o tema de renegociações contratuais tem sido o mais negligenciado. Igualmente, o campo de mecanismos de incentivos é um ramo ainda pouco explorado para desenhar contratos de PPPs. A área de incentivos tem como vantagem, delinear contratos que evitem comportamentos indesejáveis em condições de assimetria de informação. As relações a serem exibidas pretende contribuir para o aprimoramento de contratos, pois, parte-se da premissa de que a capacidade gerencial do investidor, selecionado na concessão, altera consideravelmente as condições de renegociação posteriormente.

\section{1 \\ Contexto para renegociação de PPPs}

Como visto, um contrato bem desenhado adiciona restrições que direcionam o investidor a revelar a verdade sobre seu tipo produtivo. Incentivos corretos fazem o investidor manifestar diretamente sua capacidade técnica e financeira de operar um projeto. Caso o contrato não defina as condições para melhor seleção, um investidor $\theta_{L}$ pode ganhar a concorrência através de um lance superestimado, seja inflando receitas ou minimizando custos (bid oportunista). Posteriormente, a insustentabilidade refletida na manutenção de custos, leva o investidor de baixa capacidade, mesmo que o governo garanta alguma forma de subsídios, a solicitar subsídios extras.

Este trabalho utiliza a metodologia de mecanismos de incentivos do terceiro capitulo, para analisar e aprimorar o estudo feito por Ho (2006), um dos principais modelos de jogos de renegociações na literatura de PPP. O objetivo é demonstrar que as restrições de incentivos podem contribuir para melhorar os resultados deste jogo e quais são as mudanças ao se adotar um cenário em que a assimetria de informação se faz presente. 
Uma das premissas do modelo de Ho (2006), expostas no capitulo anterior, define que o governo não tem incentivo em resgatar uma PPP sem razões justificáveis. Por exemplo, custos excessivos ou perdas de mau funcionamento ocasionado por gestão ineficiente. A principal questão levantada por esta premissa é, como minimizar problemas da gestão ineficiente da parte privada. Em médio prazo, a ineficiência pode acarretar em: (a) renegociações não previstas; (b) volumes de subsídios não esperados pelo governo assim como sua frequência; (c) queda de bem-estar ocasionada pela piora do fornecimento dos serviços públicos e; (d) rescisão contratual. Todos estes fatores podem contribuir para aumentar as críticas sobre a credibilidade do governo através do custo político.

Nesta etapa, sugere-se que a modelagem de renegociação possa ser aperfeiçoada, acrescentando mecanismos de incentivos no edital da concessão como condição ex-ante. A finalidade das restrições de incentivos é mostrar que o edital pode selecionar investidores com melhor capacidade gerencial. Deste modo, evitam-se renegociações excessivas ou oportunistas com subsídios que ultrapassem o limite justificado por Ho (2006), conduzindo ao término antecipado do contrato. Um governo maximizador de bem-estar deve realizar uma triagem correta dos participantes da licitação gerando um contrato com equilíbrio separador. Impõe-se a premissa que um contrato sem mecanismos de incentivos, permite a seleção do gestor de baixa capacidade gerencial e, consequentemente, possibilite uma futura renegociação realizada com subsídios excessivos. Para demonstrar as condições sob o cenário de renegociação, este estudo reutiliza a metodologia de Mas-Colell et al (1995), apresentada anteriormente.

Conforme destacado, a renegociação no PPP pode ser iniciada, essencialmente, por duas razões: primeiro, pelas condições do contrato original. Ou seja, a partir da assinatura do contrato, o governo e a concessionária sabem que, em cada período, as cláusulas contratuais podem ser ajustadas. O segundo está relacionado ao desvio ético das partes do contrato. Este estudo define o comportamento oportunista como uma característica do desvio da ética contratual e pode ser iniciado pelo governo e / ou pelo investidor privado. A importância desta definição ocorre, em particular, por dois fatos: (i) Baseia-se na premissa de que o governo representa, em última instância, a sociedade civil no contrato de PPP; e (ii) o oportunismo do investidor privado também gera custos sociais mais elevados para 
a sociedade. No primeiro caso, os gerentes públicos podem ter comportamento antiético ao violarem cláusulas contratuais devido a interesses políticos, corrupção, etc. No segundo caso, este desvio ético causa prejuízos na prestação de serviços públicos.

\section{2 Abertura de renegociação de PPPs: 0 investidor selecionado}

No capitulo anterior, mostrou-se que o modelo de renegociação cria um limite de subsídios governamentais dado por $J$, que pode ser justificável tanto do ponto de vista financeiro quanto jurídico. O limite imposto por $J$ auxilia os parâmetros da Zona de Oferta de Renegociação (ZOR) fornecida pela equação (21). Na ZOR, cada vez que o volume de subsídios se aproxima do limite superior, torna a renegociação cada vez mais cara para o governo. Os limites da ZOR criam condições para que o governo possa mitigar riscos inerentes do projeto sem sofrer críticas de gastos excessivos da opinião pública.

Para que os subsídios se mantenham justificáveis, torna-se necessário, então, criar condições no processo de licitação para que a renegociação contratual não se torne recorrente e desnecessária e, consequentemente, levando descrédito a todo o processo de concessão. Pelas considerações matemáticas descritas no terceiro capítulo deste trabalho, o contrato de PPP deve, no processo licitatório, gerar um equilíbrio que separe os agentes de baixa e alta produtividade. Assim, o governo deve preferir estritamente o investidor de alta produtividade, posto que $\theta_{H}>\theta_{L}$. O Lema 1 resume esta condição:

Lema 1: Um contrato de PPP gerador do equilíbrio separador, determina a solução ótima para o governo que evita renegociações oportunistas. O equilíbrio separador ocorre ao selecionar um investidor $\theta_{i}$ no qual $c_{e}\left(e, \theta_{j}\right)>c_{e}\left(e, \theta_{i}\right)$ para $i \neq j$ que atenda $w^{\prime}\left(e_{i}^{*}\right)=c_{e}\left(e_{i}^{*}, \theta_{i}\right)$.

A figura 14 exibe quer seja para $\theta_{L}$ ou $\theta_{H}$, pontos mais acima e a esquerda coloca o investidor $\theta_{i}$ em uma posição melhor. O governo está melhor quando se move no sentido oposto. $\mathrm{O}$ bem-estar alcançado pelo governo deve ser exatamente 
igual a distancia da origem até o ponto no qual a curva de bem-estar que passa pelo ponto $\left(e_{i}^{*}, R_{i}^{*}\right)$ atinge o eixo vertical. Portanto, como o contrato de equilíbrio separador exige maior esforço no estado $\theta_{H}$, o governo extrai maior bem-estar quando seleciona o investidor de alta capacidade.

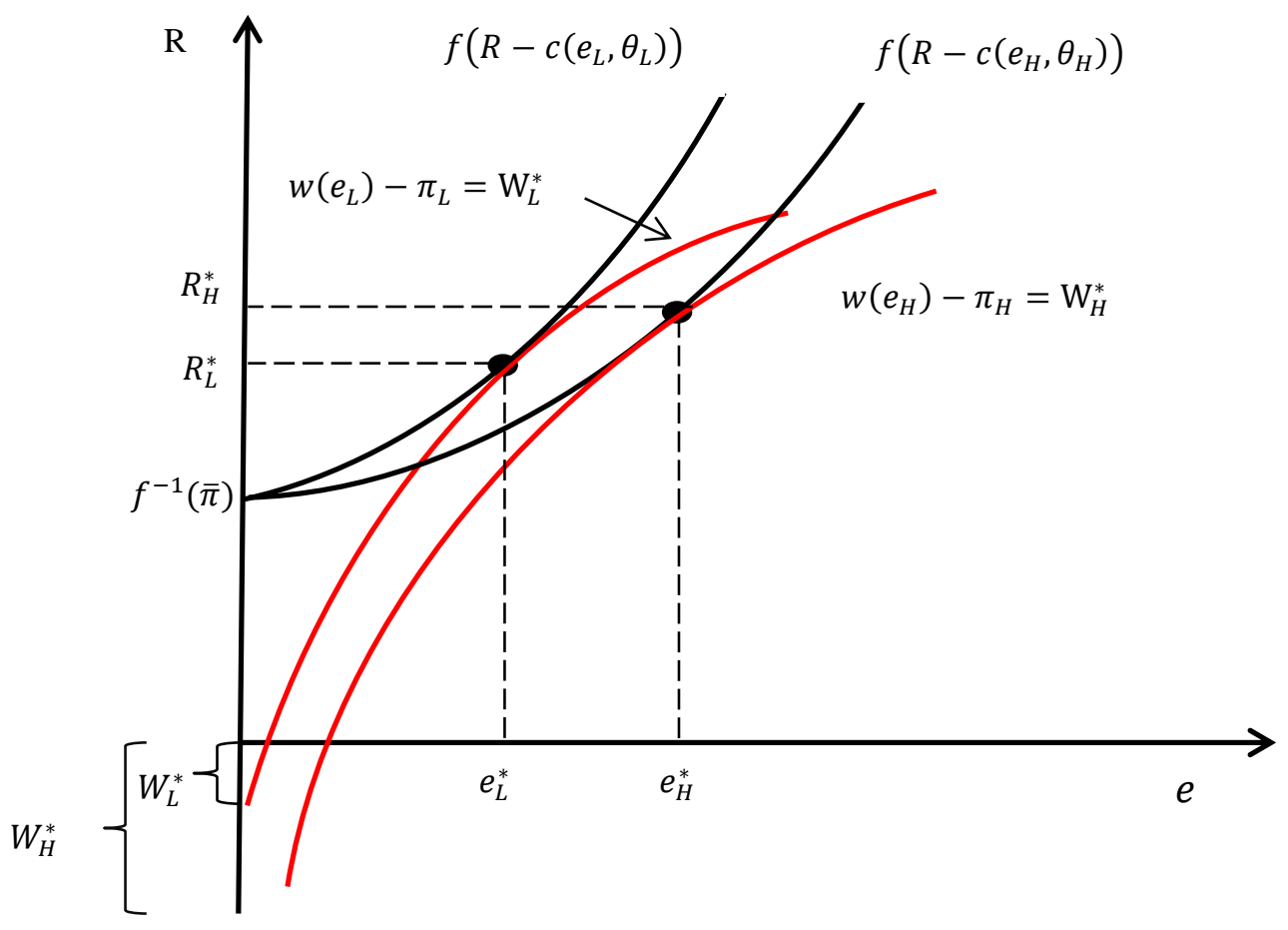

Figura 14 - Contrato Gerador de Equilíbrio Separador

A figura 15 expõe o proposto pelas restrições compatíveis com incentivos. A linha tracejada mostra que um edital que não impõe restrições de incentivos pode levar o investidor $\theta_{i}$ a atuar de maneira oportunista. Ao supor que $\theta_{L}$ vence a licitação, o vetor $(\tilde{e}, \tilde{R})$ mostra que a elevação de $c_{e}\left(e, \theta_{L}\right)$ é superior ao que $\theta_{L}$ pode manter ao tentar gerar um lucro $\tilde{\pi}$. A curva oportunista, indicada pela linha tracejada, mostra uma relação incongruente aos valores $\left(\tilde{e}_{L}, \tilde{R}_{L}\right)$ e $\left(e_{L}^{*}, R_{L}^{*}\right)$. Portanto, $(\tilde{e}, \tilde{R})$ é não factível dado o excessivo aumento dos custos em comparação ao aumento de receitas. Nesta condição, o jogo de renegociação indicaria que $\theta_{L}$ pode jogar "falir PPP" ao constatar que a elevação de seus custos se torne insustentável. O payoff do jogo torna-se $(0 ;-n(B))$ para investidor e governo, respectivamente. Logo, $-n(B)$, além de revelar o quão dispendioso é para o governo 
ter que relicitar a PPP, também mostra o custo de não empregar um mecanismo incentivo-compatível no edital.

Entretanto, se $\theta_{L}$ joga "Subsídios" $\$ U$, o governo tem duas alternativas: rejeita o pedido de $\theta_{L}$ gerando payoff $(-\delta ;-n(B))$ ou negocia o pedido de subsídios para manter o projeto viável. A quantidade $g U$ que o governo deve fornecer para manter a PPP original deve cobrir os custos de $\theta_{L}$ ter se comportado oportunisticamente. Porém, o limite superior da ZOR impõe que $g U \leq$ $m^{-1}[n(G+\tau)]$ e pode ser superado neste caso. Deste modo, o ENPS do jogo de renegociação pode ser alterado caso o governo esteja jogando com $\theta_{L}$.

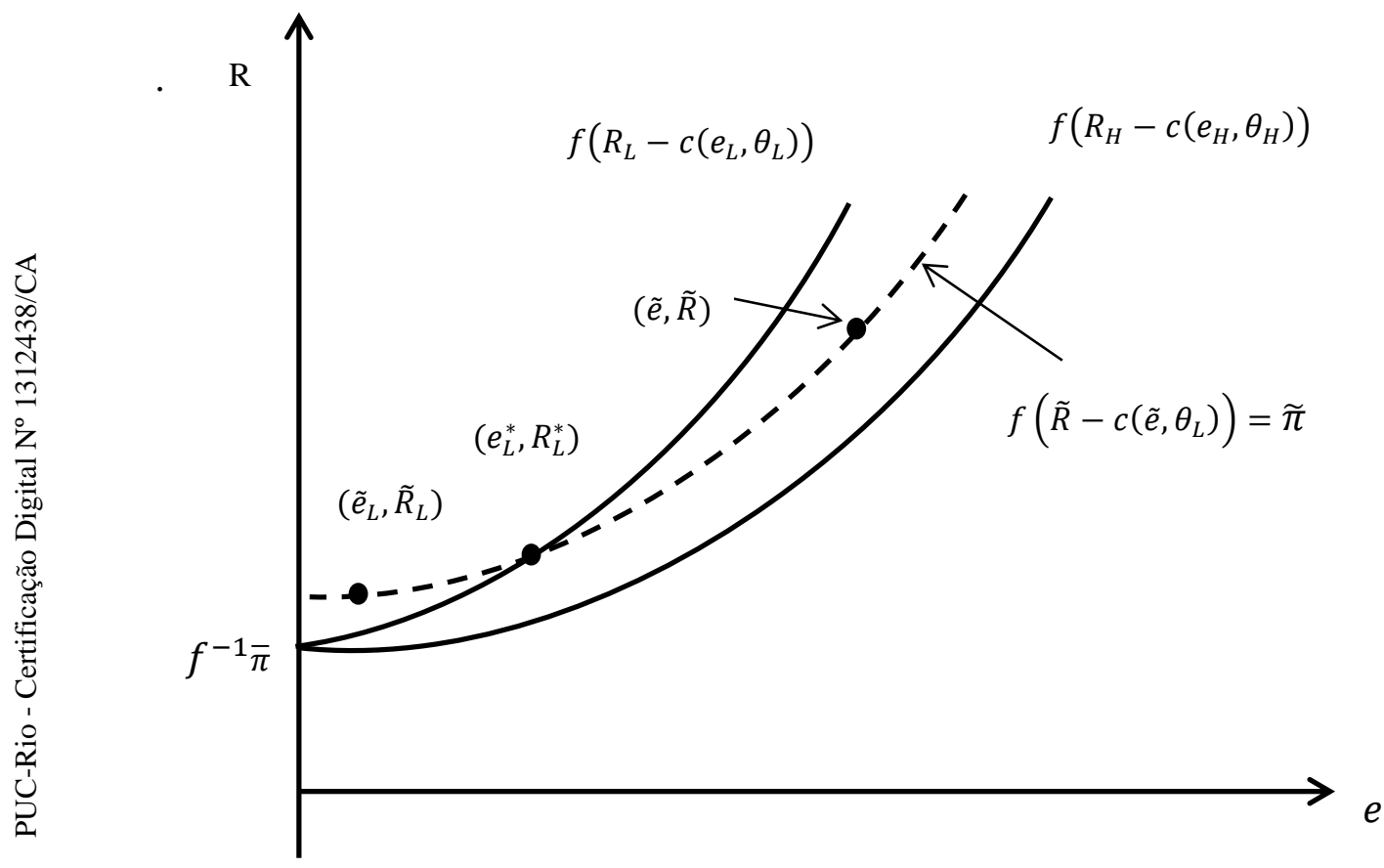

Figura 15 - Comportamento oportunista de $\theta_{L}$ na PPP

O item (i) da Proposição 3 é reutilizado para analisar o comportamento oportunista nesta etapa. A figura 16 exibe a trajetória que percorre $f\left(R-c\left(e, \theta_{L}\right)\right)$ de $\left(R_{L}^{*}, e_{L}^{*}\right)$ até $\left(\hat{R}_{L}, \hat{e}_{L}\right)$ mostrando o aumento de custos para $\theta_{L}$ através do conjunto de setas sobrepostas. Por não conseguir suportar um esforço acima de sua capacidade, $\theta_{L}$ verifica uma aceleração de custos proporcionalmente maior do que o aumento de receitas, que o conduz a pedir renegociação. Pode-se afirmar, portanto, que o vetor $\left(\hat{R}_{L}, \hat{e}_{L}\right)$ indica o ponto de abertura do pedido de renegociação. Ou seja, o fato da triagem incorreta admitir um $\theta_{i}$ de baixa capacidade, acarreta em 
aumento das chances de renegociação. Portanto, para que tal situação fique explícita, o Lema 2 caracteriza, sinteticamente, as condições para o pedido de renegociação do $\theta_{i}$ de baixa capacidade.

Lema 2: A participação de investidor $\theta_{L}$ na PPP, implica que este realiza um esforço acima da capacidade sustentável $e_{L}^{*}$. A condição de custos não sustentável $\widehat{e_{L}}$ leva $\theta_{L}$ a pedir negociação de subsídios excessivos em termos de custo político.

Prova: Pela restrição (9.d), o vetor $\left(e_{H}, R_{H}\right)$ deve se situar sobre ou abaixo da curva $f\left(R-c\left(e, \theta_{L}\right)\right)$. Pela restrição (9.c), o vetor $\left(e_{H}, R_{H}\right)$ deve se localizar sobre ou acima da curva $f\left(R-c\left(e, \theta_{H}\right)\right)$ que passa por $\left(\widehat{e}_{L}, \hat{R}_{L}\right)$. Sendo assim, o par $\left(e_{H}, R_{H}\right)$ deve ficar em qualquer área da região sombreada da Figura 16. Esta condição implica que o ponto $\left(\widehat{e_{L}}, \widehat{R}_{L}\right)$ demonstra a realização de esforço excessivo de $\theta_{L}$. Tal condição de custos desrespeita o Lema 1 e a restrição de incentivos $R_{L}-c\left(e_{L}, \theta_{L}\right) \geq R_{H}-c\left(e_{H}, \theta_{L}\right)$.

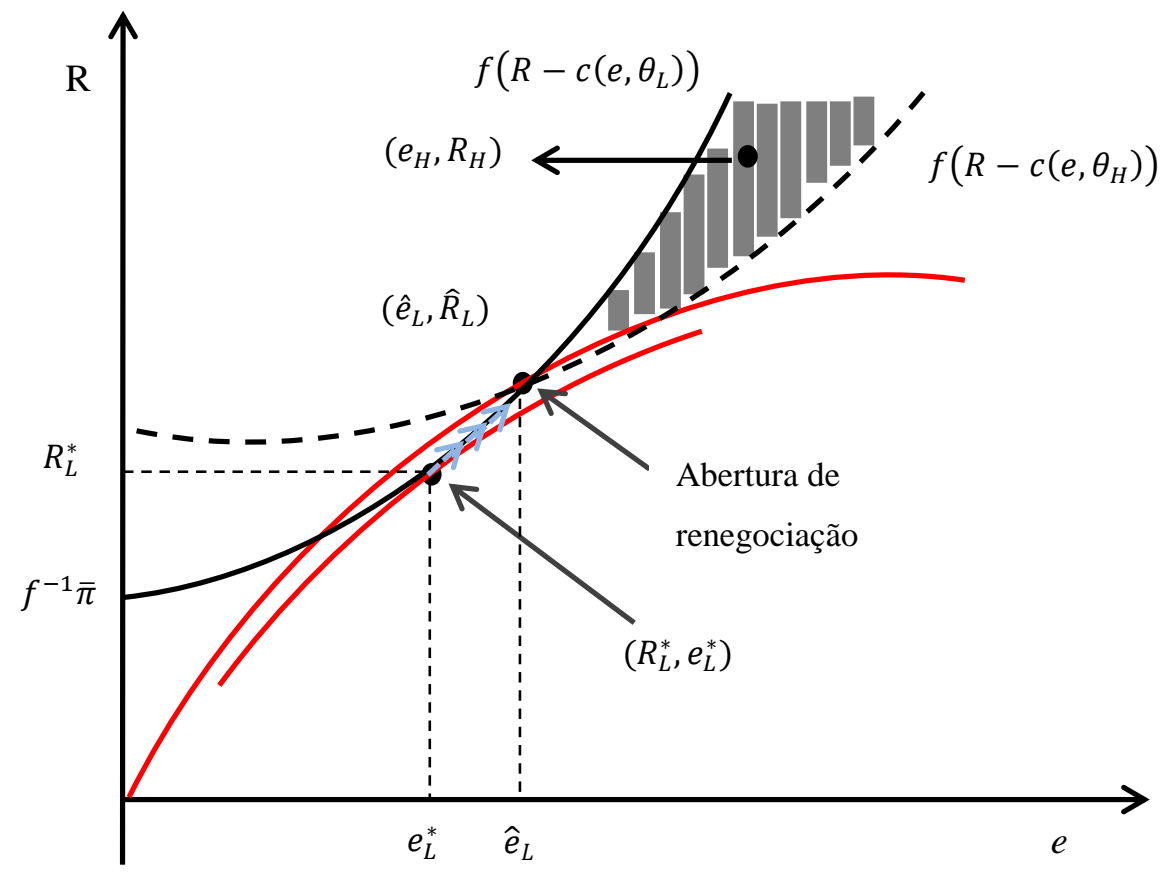

Figura 16 - Realização de esforço não sustentável de $\theta_{L}$.

Nesta situação, $\theta_{L}$ verifica o aumento de $c_{e}\left(e, \theta_{L}\right)$ gerado por $\hat{e}_{L}$. Consequentemente, o governo se depara com um cenário não configurado pelo 
modelo de Ho: o tipo $\theta_{i}$ que será beneficiado com subsídios se revela somente na renegociação.

Pela árvore de renegociação de Ho, a situação de esforço insustentável pode conduzir $\theta_{L}$ a jogar "falir PPP" $(0 ;-n(B))$. Retomando a figura 11, pelo lado superior da árvore, $\theta_{L}$ pode jogar "pedir subsídios". No entanto, este jogador deve verificar se $\$ U$ é suficiente para cobrir o aumento em $c_{e}\left(e, \theta_{L}\right)$ gerado por $\hat{e}_{L}$. Sequencialmente, o governo pode jogar: "rejeitar", retomando a PPP ou relicitando, levando a obtenção do mesmo payoff de falência (em termos de custos políticos). Caso adote a estratégia "negociar", o governo terá que analisar o fornecimento de subsídios $g U$ suficiente para cobertura do custo oportunista, que respeite a condição $m(g U)<n(G+\tau)$ onde $g U \geq G$, isto é, acatando as regiões limítrofes da ZOR. Deste modo, a inserção das restrições de incentivos adiciona novas condições para se analisar os equilíbrios propostos pelo jogo de Ho.

Pela suposição de custos burocráticos no pedido renegociação $(\delta>0)$ com o governo, há preferência em pedir subsídios. Ou seja, não vale a pena para o investidor jogar "falir PPP" logo no primeiro movimento (exceto em condições econômicas adversas, i.e., choques cambiais, intervenção governamental, etc.). Logo, $\theta_{L}$ ao fazer esforço oportunista $\hat{e}_{L}$, pede uma quantidade de subsídios $\$ U$ que deve cobrir a distância gerada entre $\hat{e}_{L}$ e $e_{L}^{*}$. Isto é, a quantidade mínima de subsídios pedida por $\theta_{L}$ é dada por:

$$
\$ U \geq \hat{e}_{L}-e_{L}^{*}
$$

Se o governo optar por renegociar, ele realiza contraoferta $g U$ ao investidor. Contudo, distingue-se do intervalo original de Ho. Para o limite inferior de $g$, adotamos a sentença estrita e o novo intervalo é definido por $0<g \leq 1$. Este intervalo tem a vantagem de evitar múltiplos ENPS. Assim, se $g=1$, o governo fornece para $\theta_{L}$ a quantidade máxima $\$ U$ e este subsídio deve respeitar a equação (9). No entanto, a distância originada pelo esforço oportunista e a equação (22) mostram que mesmo o governo que faça contraoferta $g=1$, tal condição pode não ser suficiente para cobrir o custo oportunista de $\theta_{L}$. Ao supor que $g=1$ não seja suficiente, a exigência de subsídios para $\theta_{L}$ torna-se a sentença estrita:

$$
\$ U>\hat{e}_{L}-e_{L}^{*}
$$


Logo, a diferença $\hat{e}_{L}-e_{L}^{*}$ não seria coberta e o governo se depara com custos políticos de renegociação maiores do que os da relicitação da PPP. Neste caso, a rejeição do governo em renegociar subsídios advém da revelação ex-post da baixa capacidade gerencial do investidor. Ou seja, seria imposta a condição de equilíbrio de não-resgate, mudando o equilíbrio do jogo.

Sobre a base do jogo original de Ho, a equação (22) demonstra, também, que a capacidade gerencial do investidor $\theta_{L}$, revelada somente no período de renegociação, se torna uma desvantagem informacional para o governo. Tal desvantagem determina uma posição fraca para o governo negociar subsídios, dado que a condição de equilíbrio de resgate $m(g U)<n(G+\tau)$ não se mantém, alterando o ENPS original do jogo.

As relações expostas evidenciam a consequência da tardia revelação da informação sobre a capacidade gerencial do investidor para o governo. Torna-se necessário, portanto, através a inserção de mecanismo de incentivos, estabelecer e avaliar as novas condições do equilíbrio de resgate expostos pelas equações (20) e (21) e como as funções de incentivos podem contribuir para aprimorar o jogo modelado por Ho (2006) em condições de assimetria. O modelo de renegociação de Ho mostra que o principal problema para o governo numa renegociação é a correta utilização da quantidade de subsídios. Dada escassez de recursos públicos, o uso de subsídios deve acarretar no menor custo político possível. As condições de ENPS determinam que a forma do governo mitigar esse problema é renegociar subsídios justificáveis. Isto é, o custo de renegociação seja menor do que retomar o projeto ou relicitá-lo a outro investidor.

O problema adicional à renegociação, levantando por este estudo, é mediante a posição informacional desvantajosa do governo em suas ações. O conhecimento tardio às necessidades de subsídios do investidor e sua capacidade gerencial, pode ser fator determinante para as frequências e volumes financeiros negociados nestas circunstâncias. Assim sendo, discute-se como a condição de equilíbrio de resgate do jogo de renegociação pode ser sustentada e reforçada, posto que os agentes revelem a verdade sobre seu tipo na fase de concorrência do contrato da PPP. 
A equação (22) define através de $\$ U \geq \hat{e}_{L}-e_{L}^{*}$, que a cobertura entre o esforço realizado $\hat{e}_{L}$ e o esforço suportado $e_{L}^{*}$ pode não ocorrer se a necessidades de subsídios de $\theta_{L}$ forem maiores que $\$ U$. Tal ocorrência significa que o governo deveria, na contrapartida, fornecer $g>1$ o que é não factível com os limites de orçamento justificável de subsídios. Além disso, como $U$ é a quantidade máxima de subsídios da renegociação, pode-se alterar a condição de compensação. Para tal, impõe-se que o governo jamais oferece a contrapartida máxima de subsídios, o que constitui estritamente que $g<1$. A conjectura 1 auxilia nesta definição:

Conjectura 1: O governo evita o oferecimento da contrapartida máxima $g=1$ no jogo de renegociação. O que estabelece as condições:

$$
g=\left\{\begin{array}{l}
\text { Se } U>\hat{e}_{L}-e_{L}^{*} \rightarrow g>1 \\
\text { Se } U=\hat{e}_{L}-e_{L}^{*} \rightarrow g=1
\end{array}\right.
$$

Portanto, a conjectura 1 sugere que o governo teria grandes dificuldades em negociar subsídios com $\theta_{L}$. Esta conjectura exclui o caso em que a continuidade PPP original é tão importante que o governo prefere pagar um alto subsídio a $\theta_{L}$ do que parar o PPP para um novo processo de licitação. Assim, um contrato que detenha as restrições de incentivos e respeita o imposto pela conjectura 1, altera o intervalo da contrapartida $g U$ no jogo de renegociação para $0<g \leq 1$. O lema 3 ajuda a construir esta alteração.

Lema 3: Posto que o pedido de subsídios de $\theta_{L}$ corresponde a sentença $\$ U \geq \hat{e}_{L}-e_{L}^{*}$, quantidade de subsídios $\$ U$, jamais consegue cobrir a diferença, respectivamente, entre esforço oportunista realizado e o suportado $\hat{e}_{L}-e_{L}^{*}$.

Prova: Se $\$ U$ sempre cobrir a diferença oportunista $\hat{e}_{L}-e_{L}^{*}$ ter-se-ia condição $\$ U=\hat{e}_{L}-e_{L}^{*}$, implicando para todo cenário de renegociação, no mínimo, $g=1$. Se o governo sempre inicia a condição de negociação com $g=1$, significa que o principal não detém margem negociável, se tornando indiferente em desenhar um contrato de equilíbrio separador que respeite o Lema 1 e a ZOR.

Portanto, se o governo realiza a renegociação $\operatorname{com} \theta_{L}$, o Lema 3 impõe que a quantidade compensatória de subsídios não garante satisfazer as necessidades do investidor de baixa produtividade. 
A modificação do intervalo original $0 \leq g \leq 1$ pelo intervalo $0<g \leq 1$, colabora para afirmação que o governo sempre terá margem para renegociar. As condições exibidas para o investidor de baixa produtividade contribuem para dois insights: (i) edital de licitação com falhas de triagem, selecionando investidores ineficientes praticando bid oportunista (oportunismo ex-ante); (ii) consequentemente, o oportunismo ex-post ocorre, ou seja, esforço acima da capacidade gerencial, onde o investidor ineficiente tenta recuperar suas perdas na renegociação com o governo. Se a renegociação é feita com o investidor $\theta_{L}$, a alocação de subsídios na PPP é excessiva, devido a pouca margem de contrapartida inicial do governo.

\section{3 \\ Formação do ENPS Bayesiano na renegociação}

O tópico anterior exibiu uma sequencia de lemas aliadas a uma conjectura que formam a equação (22). Demonstrou-se que o jogo original de Ho, não abrange a questão sobre qual tipo de investidor renegocia subsídios com o governo. Um dos problemas levantado neste capítulo é que o governo, tardiamente, tem a revelação de que joga com o investidor $\theta_{L}$. Tal informação é revelada pelo pedido frequente de renegociações ou de subsídios excessivos. Além do mais, independente de o edital possuir ou não mecanismos de incentivos para triagem de investidores, o governo prefere uma PPP que tenha a participação de $\theta_{H}$ em detrimento a $\theta_{L}$. Neste sentido, um contrato com incentivos pode criar condições para que as renegociações não tenham um custo político elevado, indo ao encontro da preferencia do governo por $\theta_{H}$.

Como $\$ U \geq \hat{e}_{L}-e_{L}^{*}$ não acata, satisfatoriamente, as condições dos lemas 2 e 3, logo, a ação estratégica de $\theta_{L}$ é rejeitar o volume de subsídios $g U$ fornecidos, tendo o governo que retomar ou relicitar a PPP. Isto é, negociar com $\theta_{L}$, torna os custos políticos da renegociação superiores ao de relicitação, ultrapassando $J$, e consequentemente o limite superior $g U \leq m^{-1}[n(G+\tau)]$. Logo, constroem-se, através do Teorema de Renegociação de PPPs, tais condições. 
Teorema de Renegociação de PPPs 1: Um contrato de PPP que não detenha as restrições de incentivos $R_{H}-c\left(e_{H}, \theta_{H}\right) \geq R_{L}-c\left(e_{L}, \theta_{H}\right)$ e $R_{L}-$ $c\left(e_{L}, \theta_{L}\right) \geq R_{H}-c\left(e_{H}, \theta_{L}\right)$, permite a seleção do agente $\theta_{L}$. Devido à condição de esforço incompatível, o agente negocia subsídios $U \geq \hat{e}_{L}-e_{L}^{*}$ que, no entanto, não respeitam o limite $g U \leq m^{-1}[n(G+\tau)]$. Posto que o Principal realiza a contrapartida crível $g \leq 1$, o investidor $\theta_{L}$ rejeita $g U$.

Prova: Se o governo não condiciona no contrato de PPP, as restrições $(9 c)$ e $(9 d)$, fica sujeito a revelação do estado $\theta_{i}$ somente na renegociação. Caso o intervalo original $0 \leq g \leq 1$ fosse mantido e dada a assimetria de informação quanto ao tipo $\theta_{L}$, o governo joga compulsoriamente $g=1$, ficando sem margem na renegociação. Adicionalmente, a sentença $\$ U \geq \hat{e}_{L}-e_{L}^{*}$ que impõe, no mínimo, $g=1$, pode não garantir a condição satisfatória do esforço oportunista de $\theta_{L}$. Tal situação expõe que $g>1$ satisfaria $\theta_{L}$, entretanto, gerando $g U \geq m^{-1}[n(G+\tau)]$. Consequentemente, se o governo não respeita o limite da ZOR, quebra-se o equilíbrio de resgate $m(g U)<n(G+\tau)$. Portanto, não compensaria gerar um contrato com equilíbrio separador, conforme o Lema 1 tal que $c_{e}\left(e, \theta_{j}\right)>$ $c_{e}\left(e, \theta_{i}\right)$ para $i \neq j$.

O Teorema de Renegociação 1 volta-se, especificamente, para as considerações feitas para o agente de baixa capacidade. Em um contrato sem restrições de incentivos, tanto o governo quanto $\theta_{L}$ detém pouco poder de negociação. Sua incapacidade no gerenciamento de custos, o coloca em um cenário que qualquer contraoferta que não seja ao menos $g=1$, o conduz a rejeitar $g U$.

O novo intervalo $0<g \leq 1$ proposto, torna-se conveniente, também, quando o governo joga com o investidor $\theta_{H}$. Se $\theta_{H}$ estima que a contraoferta $g \leq 1$ do governo é crível, logo, sabe que não poderá realizar um mau gerenciamento de custos, uma vez que não conseguirá a quantidade máxima de subsídios $\$ U$ na renegociação. A sentença $g \leq 1$, não impede que $\theta_{H}$ peça $\$ U$, porém, o investidor estima que o governo não acatará o pedido máximo de subsídios. Deste modo, o intervalo $0<g \leq 1$ em uma renegociação, colabora e reforça as condições ex-ante das restrições de incentivos.

Por outro lado, as condições que fazem $\theta_{H}$ pedir subsídios são diferentes das solicitações de $\theta_{L}$ (oriundas do bid oportunista). O investidor $\theta_{H}$ solicita 
subsídios para o governo, em duas situações: (i) caso haja um choque adverso na economia (desvalorizações cambiais excessivas, mudanças abruptas na formulação de política econômica, aceleração inflacionária diminuindo a taxa de retorno do projeto, etc); (ii) oportunismo do governo via expropriação de receitas. Nessa situação, mesmo um elevado volume de subsídio é justificável, como previsto em Ho (2006), por não se tratar de má gestão. Dada a preferencia do governo por $\theta_{H}$, parte-se da premissa que o investidor de alta capacidade mantém o ENPS de resgate $m(g U) \leq n(G+\tau)$. A conjectura 2 apresentada a seguir auxilia da construção deste cenário.

Conjectura 2: $\mathrm{O}$ agente $\theta_{H}$ solicita renegociação para o governo, somente por duas condições: (i) choques econômicos adversos ou; (ii) expropriação de receitas/ativos por parte do governo. Esta solicitação mantém os subsídios justificáveis $J$ que respeitam o limite superior $g U \leq m^{-1}[n(G+\tau)]$ da ZOR.

Assim sendo, as condições do Lema 1 reforçam a conjectura 2 para o âmbito da renegociação. O Teorema de Renegociação de PPPs 2, mostra que é sempre preferível para o governo, conduzir possíveis renegociações do projeto com $\theta_{H}$, pois este investidor mantém a condição de equilíbrio de resgate da equação (20).

Teorema de Renegociação de PPPs 2: Um contrato de PPP que detenha a restrição de incentivos $R_{H}-c\left(e_{H}, \theta_{H}\right) \geq R_{L}-c\left(e_{L}, \theta_{H}\right)$ e $R_{L}-c\left(e_{L}, \theta_{L}\right) \geq R_{H}-$ $c\left(e_{H}, \theta_{L}\right)$, permite a seleção do agente $\theta_{H}$. Este agente, sabe que o principal atua na renegociação atribuindo o intervalo crível $0<g \leq 1$ que respeita o limite $g U \leq$ $m^{-1}[n(G+\tau)]$, mantendo sua condição de esforço sustentável $e_{H}^{*}$. Dado que o principal realiza contrapartida crível, o investidor $\theta_{H}$ jamais rejeita a oferta de subsídios $g U$.

Prova: Se o intervalo original $0 \leq g \leq 1$ é mantido, o investidor $\theta_{H}$ poderia realizar a redução de esforço atuando de modo oportunista $e_{H}^{*}-\hat{e}_{H}$, quebrando a proposição 4 . A redução de esforço implica que $\theta_{H}$ peça volumes de subsídios maiores em futura renegociação, estimando que o governo possa realizar a contrapartida máxima $g=1$, mesmo em casos de ineficiência gerencial. No entanto, ao se admitir que $\theta_{H}$ possa realizar um esforço oportunista, consequentemente, as restrições de incentivos (9c) e (9d) não estão presentes no 
contrato inicial ou não são atendidas. Logo, o contrato desenhado não gera um equilíbrio separador e a contraoferta do governo não seria crível

Os teoremas de renegociação implicam que o jogo de renegociação de PPPs modelado por Ho (2006) tem seu equilíbrio alterado, caso as características do contrato inicial não realizem a seleção correta do investidor. Ou seja, se o contrato inicial não incentiva diretamente a participação de $\theta_{H}$, o governo fica sujeito a ter seus custos políticos de renegociação aumentados, devido a subsídios excessivos que se fazem necessários para manter o investidor original da PPP. Se o contrato não extrai a informação ex-ante sobre o tipo de investidor, as condições matemáticas sugeridas pelo equilíbrio de resgate não são mantidas.

A realização do estado da natureza $\theta_{i}$ no momento da solicitação de subsídios faz com que a contrapartida $g U$ seja o único mecanismo de revelação informativo sobre a produtividade ou tipo do investidor. Porém, o estado $\theta_{i}$ é revelado tardiamente ao governo. Assim sendo, o intervalo $0 \leq g \leq 1$ não garante, suficientemente, que o equilíbrio de resgate $m(g U) \leq n(G+\tau)$ seja mantido caso o investidor revelado na renegociação seja $\theta_{L}$. O novo intervalo crível $0<g \leq 1$, além de garantir margem na contraoferta do governo, faz com que não haja um $g$ significativamente elevado para que $\theta_{L}$ aceite continuar na PPP sem as condições produtivas necessárias ao projeto. Portanto, sem restrições de incentivos, o governo escolhe uma taxa $g$ que tardiamente revela o estado $\theta_{i}$. Deste modo, para cada estado $\theta_{i}$, que se revela somente na renegociação, tem-se um custo associado. As sentenças descritas pela equação (25) na sequência descrevem o custo associado a cada estado:

$$
\theta_{i}=\left\{\begin{array}{c}
i=L \rightarrow C \theta_{L}=\hat{e}_{L}-e_{L}^{*} \\
i=H \rightarrow C \theta_{H}=e_{H}^{*}-\hat{e}_{H} \\
C \theta_{H}<C \theta_{L}
\end{array}\right.
$$

Se o estado relevado tardiamente é o de baixa capacidade, então, $\theta_{L}$, ao realizar esforço oportunista, tem o custo imposto pela sentença $C \theta_{L}=\hat{e}_{L}-e_{L}^{*}$. Se o estado relevado tardiamente é o de alta capacidade, então, $\theta_{H}$, ao realizar esforço oportunista, tem a sentença $C \theta_{H}=e_{H}^{*}-\hat{e}_{H}$. Portanto, três observações são feitas sobre as condições determinadas em (25): (i) no estado $\theta_{L}$, o investidor está sempre 
realizando esforço acima de sua capacidade; (ii) No estado $\theta_{H}$, oportunismo se dá pela diminuição de esforço a priori (contrato inicial sem incentivos $e_{H}^{*}=e_{H}$ ) ou pelo oportunismo do governo ao expropriar receitas do projeto, estimulando $\theta_{H} \mathrm{em}$ cometer redução de esforço e. (iii) o oportunismo mais caro para o governo em termos de custo político sempre é gerado por um investidor ineficiente, então a frase $C \theta_{H}<C \theta_{L}$. Consequentemente, conduzindo o governo a oferecer uma taxa $g$ elevada. Logo, existe uma taxa ótima de $g$ na renegociação, que mantém o ENPS de resgate $m(g U)<n(G+\tau)$. Na revelação tardia, não é ótimo para o investidor $\theta_{L}$ e governo manterem a PPP ativa.

Portanto, define-se $g_{i}^{*}=\left(-\delta-C \theta_{i}\right) / \$ U$, como a taxa ótima de contraoferta do governo para o investidor que mantém o equilíbrio de resgate. Financeiramente, $g_{i}^{*}$ é o break-even point para o investidor que executa práticas eficientes de gerenciamento de projetos e mantém o valor presente líquido (VPL) da PPP inalterado. O valor ótimo de $g$ respeita o intervalo credível $0<g \leq 1$ que satisfaz o limite superior $g U \geq m^{-1}[n(G+\tau)]$. A definição de $g_{i}^{*}$ auxilia no entendimento das consequências da renegociação relativa a cada estado $\theta_{i}$ e, como o governo responde em suas contraofertas em cada situação.

Para demonstrar as condições expostas acima, a figura 17, na sequência, apresenta o modelo de renegociação de Ho (2006) modificado através da árvore Bayesiana de informação oculta. São adicionados, pela implementação dos dois teoremas de renegociação de PPPs propostos, os ENPS Bayesianos para cada estado $\theta_{i}$ revelado na renegociação.

O jogo se inicia com a natureza jogando. A linha tracejada determina a assimetria sobre o estado da natureza $\theta_{i}$ para o governo. As linhas duplicadas exibem o ENPS para cada estado do jogo. O lado direito da árvore mostra as condições na renegociação se o investidor é do tipo $\theta_{L}$. Este pode falir a PPP ou fazer um pedido de subsídios $\$ U$. Na sequência do jogo, dado o intervalo crível $0<g \leq 1$, o governo pode rejeitar a renegociação, gerando o payoff $[-\delta ;-n(B)]$. Caso contrário, dado que $\theta_{L}$ realiza um esforço oportunista, seu pedido de subsídios $U \geq \hat{e}_{L}-e_{L}^{*}$ deve cobrir os custos para manutenção da viabilidade financeira do projeto. O teorema de renegociação de PPPs 1 aliado ao intervalo $0<g \leq 1$, mostra que a necessidade de subsídios para $\theta_{L}$ não é satisfeita, porque o governo não ultrapassa os limites econômicos $g U \geq m^{-1}[n(G+\tau)]$, que resultam em 
custos políticos excessivos de renegociação. À medida que a contraoferta do governo é crível, $\theta_{L}$ rejeita a oferta de subsídios do governo, resultando no payoff de não aceitação $\left[-\delta-C \theta_{L} ;-n(B)\right]$ para investidor e governo, respectivamente. Pode-se questionar por que $\theta_{L}$ não aceita os subsídios, pois pode receber $g^{*} U$. No entanto, o investidor ineficiente percebe que $g^{*}$ é inferior às suas necessidades econômicas (break-even) e para evitar perdas futuras, o investidor prefere não permanecer no PPP. Assim, $\left[g^{*} U-C \theta_{L}-\delta ;-m(g U)\right]$ mostra que esta recompensa não é viável tanto para $\theta_{L}$ quanto para o governo.

$\mathrm{O}$ lado esquerdo da árvore bayesiana exibe o estado $\theta_{H}$. Da mesma forma, o investidor pode jogar pela falência do PPP (payoff $[0 ;-n(B)]$ ou solicitar subsídios $\$ U$. Na ação sequencial, o governo pode jogar rejeitar, realizando payoff $[-\delta ;-n(B)]$. Pelo ramo direito, o governo desempenha contraoferta $g U$ tal que $0<g \leq 1$. Dadas as condições do teorema de renegociação 2, $\theta_{H}$ aceita a contraoferta $g U$ do governo, resultando no payoff viável $\left[g^{*} U-C \theta_{H}-\right.$ $\delta ;-m(g U)]$. Para o investidor eficiente, $g^{*}$ satisfaz financeiramente o ponto de equilíbrio e possibilita sua manutenção na gestão do PPP. Pelas premissas impostas, $C \theta_{H}$ é um volume de subsídios justificáveis pelo governo $(J$ ) (ou seja, legalmente aprovado por um tribunal contábil), mesmo que $C \theta_{H}$ seja oriundo da adversidade. A taxa ótima $g^{*}$ também mostra: (i) que break-even é significativamente diferente entre os investidores $\theta_{H}$ e $\theta_{L}$ e reforçam a sentença $C \theta_{H}<C \theta_{L}$ da equação (24) e; (ii) reforça a condição de que o montante de subsídios solicitados não exceda o limite dos custos políticos suportados pelo governo para manter o atual contrato ativo.

Para determinar o ENPS Bayesiano, é necessário o procedimento de backward induction. A partir da definição de que $g^{*}$ é a taxa ótima de subsídios para manter o break-even do investidor eficiente, podemos analisar os payoffs a partir do final da árvore Bayesiana. Pela equação (24), o investidor $\theta_{H}$ joga aceitar a contraoferta do governo porque o payoff de aceitação é maior do que de não aceitação. A partir deste ponto, o governo verifica que o retorno da renegociação é superior ao da rejeição e concorda em negociar com o investidor tal que $m(g U)<$ $n(B)$. Finalmente, retornando ao nó inicial da árvore, a melhor estratégia para o investidor $\theta_{H}$ é exigir subsídios. 


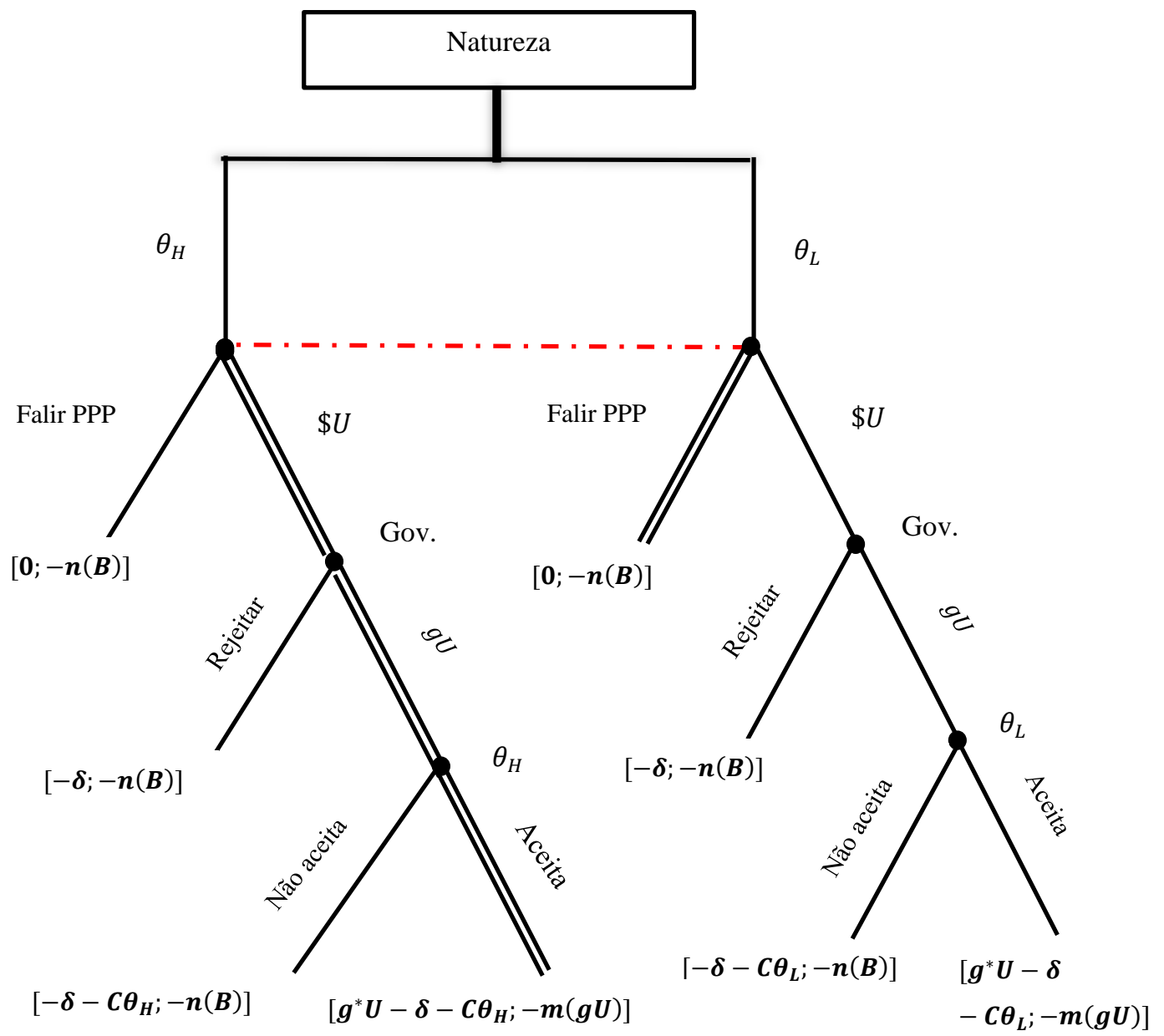

Figura 17 - Jogo de Ho com ENPS Bayesiano

Ao analisar os nós terminais da árvore do jogo para o investidor $\theta_{L}$, o payoff de não aceitação é menor que de aceitação, pois, $g^{*}$ não permite que o investidor ineficiente mantenha a saúde financeira da PPP. Do ponto de vista do governo, pode-se ver que o custo político de rejeitar a negociação é mais flexível e a melhor estratégia para o governo é renegociar. Retornando ao nó inicial da árvore, percebese que o melhor resultado estratégico para o investidor $\theta_{L}$ é decretar a falência do PPP. Para ambos os casos, a linha duplicada mostra o ENPS Bayesiano de renegociação. Os resultados do jogo de renegociação de Ho com informação assimétrica mostram que a ausência de restrições de incentivos no contrato de PPP, tem como único mecanismo de revelação à capacidade de gerenciamento do investidor dado por $g^{*}$. O obstáculo deste mecanismo é que a revelação do estado $\theta_{i}$ só ocorre na fase de renegociação. Neste período, o governo fica sujeito a menor margem na contrapartida de subsídios, especialmente se o estado revelado for $\theta_{L}$. 
Este investidor realiza um esforço oportunista que aumenta significativamente o custo de renegociação, consequentemente, resultando no equilíbrio de não resgate dado por $m(g U)>n(G+\tau)$. Sendo assim, uma taxa $g^{*}$ que gere incentivos para que $\theta_{L}$ se mantenha no projeto.

\section{4 . Renegociação do Complexo Maracanã}

A rodada de renegociação contratual é a fase onde se tornam mais evidentes a interação dinâmica entre governo e investidor. A seção 4.1 mostrou o contexto da abertura de renegociação do complexo Maracanã. A renegociação é motivada quando o GERJ impede que a concessionária Maracanã S.A realize a demolição de edificações presentes no complexo. O objetivo seria a construção de um shopping e um estacionamento vertical. A consequência da expropriação do governo de receitas/ativo do projeto impulsiona o investidor a atuar oportunisticamente. Em renegociação, a concessionária exige que as obrigações de investimento sejam reduzidas em proporção maior do que sua eventual perda de receitas, como sugerido pela proposição 3. O custo político do GERJ aumenta substancialmente, devido a pressões sociais e a proximidade do evento olímpico no Rio de Janeiro. As pressões sobre o GERJ o conduzem a reduzir as obrigações de investimento da Maracanã S.A que, na prática, funcionam como um subsídio indireto.

O anúncio da concessão do complexo Maracanã não tem nenhum mecanismo de incentivo para a triagem correta dos investidores. O GERJ, portanto, não possui informações suficientes sobre a capacidade de gerenciamento do licitante vencedor. As falhas contratuais deste caso geraram inúmeras críticas para o GERJ, para manter o contrato ativo com investidores que não melhorou o desempenho na prestação de serviços e no uso do Complexo Maracanã. Desde o final de 2016, mesmo após condições favoráveis na renegociação, a concessionária Maracanã S.A. sinalizou com a rescisão do contrato devido a dificuldades financeiras. A Tabela 1 abaixo foi elaborada mostrando números da atividade principal do estádio, ou seja, jogos de futebol, cinco anos antes e cinco anos após o contrato PPP. Com exceção dos anos 2011 e 2012, em que o estádio fez 
construções para sediar a Copa do Mundo de futebol da FIFA (os dados para 2017* são o número de jogos de futebol previstos até o mês de outubro). Compararam-se o número de jogos anuais realizados antes e depois da concessão.

Tabela 1 - Performance do Complexo Maracanã

\begin{tabular}{|c|c|c|c|}
\hline & Anos & $\mathrm{N}^{\mathrm{o}}$ de Jogos & Média anual \\
\hline \multirow{5}{*}{ Antes da concessão } & 2007 & 90 & \multirow{5}{*}{74 jogos por ano } \\
\hline & 2008 & 83 & \\
\hline & 2009 & 76 & \\
\hline & 2010 & 47 & \\
\hline & $2011 / 12 *$ & 0 & \\
\hline \multirow{5}{*}{ Após a Concessão } & 2013 & 64 & \multirow{5}{*}{50,4 jogos por ano } \\
\hline & 2014 & 82 & \\
\hline & 2015 & 71 & \\
\hline & 2016 & 7 & \\
\hline & 2017 & $28 *$ & \\
\hline
\end{tabular}

Fontes: elaboração do autor, http://www.fimdejogo.com.br and footstats.com.br. *Jogos realizados até outubro de 2017; ** Paralização para obras da copa do mundo de 2014.

Os resultados comparativos mostram que a concessionária obteve piores resultados do que os anos anteriores à concessão do PPP, reduzindo a média anual de jogos de futebol. No entanto, esses dados não podem ser interpretados como uma gestão eficiente do setor público. O que realmente deve ser interpretado é a ineficiência do desenho no edital de licitação. Ou seja, a ausência de mecanismos eficientes para triagem de investidores gerou:

(i) custos políticos excessivos para o GERJ;

(ii) o resultado financeiro esperado pela concessionária não foi alcançado;

(iii) a eficiência no uso do estádio (resultado do bem-estar) não melhorou.

Portanto, pode-se perceber a principal diferença entre o que foi ilustrado pela teoria e a prática dos gerentes públicos. Embora a teoria dos jogos apresentada 
neste estudo recomende que o melhor retorno para o governo e o investidor ineficiente seja decretar a bancarrota do projeto e construir um novo edital de licitação, o caso ilustrativo mostra que isso nem sempre ocorre na prática pública. 


\section{7. \\ Conclusões}

\section{1}

\section{Análise e contribuições do estudo}

Este trabalho utilizou o modelo de contrato Agente-Principal com mecanismos de incentivos para mitigar o comportamento oportunista em PPPs. Para isto, o estudo foi separado em duas etapas: A primeira, através de um conjunto de proposições adaptadas do contrato de mercado de trabalho presentes em MasColell et al (1995). Na segunda fase, usaram-se as restrições de incentivos no jogo de renegociação de PPPs de Ho (2006), verificando como a escolha do tipo do investidor $\theta_{i}$ altera os payoffs de ENPS.

Para evidenciar as condições teóricas da primeira etapa, utilizou-se o processo de concessão do complexo do Maracanã como aplicação. Os exemplos são balizados, principalmente, pelas proposições 3 e 4 . Verificou-se que o edital da concessão do Maracanã, ao não possuir mecanismos de triagem de investidores, não conseguiu evitar prejuízos à viabilidade financeira da PPP. No primeiro exemplo de movimentos oportunistas, o GERJ inicia alterando as condições contratuais, expropriando receitas, gerando uma queda em torno de $43 \%$. Consequentemente, conduzindo a concessionária a atuar de modo oportunista na renegociação de contrato. A nova obrigatoriedade de investimentos a serem realizados decai em torno de 59\%. Portanto, a implicação de tais movimentos oportunistas, é que as despesas de investimento para a concessionária reduzem-se proporcionalmente mais do que sua queda nas receitas. No segundo exemplo, sugeriram-se duas situações pós-contratuais. A primeira situação oportunista acontece pelo fato do GERJ ter selecionado um agente $\theta_{L}$, que por não possuir condições gerenciais e financeiras, excede sua capacidade de esforço, não conseguindo cumprir seus compromissos contratuais. Na segunda situação, o contrato do GERJ não consegue extrair o esforço máximo do agente $\theta_{H}$ e este atua de modo oportunista para diminuir seu esforço, sabendo que a queda em suas receitas será proporcionalmente menor. 
A segunda etapa deste estudo utilizou mecanismos de incentivos no modelo de renegociação PPPs de Ho (2006). Partiu-se da premissa que a renegociação excessiva de subsídios é pedida pelo investidor $\theta_{L}$ que, no momento da licitação, realiza um bid superestimado. Entretanto, $\theta_{L}$ não detém capacidade gerencial suficiente para manter as condições financeiras e operacionais do projeto. Portanto, tem maior tendência em exigir subsídios inexequíveis ao governo após a celebração do contrato. Por conseguinte, os subsídios excessivos, desrespeitam os limites impostos pela Zona de Oferta de Renegociação, elevando os custos políticos para o governo de se manter a PPP com o investidor original.

Para estruturar a assimetria informacional no jogo de renegociação, foram propostos: duas conjecturas, três lemas e dois teoremas para renegociação de PPPs. A finalidade foi verificar como a produtividade do investidor interfere, diretamente, nos payoffs do jogo proposto por Ho (2006). Introduziram-se custos adicionais para pedidos de renegociação e o intervalo original para os subsídios na renegociação foi alterado. Impôs-se que o governo sempre oferece uma contraoferta menor do que o máximo de subsídios possíveis nas situações que não envolvem condições adversas durante o contrato. Este novo intervalo evita que o governo fique sem margem de renegociação, sendo este intervalo crível para ambos os jogadores.

A contribuição deste estudo foi demonstrar que a teoria de Desenho de Mecanismos pode aprimorar significativamente o desenho contratual de Parcerias Publico-Privadas. A implementação de mecanismos de incentivos, na fase incial do contrato (edital) fornece as seguintes melhorias: (i) pode-se aprimorar a triagem de investidores na PPP, evitando o bid oportunista; (ii) evitar que o investidor que ganhe a licitação diminua seu esforço, desempenhando o modo oportunista; (iii) ressalta como o oportunismo do governo, expropriando receitas, pode impulsionar o investidor a atuar oportunisticamente; (iv) a falta de mecanismos na triagem de investidores, pode prejudicar a margem de renegociação de ambas as partes e, adicionalmente, implicam em custos políticos maiores para o governo (consequências ex-post); (v) o resultado ótimo na renegociação para o investidor eficiente e governo é negociar e manter o contrato da PPP ativo e; (vi) no caso do investidor ineficiente, o melhor resultado é decretar diretamente a falência da PPP. 


\section{2 Implicações para a prática de políticas públicas}

Agentes públicos na América Latina raramente usam recursos de teoria de jogos para desenhar contratos para concessões de monopólios naturais. Isso resulta em uma alta taxa de renegociações e rescisão contratual nesses países. Como ressaltado, o estudo de Guash et al (2003), indica que mais de 40\% das concessões na América Latina foram renegociadas, particularmente no setor de transporte. A primeira rodada de renegociação ocorreu em média dois anos após a assinatura do contrato. Assim, este trabalho sugere que a teoria de desenho de mecanismos possa ser usada na prática das políticas públicas com maior frequência, com o objetivo de melhorar a triagem dos potenciais investidores. Os contratos de PPP que mantêm essa preocupação desde o início, com incentivos bem desenhados, geralmente selecionam um investidor com boa capacidade financeira e gerencial. Consequentemente, impactando no aumento do bem-estar social e evitando a descrença na relação contratual entre entidades públicas e privadas.

Para o setor público, a principal vantagem em modelar contratos de PPPs com mecanismos de incentivos é a criação de um sistema transparente de classificação e seleção de investidores, em que será ótimo para o investidor ter um desempenho ex-post eficiente e alinhado com os objetivos públicos da PPP. O uso na prática deve selecionar de modo explícito os potenciais investidores de alta capacidade técnica, exigindo: (i) histórico de participação em projetos de PPP; (ii) Se o investidor já participa ou participou de PPPs, exigindo seu histórico no cumprimento de contratos; (iii) Definição da composição do equity como proporção da parte a ser financiada por dívida (Pantelias \& Zhang, 2010); (iv) Exibir sólidas garantias bancárias. (v) Em PPPs de infraestrutura (por exemplo, rodovias), demonstrar que seu know how tecnológico pode diminuir o tempo de viagem mantendo padrões de segurança veicular, etc. Sendo assim, há uma série de fatores que podem ser definidos para decantar a qualidade de investidores e respeitar as especificidades de cada PPP. Todos estes fatores são fundamentais para que o projeto cumpra a finalidade de prover serviços públicos de qualidade ao menor custo possível. Para o cumprimento destes objetivos, num contrato first-best para o setor público se deve selecionar agentes que reúnam tais características. Cláusulas contratuais bem definidas podem minimizar o oportunismo de ambos os jogadores. 
Deste modo, futuras possíveis renegociações podem ser minimizadas ou aprimoradas, acarretando em menores custos políticos posto por: (i) subsídios justificáveis para tribunais de contas, (ii) maior transparência no uso de recursos públicos e, principalmente; (iii) segurança jurídica para o investidor aliada a manutenção de taxas de retorno adequadas para PPP.

\section{3 \\ Limitações e pesquisas futuras}

O uso do modelo de caráter estático usado nos capítulos 2 e 3 estão entre as limitações deste estudo, por não capturar todas as interações dinâmicas que podem ocorrer entre agentes públicos e privados durante a vida do contrato. Todavia, pode auxiliar o setor público no desenho de incentivos contratuais, selecionando adequadamente investidores durante o processo de licitação e reduzindo as implicações do oportunismo (ex-post). A relação dinâmica entre governo e investidor é mais evidente em períodos de renegociação contratual. Nesta fase, a renegociação ocorre para indicar novos parâmetros no contrato. Esta fase foi reportada neste estudo ao considerar assimetria de informação no modelo de Ho (2006). Os capítulos 5 e 6 demonstraram que o tipo produtivo do investidor pode alterar significativamente as condições de ENPS proposto pelo jogo de Ho.

A literatura de PPPs ainda apresenta incipientes estudos relacionando mecanismos de incentivos aos contratos de PPP. Contudo, outras vertentes de pesquisa aliadas à teoria dos jogos podem ser utilizadas, futuramente, para tratamento de melhorias contratuais. A Teoria de Opções Reais tem vasta literatura na aplicação de problemas em setores de infraestrutura (energia, rodoviário, ferroviário, aeroportos, etc). Geralmente, contratos ligados à área de infraestrutura são utilizados modelos de Parceria Público-Privada. No Brasil, a PPP do metrô da linha 4 na cidade de São Paulo utiliza um fomato de mecanismo, com limites superiores e inferiores, baseado no resultado das receitas efetivas de cada ano. As limites inferiores asseguram uma receita mínima ao investidor (ou seja, incentivo via garantias), funcionando como uma opção de venda (put). Limites superiores funcionam como uma opção de compra ( call). Neste contexto, pode-se pensar a call como um prêmio ao esforço do investidor na PPP em que parte da receita excedente 
do projeto é dividida com o governo. Maiores detalhes do modelo de GRMs pode ser encontrado em Brandão et al (2012). Deste modo, a GRM pode ser estudada como um incentivo adicional para atrair investidores que buscam minimizar potenciais riscos na PPP. Além disso, calls e puts presentes no contrato inicial (condição ex ante), podem funcionar como um mecanismo direto que impedem conflituosas e frequentes renegociações entre o setor público e privado.

Adicionalmente, a teoria de finanças públicas e os métodos econométricos (via séries temporais) podem acresentar contribuições em estudos futuros na literatura de PPPs. Pode se partir da premissa que cenários de déficits públicos elevados, conduzem governos a aumentar a oferta de projetos de PPP. A principal causa seriam as dificuldades orçamentárias em períodos imediatamente anteriores ao lançamento da concessão relacionando esta condição às renegociações ou rescisões de contratos frequentes. Consequentemente, governos que apresentam um quadro de dificuldade fiscal, desenham o edital de modo ineficiente (realização do processo com maior celeridade) resultando em um processo de concessão com valores subestimados com intuito de recuperar dificuldades do orçamento público. 


\section{8. \\ Referências bibliográficas}

ADRIAN, J. J. Construction claims: A quantitative approach, Stipes Publishing Co., Champaign, III. 1993

AURIOL, E., PICARD, P. M. A theory of BOT concession contracts. Journal of Economic Behavior \& Organization, v.89, 187-209, 2013.

BRANDÃO, L., SARAIVA, E. The option value of government guarantees in infrastructure projects. Construction Management \& Economics, v. 26, 1171-1180, 2008.

BRANDÃO, L.E., BASTIAN-PINTO, C., GOMES, L.L. and LABES, M. Government Supports in PPP Contracts: The Case of the Metro Line 4 of the São Paulo Subway System. Journal of Infrastructure Systems, v.18 (3), 218-225, 2012.

CHANG, C. Principal-Agent Model of Risk Allocation in Construction Contracts and its Critique. Journal of Construction Engineering and Management, v.140(1), 2014.

CRUZ, C.O., MARQUES, R. C. Exogenous Determinants for Renegotiating Public Infrastructure Concessions: Evidence from Portugal. Journal of Construction Engineering and Management, v.139 (9), 1082-1090, 2013.

DASPUGTA, P., HAMMOND, P. MASKIN, E. The Implementation of Social Choice Rules: Some Results on incentive compatibility. Review of Economic Studies.v.46, 185-216, 1979.

DEWATRIPONT, M., MASKIN, E. Contract Renegotiation in Models of Asymmetric Information. European Economic Review, v.34: 311-321, 1990.

ENGLMAIER. F., WAMBACH. A. Optimal incentive contracts under inequity aversion. Games and Economic Behavior, 2 (69): 312-328, 2010.

FUDENBERG, D. and TIROLE, J. Moral Hazard and Renegotiation in Agency Contracts. Econometrica, v.58(6), 1279-1319, 1990.

GIAMBIAGI, F., ALÉM, A.C. Finanças Públicas - Teoria e Prática no Brasil. 5ㅌ․ Ed. Campus, 2016.

Governo do Estado do Rio de Janeiro - Edital de Concorrência da Casa Civil. Disponível: http://www.rj.gov.br/web/casacivil/exibeconteudo?articleid=1457206. №03/2013. 2013. Acesso em 20 de Janeiro de 2016. 
GUASCH, J.L.. Renegotiation of concession contracts: a theoretical approach. Review of Industrial Organization, v.29(1), 55-73, 2006.

GUASCH, J.L., LAFFONT, J.J., STRAUB, S. Renegotiation of Concession Contracts in Latin America, World Bank Policy Research Working Paper 3011, Washington D.C., 2003.

GREGG, D.S. Parceria Público-Privada como alternativa para mitigar o problema de hold up em investimentos de infraestrutura no setor ferroviário: estudo de caso. Dissertação da Escola de Pós-Graduação em Economia - FGV/RJ, 2006.

HART, O., MOORE, J. Incomplete Contracts and Renegotiation. Econometrica, v. 56(4), 755-785, 1988.

HO, S.P. Model for Financial Renegotiation in Public-Private Partnership Projects and Its Policy Implications: Game Theoretic View. Journal of Construction Engineering and Management, v.132 (7), 678-688, 2006.

HO, S.P. Government Policy on PPP Financial Issues: Bid Compensation and Financial Renegotiation. Chapter 15 in Policy, Finance \& Management for Public-Private Partnerships. Eds Akintola Akintoye and Matthias Beck, Wiley-Blackwell, Oxford, Blackwell Publishing Ltd. 2009.

HO, S.P., LIU, L. Analytical Model for Analyzing Construction Claims and Opportunistic Bidding. Journal of Construction Engineering and Management, v.130(1), 94-104, 2004.

HO S,P., TSUI, C. When are Public-Private Partnerships not an Appropriate Governance Structure? Case Study Evidence. Proceedings of Construction Research Congress, Banff, Canada, 2010.

HURWICZ, L. Optimality and informational efficiency in resource allocation processes, in Arrow, Karlin and Suppes (eds.), Mathematical Methods in the Social Sciences. Stanford University Press. 1960.

HURWICZ, L. The design of mechanisms for resource allocation, American Economic Review. Papers and Proceedings, v. 63, 1-30, 1973.

LAFFONT, J.J., TIROLE, J. Adverse Selection and Renegotiation in Procurement. Review of Economic Studies, v.75, 597-626, 1990.

LAFFONT, J.J., MARTIMORT, D. The Theory of Incentives: the Principal-Agent Model. Princeton University Press, 2002.

LEVIN, P. Construction Contract Claims, Changes and Dispute Resolution, 2nd Ed., ASCE, Reston, Va. 1998. 
MARQUES, R.C, BERG, S. Risks, Contracts and Private Sector Participation in Infrastructure. Journal of Construction Engineering and Management, v.137 (11), 925-932, 2011.

MAS-COLELL, A., WHINSTON,M.D., GREEN,J.R. Microeconomic Theory. Oxford University Press, 1995.

MEDDA, F. A game theory approach for the allocation of risks in transport public private partnerships. International Journal of Project Management, v.25, 213-218, 2007.

MOSZORO,M. Overcoming Opportunism in Public-Private Project Finance. Journal of Applied Corporate Finance, v.25, 89-96, 2013

MYERSON, R. B. Incentive Compatibility and the Bargaining Problem. Econometrica, 47: 61-74, 1979

MYERSON, R. B. Optimal Coordination Mechanisms in Generalized Principal - Agent Problems. Journal of Mathematical Economics, 10: 67 $-81,1982$.

PÁEZ-PÉREZ, D., M. SÁNCHEZ-SILVA,. A dynamic principal-agent framework for modeling the performance of infrastructure. European Journal of Operational Research, 254(2):576-594, 2016.

PAGE, F.H.. Mechanism design for general screening problems with moral hazard. Economic Theory, 2: 265-281, 1992.

PANTELIAS, A., \& ZHANG, Z. Methodological framework for evaluation of financial viability of public-private partnerships: Investment risk approach. Journal of Infrastructure Systems, 16(4), 241-250, 2010.

Project Management Institute. A guide to the project management body of knowledge (PMBOK ${ }^{\circledast}$ guide). Drexel Hill, PA: Author. 2000.

RASMUSEN, E. Games and information, Blackwell Publisher Inc., Malden, Mass. 2001.

ROTHSCHILD, M., and STIGLITZ, J.E.. Equilibrium in Competitive Markets: An Essay in the Economics of Imperfect Information. Quarterly Journal of Economics. 80:629-49, 1976.

SILVA NETO, D.C., CRUZ, C.O., RODRIGUES, F., SILVA, P. Bibliometric Analysis of PPP and PFI Literature: Overview of 25 Years of Research. Journal of Construction Engineering and Management. 142(10), 2016.

Sitio da British Broadcasting Corporation Brasil. Consórcio da empresa de Eike larga à frente na disputa pelo Maracanã. Disponível em: www.bbc.com/portuguese/noticias/2013/04/130416_maracana_tarde_mdb_ cq. Acesso em 29 Janeiro de 2016. 
THOMAS, S. Ng, WONG Y.M.W, WONG, J.M.W. Factors influencing the success of PPP at feasibility stage and a tripartite comparison study in Hong Kong. Habitat International, 36(4), 423-432, 2012

VARIAN, Hal R. Intermediate Microeconomics: a modern approach. Published by Scranton, Pennsylvania, U.S.A.: W W Norton \& Co Inc, $8^{\text {th }} \mathrm{Ed}$, 2010.

WANG,Y., LIU, J. Evaluation of the excess revenue sharing ratio in PPP projects using principal-agent models. International Journal of Project Management. v.33(6), 1317-1324, 2015.

XIONG, W., ZHAO, X., YUAN, J.F., LUO, S. Ex Post Risk Management in Public-Private Partnership Infrastructure Projects. Project Management Journal, v.48(3), 76-89, 2017.

ZHU, L., ZHAO, X., CHUA, D. K. H. Agent-based debt terms' bargaining model to improve negotiation inefficiency in PPP projects. Journal of Computing in Civil Engineering. v.30(6), 2016. 


\section{Apêndice 1 - Maximização do Governo com Restrições de Incentivos (adaptado de Mas-Colell, 1995)}

Problema de maximização do governo com restrições compatível com incentivos é dado por:

$$
\operatorname{Maximizar}_{R_{L}, e_{L} \geq 0} \lambda\left[W\left(e_{H}\right)-R_{H}\right]+(1-\lambda)\left[W\left(e_{L}\right)-R_{L}\right]
$$

Sujeito a:

$$
\begin{aligned}
& R_{L}-c\left(e_{L}, \theta_{L}\right) \geq f^{-1}(\bar{\pi}) \\
& R_{H}-c\left(e_{H}, \theta_{H}\right) \geq f^{-1}(\bar{\pi}) \\
& R_{H}-c\left(e_{H}, \theta_{H}\right) \geq R_{L}-c\left(e_{L}, \theta_{H}\right) \\
& R_{L}-c\left(e_{L}, \theta_{L}\right) \geq R_{H}-c\left(e_{H}, \theta_{L}\right)
\end{aligned}
$$

Usando o proposição 2 reconfigura-se o problema (9):

$$
\operatorname{Maximizar}_{R_{L}, e_{L} \geq 0} \lambda\left[W\left(e_{H}\right)-R_{H}\right]+(1-\lambda)\left[W\left(e_{L}\right)-R_{L}\right]
$$

S.R.

$$
\begin{aligned}
& R_{L}-c\left(e_{L}, \theta_{L}\right) \geq f^{-1}(\bar{\pi}) \\
& R_{H}-c\left(e_{H}, \theta_{H}\right) \geq R_{L}-c\left(e_{L}, \theta_{H}\right) \\
& R_{L}-c\left(e_{L}, \theta_{L}\right) \geq R_{H}-c\left(e_{H}, \theta_{L}\right)
\end{aligned}
$$

Descrevendo $\mathcal{L}$ como a função Lagrangeana e $\left(\gamma, \emptyset_{H}, \emptyset_{L}\right) \geq 0$ os o multiplicadores de Lagrange das restrições (9.a), (9.c) e (9.d) respectivamente, as condições de Kuhn - Tucker para este problema podem ser descritas como:

$$
\begin{aligned}
& \partial \mathcal{L} / \partial R_{H}: \quad-\lambda+\emptyset_{H}-\emptyset_{L}=0 \\
& \partial \mathcal{L} / \partial R_{L}: \quad-(1-\lambda)+\gamma \emptyset_{H}-\emptyset_{L}=0 \\
& \partial \mathcal{L} / \partial e_{H}: \quad \lambda W^{\prime}\left(e_{H}\right)-\emptyset_{H} c_{e}\left(e_{H}, \theta_{H}\right)+\emptyset_{L} c_{e}\left(e_{H}, \theta_{L}\right)\left\{\begin{array}{c}
\leq 0 \\
=0 \text { se } e_{H}>0
\end{array}\right.
\end{aligned}
$$


$\partial \mathcal{L} / \partial e_{L}:(1-\lambda) W^{\prime}\left(e_{L}\right)-\left(\lambda+\emptyset_{L}\right) c_{e}\left(e_{L}, \theta_{L}\right)+\emptyset_{H} c_{e}\left(e_{L}, \theta_{H}\right)\left\{\begin{array}{c}\leq 0 \\ =0 \text { se } e_{L}>0\end{array}\right.$

Além das condições complementares para relaxar as restrições (9.a), (9.c) e (9. d), vamos fragmentar a análise dessas condições em várias etapas.

Etapa 1: condição (9.1.1) implica que $\emptyset_{H}>0$. Assim, a restrição (9.c) impõe uma solução ótima.

Etapa 2: Adicionando as condições (9.1) e (9.2) isso implica que $\gamma=1$. Assim, a restrição (9.a) impõe uma solução ótima.

Etapa 3: Os esforços $\left(e_{H}, e_{L}\right) \gg 0$ são estritamente positivos. Para verificar isto, note que a condição (9.3) não pode ser mantida com $e_{H}=0$ porque $W^{\prime}(0)>0$ e $c_{e}\left(0, \theta_{i}\right)=0$ para $i=L, H$. A análise é similar para a condição (9.4) e esforço $e_{L}$.

Etapa 4: As três etapas acima implicam que $\emptyset_{L}=0$. Ao supor que isso não ocorra, $\emptyset_{L}>0$, a restrição (9.d) deve ser imposta e pode-se derivar uma contradição. Inicialmente, substitui-se $\emptyset_{H}$ nas condições (9.3) e (9.4) usando o fato que $\emptyset_{H}=$ $\emptyset_{L}+\lambda$ para a condição (9.1). Logo, ao usar as condições do esforço da etapa 3 , isto é, $\left(e_{H}, e_{L}\right) \gg 0$, pode-se reescrever as condições $(9.3)$ e (9.4):

$$
\lambda\left[W^{\prime}\left(e_{H}\right)-c_{e}\left(e_{H}, \theta_{H}\right)\right]+\emptyset_{L}\left[c_{e}\left(e_{H}, \theta_{L}\right)-c_{e}\left(e_{H}, \theta_{H}\right)\right]=0
$$

e

$$
(1-\lambda)\left[W^{\prime}\left(e_{L}\right)-c_{e}\left(e_{L}, \theta_{H}\right)\right]+\left(1+\emptyset_{L}\right)\left[c_{e}\left(e_{L}, \theta_{H}\right)-c_{e}\left(e_{L}, \theta_{L}\right)=0\right.
$$

No entanto, $\emptyset_{L}>0$ implica que:

$$
W^{\prime}\left(e_{L}\right)-c_{e}\left(e_{L}, \theta_{H}\right)>0>W^{\prime}\left(e_{H}\right)-c_{e}\left(e_{H}, \theta_{H}\right)
$$

E implica que $e_{H}>e_{L}$ desde que $W(e)-c\left(e, \theta_{H}\right)$ seja côncava em $e$. Porém, se $e_{H}>e_{L}$ e está vinculada a restrição (9.c), então a restrição (9.d) deve ser relaxada pois, então, teremos:

$$
\left(R_{H}-R_{L}\right)=c\left(e_{H}, \theta_{H}\right)-c\left(e_{L}, \theta_{H}\right)
$$




$$
=\int_{e_{L}}^{e_{H}} c_{e}\left(e, \theta_{H}\right) d e<\int_{e_{L}}^{e_{H}} c_{e}\left(e, \theta_{L}\right) d e=c\left(e_{H}, \theta_{L}\right)-c\left(e_{L}, \theta_{L}\right)
$$

Que demonstra a contradição colocada acima.

Etapa 5: Dado que $\emptyset_{L}=0$, sabe-se de (9.1) que $\lambda=\emptyset_{H}$. Substituindo estes valores nas condições (9.3) e (9.4):

$$
W^{\prime}\left(e_{H}\right)-c_{e}\left(e_{H}, \theta_{H}\right)=0
$$

$\mathrm{e}$

$$
\left[W^{\prime}\left(e_{L}\right)-c_{e}\left(e_{L}, \theta_{L}\right)\right]+\frac{\lambda}{1-\lambda}\left[c_{e}\left(e_{L}, \theta_{H}\right)-c_{e}\left(e_{L}, \theta_{L}\right)\right]=0
$$

As condições (9.5) e (9.6) caracterizam os valores ótimos de $e_{H}$ e $e_{L}$, respectivamente. Os valores ótimos para $R_{H}$ e $R_{L}$ são então determinados pelas restrições (9. $c$ ) e (9.a), que mantém a igualdade na solução.

\section{Apêndice 2 - Características de Parâmetros da PPP de Ho (2006).}

- Característica 1. Pela definição de $G$, se o governo tem a intenção de resgatar um projeto, o subsídio para o projeto deve ser pelo menos igual a $G$, ou seja, $g U \geq G$.

- Característica 2. Considerando que ao substituir o desenvolvedor o custo de oportunidade é sempre positivo e significativo, ou seja, $\tau \geq 0$.

- Característica 3. Dado na Eq. 15 que $\beta$ e $\rho_{s}$ sejam funções estritamente crescentes, é simples ver que $m^{\prime}(x)>\beta^{\prime}(x)$ é verdade para todos $x \in(J, \infty)$, formalmente indicado como $x \in(J, \infty): m^{\prime}(x)>\beta^{\prime}(x)$ em que $m^{\prime}(x)$ e $\beta^{\prime}(x)$ são, respectivamente, as inclinações das funções $M$ e $\beta$.

- Característica 4. Uma vez que nem todas as perdas, devido à mudança de viabilidade financeira podem ser justificadas para oferecer subsídios durante a renegociação, o intervalo de $J$ pode ser modelado como:

$$
J \in[0, U]
$$


O montante de subsídio justificável depende de como o público pode concordar com o subsídio considerando razões justificáveis do investidor. Alternativamente, $J$ também pode ser determinado quantitativamente, devendo o pedido de subsídio ser levado a julgamento.

- Característica 5. De acordo com a regra do investimento do VPL, pode-se definir $G$ pela igualdade: $G+V P L_{t}=0$, o que significa que $G$ reverterá o VPL do projeto para zero. Esta característica vem da exigência de que $\mathrm{G}$ deve melhorar um projeto com $V P L_{t}$ negativo para zero. O VPL zero indica que o projeto tem lucro normal e vale a pena continuar para os desenvolvedores. 